\title{
THE 1989 NEWCASTLE, AUSTRALIA, EARTHQUAKE: THE FACTS AND THE MISCONCEPTIONS
}

\author{
J.M.W. Rynn', E. Brennan², P.R. Hughes 3 , I.S. Pedersen 4 \\ and H.J. Stuart ${ }^{5}$
}

\begin{abstract}
The vulnerability of urban environments in continental regions to earthquake forces was explicitly demonstrated in Australia's devastating Newcastle earthquake on December 28, 1989. This moderately-sized earthquake of Richter magnitude ML 5.6 (Moment magnitude M 5.3) claimed 13 lives, damaged more than 70,000 properties and left an estimated total loss of about $\$ A U(1991) 4$ billion. The need for an earthquake mitigation programme in Australia was thus clearly established. It is for this reason that a multidisciplinary approach involving seismology, geology, engineering,insurance, local government and emergency services is being followed to study this event and its consequences.
\end{abstract}

The earthquake source is defined as being on a thrust fault trending NW-SE dipping $75^{\circ}$ to the NE, with a depth of focus at $11.5 \mathrm{~km}$, source radius of $1.86 \mathrm{~km}$, stress drop of at least 24 bars and a displacement along the rupture surface of at least $310 \mathrm{~mm}$. The epicentre is located at $32.95^{\circ} \mathrm{S}, 151.61^{\circ} \mathrm{E}$ close to Boolaroo, about $15 \mathrm{~km} \mathrm{SW}$ of the City of Newcastle, and with an epicentral error of about $+15 \mathrm{~km}$. More than 100,000 observations from damage and felt reports are being analysed and integrated with the wide experiences gained in the rescue, recovery and renewal phases that have extended over the two years since the event.

The specific issue of the geotechnical aspects is of great importance. It is being considered from the view of urban geology (surface alluvial sediments), rather than from theoretical considerations, to explain the major extent of building damage on the alluvial areas, amplification and liquefaction. Apart from the immediate "causes" of damage, serious consideration is being given to the long-term effects which have resulted in the latent and recurrent defects to buildings. The engineering findings from the Newcastle earthquake are discussed in detail. While it is uneconomical and not necessary to design a structure to withstand the greatest likely earthquake without damage in Australia, the cost of providing strength to resist very high intensity loads must be weighed against the importance of the structure and probability of the earthquakes, particularly in areas such as this with relatively little known seismic histories. Lessons for local government authorities who had not previously considered seismic activity are addressed. Based on the response and recovery of the City of Newcastle, the lessons include the development of a recovery management plan, revision of building regulations and the requirements for hazard mitigation. Unfortunately, several misconceptions about some aspects of the consequences of this earthquake have arisen. These concern the limitations of some analyses, use of selected data sets rather than all the available data and apparent lack of understanding of complex, rather than singular, causal relationships. Implications for the engineering, insurance and possibly the legal professions need to be considered.

The potential to reduce losses in future earthquakes in Australia through an earthquake mitigation programme is now an achievable goal. The scenarios of such an event occurring at a different time or in a different city can be addressed, based on the Newcastle and other international experiences. Sufficient information is available to prepare the revised Australian earthquake loading code as a reliable and practical document for use by engineers. The consequences of the 1989 Newcastle earthquake have also captured the interest of researchers from many other continental areas of the Earth who must consider preparations for similar situations. All aspects of the study ultimately lead to the preparedness of urban communities to deal with such consequences with the assistance of emergency services agencies to minimize the social and economic traumas that will inevitably occur.

${ }^{1-5}$ The Centre for Earthquake Research in Australia [CERA], in association with The University of Queensland, Brisbane, Australia

1 Department of Geology and Mineralogy, The University of Queensland, Brisbane, Australia

2 Brennan and Associates, Consulting Geologists, Cleveland, Australia

3 Hughes McNaughton Pty Ltd, Consulting Engineers, Brisbane, Australia

4 Connel Wagner Rankine and Hill Group, Consulting Engineers, Newcastle, Australia

5 Director, Health and Building Services, Newcastle City Council, Newcastle, Australia 


\section{INTRODUCTION}

The 28 December 1989 Newcastle, Australia, earthquake, with moment magnitude M 5.3 and Richter Magnitude ML 5.6, was a stark reminder of the vulnerability of modern urbanised regions to devastating earthquakes - particularly in the context of continental regimes. The statistics of the impact of the Newcastle earthquake tell their own story: 13 lives lost; more than 165 persons seriously injured; a total felt area of more than $250,000 \mathrm{~km}^{2}$ including an approximate $20,000 \mathrm{~km}^{2}$ area within which property damage occurred (Modified Mercalli Scale of Intensity, MM > VI); more than 70,000 buildings within the affected area damaged; insurance losses of about \$AU(1991)1.2 billion; total estimated losses of about \$AU(1991)4 billion.

The consequences and lessons learnt from this earthquake for Australia, and indeed for the entire international community including both continental and plate margin regimes, are clearly apparent. Apart from the obvious and short term effects on the communities of Newcastle and its surrounds, continuing economic and social effects have beset these communities in the two years since the earthquake. These have particular relevance to effecting reliable and practical earthquake mitigation programmes for modern urbanised areas in the event of future disastrous earthquakes. Such concepts are in total accord with the United Nations global effort through the International Decade of Natural Disaster Reduction (IDNDR) [1]. For Australia, this program has commenced through the efforts of our organisation, CERA [2,3], and the Natural Disaster Organisation (NDO) of the Department of Defence, Commonwealth of Australia, Canberra [4], in a multidisciplinary approach integrating the earth sciences (seismology, geology, engineering (civil, structural, building services, geotechnical), insurance, sociology, government (Local, State, Federal), public education and disaster planning and management.

With the Newcastle experience as the catalyst, a review of the potential to reduce losses from earthquakes in Australia was presented at an Australian IDNDR seminar in 1991 [5]. This recognized the need to consult similar overseas (continental) situations, particularly that in the New Madrid area of the eastern USA [6]. Further consideration has since been given to other programmes in the USA, China and Europe. The common theme is related to the building stock, both current (aging buildings and critical facilities in our society and the lack of seismic design in the past) and future (inclusions of earthquake parameters in design criteria), particularly as it relates to the response and recovery phases following a serious earthquake and the planning for future earthquake occurrences.

In our case, the earthquake mitigation programme recently begun (by CERA,NDO and the Queensland State Emergency Service and Police Service) is considered essentially one of earthquake zonation for specific areas in eastern Australia in keeping with the current international directions [7]. It is thus essential that the totally available data set be analysed and subsequent con-clusions drawn from the results be carefully scrutinised before dissemination for community benefit.

\section{BACKGROUND}

Information on the immediate effects of this earthquake was efficiently gathered by the Institution of Engineers, Australia, and published in two comprehensive reports in early 1990 [8,9], the Newcastle City Council in relation to the local government response [10], the Bureau of Mineral Resources, Canberra, on the seismological aspects and instrumental coverage[11] (also in [8]) and the CSIRO, Australia, on building damage [12].

Immediately following the earthquake, a field survey to define the detailed macroseismic effects was initiated jointly by The University of Queensland and the Newcastle (New South Wales) Police Department. Earthquake Questionnaires were distributed throughout the State of New South Wales utilizing their Police Department resources, media outlets, local government authorities and community service organisations. The response to this from the general public yielded 30,000 reports. Contacts were made with other sectors, including the insurance industry, local government councils and shires and State Government agencies to obtain their damage reports. In all, more than 100,000 pieces of information were provided for this research study for collation and analysis. By mid-1990, preliminary results on a broad selection of this data (primarily macroseismic effects, geological controls on damage and some early lessons learnt from the event) were being made available to relevant governmental authorities $[13,14]$ and initial insurance industry summaries published $[15,16]$.

The latter half of 1990 saw the emergence of reports from governmental agencies and statutory bodies related to engineering damage and the economic and social effects of the earthquake on the worst affected area. These included, for example, damage and possible future problems to NSW State Government facilities [17,18], the Coronial Enquiry [19], economic effects [20], health effects [21] and other small reports on specific aspects of lifelines and emergency services. Such available information, in toto, was disseminated to those involved in disaster management in Australia (including emergency services, engineering, local government and insurance) through a conference held in November 1990 [2].

During this time, a concerted effort was made (and still continues today) to revise the Australian Earthquake Code AS2121-1979 [22]. New probabilistic earthquake risk maps were also published [23]. In the post-Newcastle studies, the question was raised as to whether Newcastle was a low risk area, as defined in [23]. Noting that the seismic risk maps were based solely on the earthquake record, the need to recognise the limitations of such an earthquake data set (only 200 years of record maximum in any one region, some of which is probably incomplete) and to include geology, tectonics and paleoseismicity as an integral part of any Code (as suggested in [24]), is clearly of importance. The requirements for such a Code revision, in terms of engineering design loads, have been appropriately discussed in relation to the pre- and postNewcastle situations $[25,26,27]$. Reference has specifically been made to the seismological input and resultant ground acceleration coefficients. The Draft Australian Standard revised Code was issued in April 1991 [28]. Considerable concern has been raised as to the practicality of the revised Code by members of CERA and discussions are still in progress (J. Woodside, G.Hutchinson; pers. comm.,1991). In particular, the assessment of risk and potential damage/deaths in higher population density areas in Australia has, to date, been ignored.

Research has continued through 1991 in a number of related aspects. The results have been directed towards practical actions applicable to the response, recovery and renewal phases following a future disastrous earthquake $[29,30,31,32]$. The status of all research findings, except for sociological aspects, were presented at a conference in October 1991 organised by the 
Newcastle City Council and CERA [3]. A summary based on these findings was presented at a special session of the Pacific Conference on Earthquake Engineering in New Zealand in November 1991 [33].

Each of these above resources has constituted a part of the overall data base. The macroseismic information then becomes the most valuable data source when there is a lack of instrumental data, which was the situation that existed for Newcastle.

This paper presents the current status of the study and of ongoing research into the 1989 Newcastle earthquake and implications for future mitigation of the earthquake hazard in continental regimes. The emphasis is strongly placed on the urbanised (highly populated and industrialised) areas. The "FACTS" are broadly classified as the observations and the questions raised, both of which are vital in preparing for such future earthquakes. The analyses are directed at considering damage assessment, geological controls on damage including ground amplification and the potential for liquefaction, and earthquake preparedness. The "MISCONCEPTIONS" arise from inferences placed on the interpretation of results, some of which have already caused concern in several quarters. Of particular note are studies that have used only selected parts of the total available data set to infer definitive causal relationships within geotechnical aspects $[34,35]$, studies to establish seismic vulnerability criteria for regions of (supposed) low seismicity [36] (based on [37]) and the preparation of earthquake codes which are now seen to be unrealistic in terms of the known situation. It is thus considered that there is a need to quantify the facts and the misconceptions, particularly in regard to the 1989 Newcastle earthquake.

\section{HISTORY OF NEWCASTLE REGION}

The Newcastle region (or Hunter Valley region) was discovered in 1797 and first settled in 1804. It has a history almost as long as the nation itself. The region has been built into one of the most important agricultural and industrial zones in Australia, well known for its coal mining developments and is a vital export port for Australia [38]. It supports a population in excess of 500,000, which includes several major population centres with the City of Newcastle as its regional centre, and thus maintains a very significant infrastructure. Newcastle, located on the central coast of New South Wales $115 \mathrm{~km}$ north of Sydney (Figure 1), is Australia's sixth largest city with a population of about 130,000. The building stock of the city (and indeed of the whole region and even Australia) is a blend of old and modern, with many fine examples of Australia's early architecture. The inner city urban areas (again similar for the whole region) are largely composed of older masonry (brick) buildings, many of which were erected on alluvial deposits.

The history of earthquake effects experienced in the region has been documented since the region's establishment, the earliest earthquake on record occurring in 1801 [39]. The effects of more than ten earthquakes had been reported prior to the 1989 earthquake. Two of these are of significance to Newcastle (Figure 1) : the June 12, 1868 "Maitland" earthquake, ML 5.3, caused severe damage to the town of Maitland and surrounding districts (MM VI - VIII) with some damage in Newcastle (MM VI)[11], and the December 18, 1925 "Boolaroo" earthquake, ML 5.3 [40], has striking similarities to the 1989 event. The latter is still vividly remembered by many older citizens of Newcastle and Lake Macquarie cities wherein serious damage
(MM VI - VII) was recorded. Considerable interest was manifested by the 1989 earthquake, resulting in many reports of several "tremors" in the few years preceding this event. Unfortunately, no instrumental confirmation of definite earthquakes was feasible as the nearest seismograph to Newcastle was about $100 \mathrm{~km}$ south of the region.

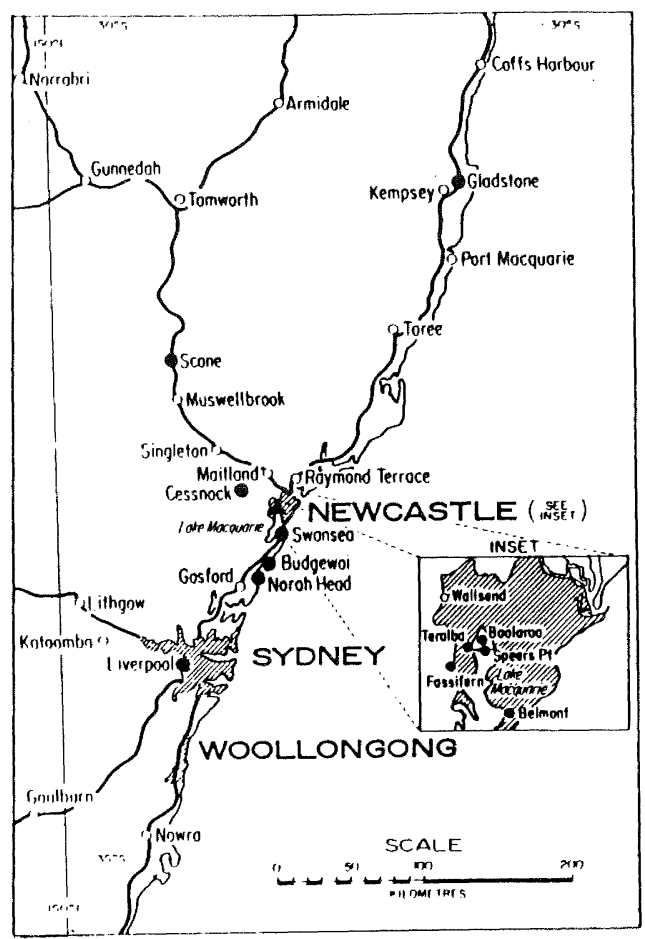

\section{FIGURE 1 LOCATION MAP OF NEWCASTLE, AUSTRALIA}

Since 1958, the Australian National University (ANU), Canberra, has operated the South East Australia seismograph network wherein the Newcastle region is on the northern fringe. More than 40 events have been located in the Hunter Valley region prior to the 1989 Newcastle earthquake (J. Weekes, B.Kennett; pers. comm., 1990). Many of these, however, are associated with coal mine blasting and other local quarry activities. Figure 2 shows the epicentres of known earthquakes, all probable manmade blasts having been removed from the data set. A detailed study of this historic seismicity has recently been completed [41].

Care must be taken when appraising this historic seismicity. While the effects of these earthquakes were indeed experienced in the region, their epicentres may not have been there. Two well known earthquakes can be cited in this context - 1961 "Robertson" ML 5.6 and 1973 "Picton" ML 5.5 -with epicentres 180-200 km south of Newcastle [42]. This does not, however, detract from the value of these historical records in defining the seismic risk necessary for earthquake code revisions and hazard mitigation [25]. 


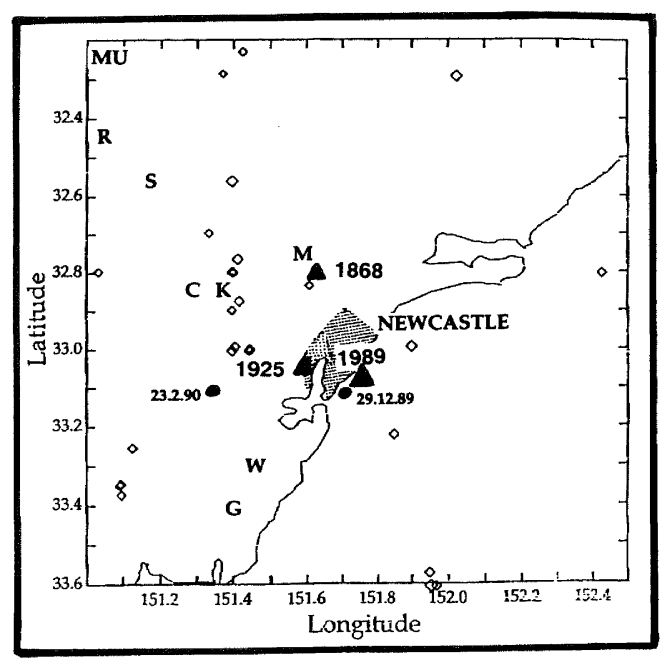

FIGURE 2 EPICENTRAL MAP FOR NEWCASTLE AND HUNTER RIVER VALLEY REGION EARTHQUAKES 1958 THROUGH 1990, WITH RICHTER MAGNITUDE ML 2.0 - 5.6. MAJOR EARTHQUAKES OF 1868, 1925 AND 1989 ARE SHOWN. EPICENTRAL ERRORS UP TO $+20 \mathrm{~km}$. ALL PROBABLE BLASTS OMITTED. BLASTING CENTRES ARE INDICATED (COAL MINES - MUMUSWELLBROOK; R RAVENSWORTH; S SINGLETON; M MAITLAND; C CESSNOCK; K KURRI KURRI : QUARRY AREAS - W WYONG; G GOSFORD). (FROM ANU DATA; WITH PERMISSION J. WEEKES, B.KENNETT,1990)

\section{SEISMOLOGY AND GEOLOGY}

\section{The Source:}

Based on the immediately available instrumental data, the published location was given by the Bureau of Mineral Resources, Canberra, [11] (also in [8,9]) as $32.95^{\circ} \mathrm{S}, 151.61^{\circ} \mathrm{E}$, close to Boolaroo about $15 \mathrm{~km}$ WSW of the Newcastle CBD (BMR : Figure 3 and Table 1). A depth of focus of $11.5 \mathrm{~km}$ was assigned based on the surface reflected seismic phases pPKIKP and pPKP recorded by seismographs of the Lownet Array in Scotland.

As more details of the damage have emerged since the earthquake, engineers have questioned the location of the earthquake in relation to reconciling the damage patterns observed. These include the directionality of (western) wall collapses, surface motion observations, effects in the Tasman Sea adjacent to the Newcastle coastal region, the widespread extent of damage and the geological controls (alluvial areas) on the damage.

To review this location question, several issues are being addressed. As no surface rupture was evident, the concept of a "blind source" needs to be considered ("blind" is defined geologically as denoting faults, usually thrust faults, that do not intersect the surface) [43]. These are a major component of young "neotectonic" movements of the Earth's crust associated with folding. Integral in this is the geological situation (structure and tectonics) of the epicentral area. The Newcastle region contains many complex geological relationships which must now be considered (K. Moelle, pers.comm., 1990, 1991).
In considering the "exact" epicentral location computed from instrumental data, caution must be exercised and the concept of epicentral error recognized. Even with substantial data, such as surface fault scarps, good seismograph station distribution and detailed aftershock sequences, such errors are important. Take, for example, the 1988 Tennant Creek (Central Australia) earthquake sequence. Even with an excellent data set containing all the above, the location error was of the order of a few kilometres over the $30 \mathrm{~km}$ observed (surface) fault scarp [44]. The 1989 Newcastle event did not possess such seismological information. Based on seismic phase arrivals ( $P$ and $S$ waves), the computed epicentral error ellipse was $17 \mathrm{~km}$ by $6 \mathrm{~km}$ [11] (Table 1).

The question of location is clearly indicated by the variations in computational solutions for the main shock, the only aftershock (December 29, 1989) and the subsequent small earthquake to the southwest (February 23, 1990; most probably not an aftershock of the Newcastle earthquake), as shown in Figure 3 and Table 1. The major difficulty, inherent in delineating the source zone, is that of poor station distribution. Additional uncertainties, as manifested in the scatter shown in Figure 3, are due to the use of different data sets, different crustal models and the difficulty in identifying the $S$ (shear) phase (Table 1). The error ellipses from the various locations enclose a total area of about $50 \mathrm{~km}$ by $25 \mathrm{~km}$.

\section{The Size and Source Dimensions:}

The size of an earthquake is usually denoted by the Richter Local Magnitude ML, a seismological standard calculated from the amplitude of $S$ waves recorded on local and regional seismograms with corrections for distance and instrument characteristics. Magnitude is also defined in other forms dependent on other seismic waves monitored by various types of instruments and on the macro-seismic (intensity) data, which are then converted to the common ML scale [45]. Using these methods, an ML 5.6 was determined for the 1989 Newcastle earthquake [11].

In seismological terms, ML 5.6 is only a moderately-sized earthquake, usually not expected to cause the devastating effects witnessed in Newcastle and its environs. This has created a dilemma in reconciling the albeit subjective "size-damage" (the adage that only earthquake with ML $>6.0$ cause "damage") and so further complicating the understanding of the ML scale in physical terms by non-seismologists [46]. The most appropriate physical parameter to describe the source characteristics of an earthquake is the Static Seismic Moment $M_{o}$, the size of the force couple (two opposite forces) that caused the rupture at depth. This is simply given by [47]

$$
\mathrm{M}_{\mathrm{o}}=\mu \mathrm{AD}(\text { dyne-cm) }
$$

where $\mu$ is the rigidity of the rocks at the point of rupture, A is the surface area of the rupture (usually assumed to be circular with an equivalent source radius $r_{s} \mathrm{~km}$ ) and $\mathrm{D}$ is the average displacement of the rocks along the rupture. $M_{o}$ is obtained from teleseismic (worldwide) records of seismic waves by either spectral analysis of the low-frequency components of the seismic waves, or geophysical inversion methods or waveform matching techniques and so can be related directly to the source parameters. A given earthquake can have only one value of $\mathbf{M}_{\mathbf{o}}$. The uniform size estimator now adopted in seismology is the Moment Magnitude $\mathrm{M}$, defined by [48] as

$$
M=2 / 3 \log M_{o}-10.7
$$


TABLE 1: SOURCE LOCATIONS FOR 1989 NEWCASTLE EARTHQUAKE AND AFTERSHOCKS

\begin{tabular}{|c|c|c|c|c|c|c|}
\hline & $\begin{array}{l}\text { Origin } \\
\text { Time } \\
\text { (UTC) }\end{array}$ & $\begin{array}{l}\text { Epicentre } \\
( \pm \text { error })\end{array}$ & $\begin{array}{l}\text { Focal } \\
\text { Depth } \\
( \pm \text { error })\end{array}$ & $\begin{array}{l}\text { Instrumental } \\
\text { Data Sourse }\end{array}$ & $\begin{array}{l}\text { Number of } \\
\text { Stations }\end{array}$ & $\begin{array}{l}\text { Richter } \\
\text { Magnitude } \\
\text { ML }\end{array}$ \\
\hline \multicolumn{7}{|l|}{ MAINSHOCK 27.12 .89} \\
\hline $\mathrm{BMR}$ & $23: 26: 58 \quad$ hrs & $\begin{array}{cc}32.95^{\circ} \mathrm{S} & ( \pm 6 \mathrm{~km}) \\
151.61^{\circ} \mathrm{E} & ( \pm 17 \mathrm{~km})\end{array}$ & $\begin{array}{l}11.5 \pm 0.5 \mathrm{~km}) \\
\text { (constrained) }\end{array}$ & $\begin{array}{l}\text { Australian regional } \\
\text { stations }\end{array}$ & 17 & 5.6 \\
\hline ANU & $23: 26: 56.7 \mathrm{hrs}$ & $\begin{array}{cc}33.01^{\circ} \mathrm{S} & ( \pm 5 \mathrm{~km}) \\
151.78^{\circ} \mathrm{E} & ( \pm 5 \mathrm{~km})\end{array}$ & $15.0( \pm 5 \mathrm{~km})$ & $\begin{array}{l}\text { ANU SE Australia } \\
\text { local network } \\
\text { (no } S \text {-wave data used) }\end{array}$ & 11 & - \\
\hline USGS/PDE & $23: 26: 56.7 \mathrm{hrs}$ & $\begin{array}{r}32.97^{\circ} \mathrm{S} \\
151.62^{\circ} \mathrm{S}\end{array}$ & $\begin{array}{l}10.0 \\
\text { (constrained) }\end{array}$ & Worldwide stations & 132 & 5.4 \\
\hline AFTERSHOCK 29.12.89 & & & . & & & \\
\hline$\overline{\mathrm{BMR}}$ & $09: 08: 09.6 \mathrm{hrs}$ & $\begin{array}{c}32.96^{\circ} \mathrm{S} \\
151.63^{\circ} \mathrm{E} \quad( \pm 3 \mathrm{~km}) \\
( \pm 4 \mathrm{~km})\end{array}$ & $13.6(0.8 \mathrm{~km})$ & $\begin{array}{l}\text { Local portable network } \\
\text { around Newcastle }\end{array}$ & 10 & 2.1 \\
\hline ANU & $09: 08: 00.0 \mathrm{hrs}$ & 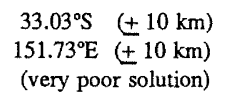 & - & $\begin{array}{l}\text { ANU SE Australia } \\
\text { local network }\end{array}$ & 5 & 2.6 \\
\hline \multicolumn{7}{|l|}{ EVENT OF 23.2 .90} \\
\hline BMR & 12:43:12.4 hrs & $\begin{array}{ll}33.01^{\circ} \mathrm{S} & ( \pm 7 \mathrm{~km}) \\
151.43^{\circ} \mathrm{E} & ( \pm 7 \mathrm{~km})\end{array}$ & $11.3( \pm 10 \mathrm{~km})$ & $\begin{array}{l}\text { Local SE Australia } \\
\text { stations and two } \\
\text { portables in Newcastle }\end{array}$ & 13 & 2.9 \\
\hline ANU & $12: 43: 14.7 \mathrm{hrs}$ & 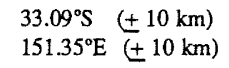 & $20.6(5 \mathrm{~km})$ & $\begin{array}{l}\text { ANU SE Australia } \\
\text { local network }\end{array}$ & 10 & 3.0 \\
\hline
\end{tabular}

BMR - Bureau of Mineral Resources, Canberra : $[11,50]$

ANU - Research School of Earth Sciences, Australian National University, Canberra : J. Weekes and B. Kennett, pers. comm. 1990, 1991

USGS/PDE - US Geological Survey Preliminary Determination of Epicentres

CRUSTAL MODELS: BMR [11], ANU (Modified SE Australian model), USGS (Jeffreys - Bullen global model)

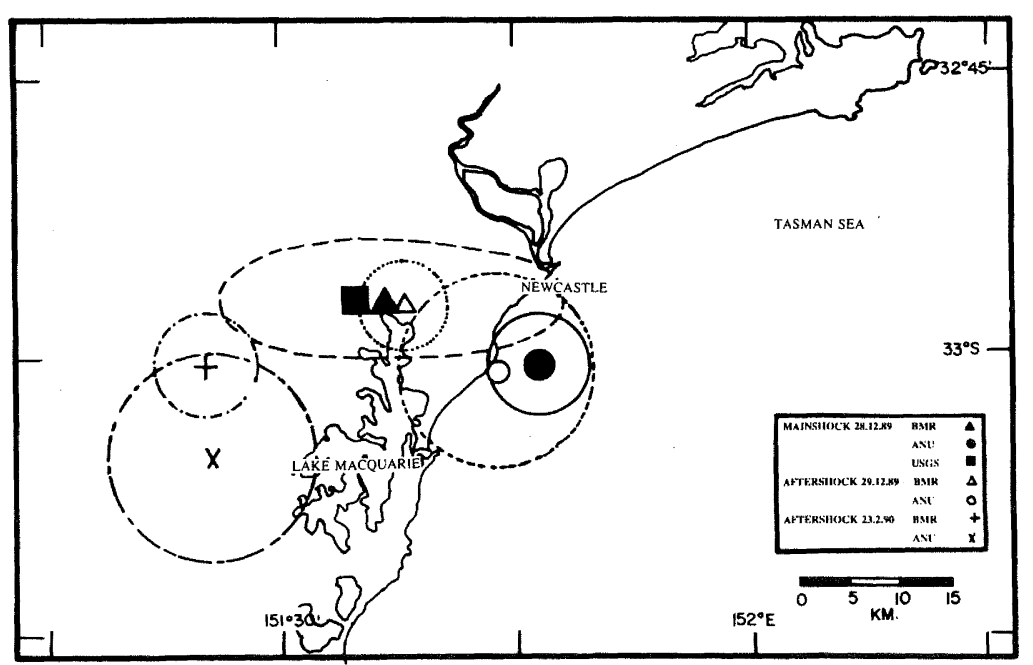

FIGURE 3 ERROR ELLIPSES FOR EPICENTRES OF THE 1989 NEWCASTLE MAINSHOCK AND AFTERSHOCKS (PER TABLE 1) 
For this Newcastle earthquake, such computational results are not yet available. To obtain some estimate of the source parameters, it was assumed that Newcastle behaved as a "typical" intraplate or stable continental earthquake. $\mathbf{M}_{\mathrm{o}}$ was determined using both the available instrumental magnitudes and non-instrumental data (macroseismic information as shown in the isoseismal map of Figure 55) in the empirical formulae derived for stable continental regions [49]:

from instrumental data [11]

$\log M_{o}=23.33-1.28 m_{b}+0.26\left(m_{b}\right)^{2}$

$\log \mathrm{M}_{\mathrm{o}}=22.47-0.40 \mathrm{M}_{\mathrm{s}}+0.14\left(\mathrm{M}_{\mathrm{s}}\right)^{2}$

from non-instrumental data (Figure 55)

$\log M_{o}=47.34-10.81 \log A_{f}+1.17\left(\log A_{f}\right)^{2}$
$\log M_{o}=20.94-0.36 \log A_{v i}+0.14\left(\log A_{v i}\right)^{2}$
$\log M_{o}=26.90-3.10 \log A_{v}+0.52\left(\log A_{v}\right)^{2}$
$\log M_{o}=30.62-4.67 \log A_{i v}+0.65\left(\log A_{i v}\right)^{2}$
$\log M_{o}=38.01-7.83 \log A_{i i i}+0.95\left(\log A_{i i i}\right)^{2}$

where $A_{f}=$ total felt area of the earthquake

$A_{v i}, A_{v}, A_{i v}, A_{i i i}=$ areas within the contours defined by the Modified Mercalli intensities MM VI, V, IV, III, respectively,

with the results given in Table 2 .
The moment magnitude (M) can then be calculated from equation (2) noting that the value estimated from the instrumental data, preferably body wave magnitude $m_{b}$, takes precedence over that estimated from the macroseismic data. The variations in $\mathbf{M}$ (as related to $\mathbf{M}_{\mathrm{o}}$ ) are evident from Table 2. Usually, estimates of $\mathbf{M}$ from the macroseismic data (based on the isoseismal map) agree better with estimates from $m_{b}$ than is the case here. Some of this difference may be due to the much more detailed "felt-report" survey done for this earthquake than is normally the case. It is also possible that $m_{b}$ may truly underestimate the size of the earthquake. Teleseismic surface wave magnitude $M_{8}$ (derived from distant worldwide seismograms) are a more robust indicator of $M_{o}$ than is $m_{b}$, but such an $\mathbf{M}_{\mathbf{s}}$ determination is not as yet available.

To a good approximation, the radiated seismic energy $\left(E_{s}\right)$ is related linearly to $\mathbf{M}_{\mathbf{o}}$ by

$$
\mathrm{E}_{\mathrm{a}}=2 \times 10^{-4} \mathrm{M}_{\mathrm{o}} \text { (ergs), }
$$

and can thus be estimated, as given in Table 2 .

As instrumental analyses to determine source dimensions are not yet available, an initial estimate based on studies of intraplate scaling estimates for central and eastern USA earthquakes, in terms of the Brune stress theory [47], were undertaken (unpublished study by the late Professor O.Nuttli; A. Johnston, pers. comm., 1991). For this, Newcastle is considered as a typical intraplate earthquake with source parameter estimates as given in Table 2. For the range of $\mathrm{M}_{0}=1.0 \times 10^{24}-4.12 \times$ 1024 dyne $\mathrm{cm}$, the stress drop would be $\Delta \sigma=24-99$ bars and the slip (or fault displacement) $D=31-126 \mathrm{~cm}$. By comparison, the standard Brune stress drop would be $\Delta \sigma=68$ - 280 bars. Conservative preliminary estimates of the source characteristics are given in Table 3.

TABLE 2 SEISMIC MOMENT $\left(\mathrm{M}_{\mathrm{o}}\right)$, MOMENT MAGNITUDE (M) AND RADIATED ENERGY (E) FOR 1989 NEWCASTLE EARTHQUAKE

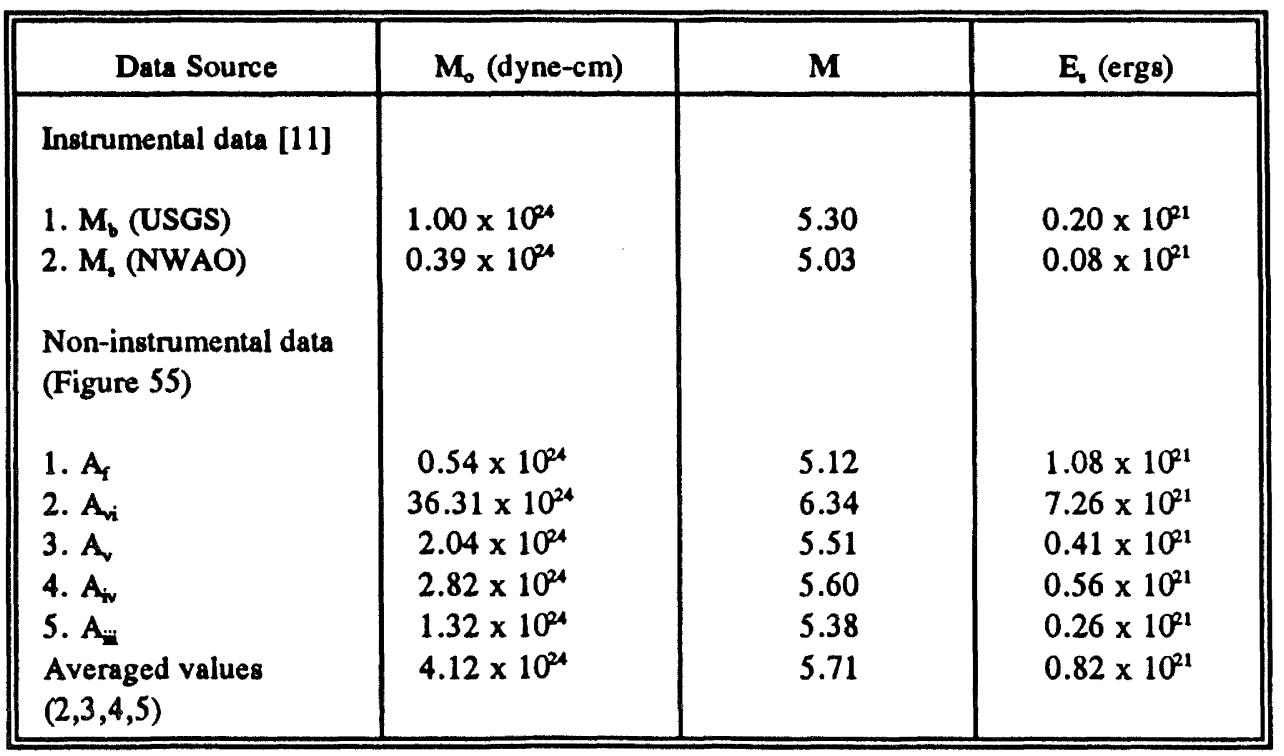

The authors acknowledge Dr Arch Johnston and the staff at the Center for Earthquake Research and Information, (CERI), Memphis State University, for their contributions in preparing this Table. 
TABLE 3 PRELIMINARY ESTIMATES OF SOURCE CHARACTERISTICS FOR THE 1989 NEWCASTLE EARTHQUAKE

\begin{tabular}{||l|l|l||}
\hline Moment Magnitude & M & $5.30( \pm 0.30)$ \\
Seismic Moment & $\mathrm{M}_{\mathrm{o}}$ & $1.0 \times 10^{24}$ dyne. cm \\
Radiated Energy & $\mathrm{E}_{\mathrm{s}}$ & $0.2 \times 10^{21} \mathrm{ergs}$ \\
Corner Frequency & $\mathrm{f}_{\mathrm{c}}$ & $0.60-0.65 \mathrm{~Hz}$ \\
Characteristic Time & $\tau_{\mathrm{s}}$ & $1.55 \mathrm{sec}$ \\
Source Radius & $\mathrm{r}_{\mathrm{s}}$ & $1.86 \mathrm{~km}$ \\
Rupture Velocity & $\mathrm{v}_{\mathrm{s}}$ & $1.20 \mathrm{~km} \mathrm{sec}$ \\
Stress Drop & $\Delta \sigma$ & $24 \mathrm{bars}$ \\
Fault Displacement (Slip) & $\mathrm{D}$ & $310 \mathrm{~mm}$ \\
& & \\
\hline
\end{tabular}

\section{Aftershocks:}

Only one aftershock, of ML 2.1, was recorded and occurred on 29 December 1989 , about 34 hours after the main shock. Using data from the temporary portable network displayed, the epicentre was located at Boolaroo [50], the same location as for the main shock (Table 1; Figure 3). The macroseismic survey of this aftershocks effects yielded 223 reports. The isoseismal map, Figure 4, shows that the strongest effects (MM IV rattling of windows and doors; shaking of houses) were in the suburbs closest to the coast between Newcastle and Redhead. The total felt area was about $150 \mathrm{~km}^{2}$ affecting the region from the eastern shores of Lake Macquarie north to the Hunter River. The effects centred within the Newcastle City area show some similarity to those for the main shock. Few effects were reported from the area surrounding the well constrained BMR epicentre at Boolaroo, this area defining the western limits of perception (Figure 2). Note that the ANU epicentre (Figure 4), determined from totally regional station data is just off the coast near Redhead, the suburb reporting the strongest effects.

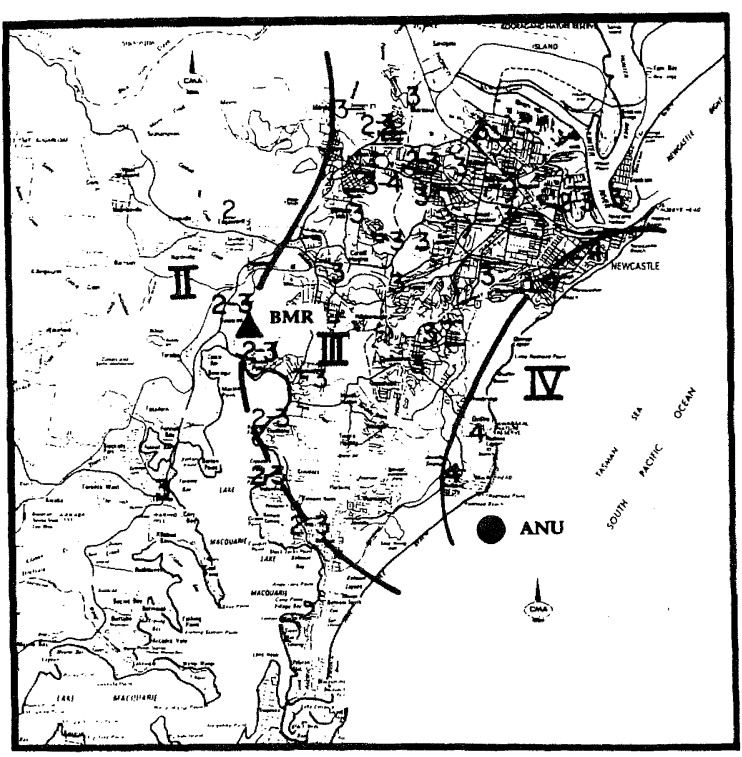

FIGURE 4 ISOSEISMAL MAP (ASSIGNED MM INTENSITY VALUES), OF 1989 NEWCASTLE EARTHQUAKE AFTERSHOCK OF DECEMBER 29, 1989, 0908 HOURS (UTC) ML 2.1
A second earthquake, of ML 2.9, occurred on February 23, 1990 and was located about $25 \mathrm{~km}$ WSW of the mainshock epicentre (Figure 3, Table 1). This is not strictly an "aftershock" of the December 29, 1989 event. Its effects were felt, however, in the devastated area, as shown in the isoseismal map of Figure 5. The macroseismic survey yielded 15 positive felt reports. The felt area covered about $140 \mathrm{~km}^{2}$, being most strongly felt, again with MM IV, in several suburbs around the shores of the northern part of Lake Macquarie. The survey also showed, surprisingly, that in several communities between Lake Macquarie and the epicentre, this earthquake went completely unnoticed.

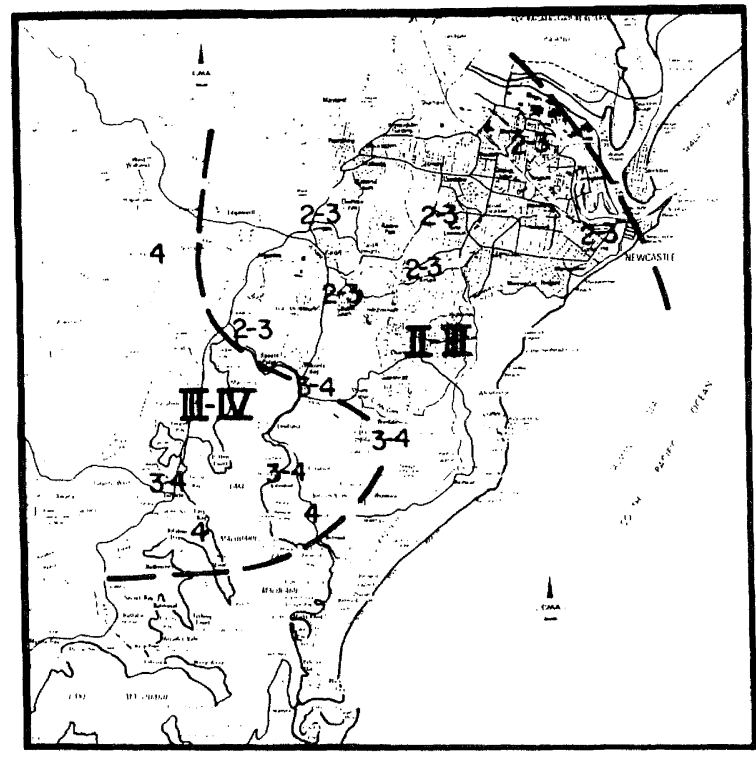

FIGURE 5 ISOSEIMAL MAP (ASSIGNED MM INTENSITY VALUES) OF THE EARTHQUAKE OF FEBRUARY 23, 1990, 1243 HOURS (UTC) ML 2.9 
In the six months following the main shock, many reports of further "tremors" have been received. Most of these have been singular reports from suburbs along the eastern shores of Lake Macquarie. Three of the events, on January 24, 1990 (at $10.06 \mathrm{pm}$ local time), April 18, 1990 (7.50am) and June 20, 1990 (11.08am), were more widely felt in the Belmont - Valentine - Mt Hutton area, on the eastern side of Lake Macquarie. None of these, however, were recorded on the local temporary seismograph and no explanation as to a cause has been forthcoming.

\section{Geological Setting and Source Mechanism:}

The geology of the Newcastle region is complex. A wealth of information exists in structural geology, geomorphology and soil distributions through coal mine data, proprietary company exploration data, specific research projects of the University of Newcastle and marine surveys. Currently a detailed correlation of such data is in progress at the University of Newcastle within its Coal Research Institute (K. Moelle, pers. comm. 1991). A brief summary of the geology is given (based on [51]) with the generalised geology map shown in Figure 6.

The Newcastle region is situated on the Late Permian Tomago and Newcastle Coal Measures deposited in the Lake Macquarie Syncline. These coal measures are comprised of terrestrial sediments and have a thickness of about $1200 \mathrm{~m}$. The Tomago is conformably overlain by the Newcastle, separated by the Waratah sandstone of varying thickness between 10 and $30 \mathrm{~m}$. This complex is a tectonic unit of the Hunter Valley Dome Belt on the northeastern fringe of the Sydney Basin. The region abuts the Hunter - Mooki Thrust System, the boundary with the Newcastle Fold Belt.

The Lake Macquarie Syncline is the dominant structural element. Its northeastern sector has been modified by small scale folding. Two small folds occur in the eastern part of Newcastle City : the Shepherds Hill Anticline with N-S trend, just south of the harbour entrance; the Delta Syncline, with NE-SW trend, covering the mouth of the Hunter River. The whole structure is highly faulted with numerous igneous dykes emplaced within it. The folded Newcastle Coal Measures contain predominantly normal faults striking NW-SE to NNW-SSE and N-S to NNE-SSW with displacements of from 2 to $20 \mathrm{~m}$. Reverse and thrust faults show distinctly different trends, ENE-WSW to E-W and, to a lesser extent, N-S and NNE-SSW.

Swarms of early Tertiary igneous dykes occur throughout the coal measure sequences. They are predominantly parallel to the small scale NW-SE trending normal faults. Dyke swarms parallel to thrust faults, with $\mathrm{N}$ to NNW-S to SSE and WNW-ESE trends have also been mapped. Thicknesses are highly variable in the range from about $100 \mathrm{~mm}$ to $30 \mathrm{~m}$. Shear zones showing occasionally strike-slip movement with WNW-ESE trends have also been mapped.

There has been extensive underground coal mining in the Hunter Valley region for over 100 years. With the exception of those mines in the Newcastle CBD area, such operations continue today. Mining was done by the bord and pillar method and many of the non-operational mines are still intact. Remarkably little mining induced subsidence has been observed. The maintenance of such lateral cohesion is most probably due to the very high horizontal to vertical pressure ratio of about $2: 1$ frequently measured in the district.

The near surface sediments (alluviums) played a vital role in the devastation to the epicentral region. A significant portion of Newcastle City is built on alluvium deposited since the closing of the Pleistocene ice age, which began about 110,000 years ago and continues today. These are Holocene in age and are invariably shown on maps as Quaternary (Figure 6). (It should be noted that the Quaternary is comprised of Pleistocene and Holocene sediments. Throughout this paper these recent

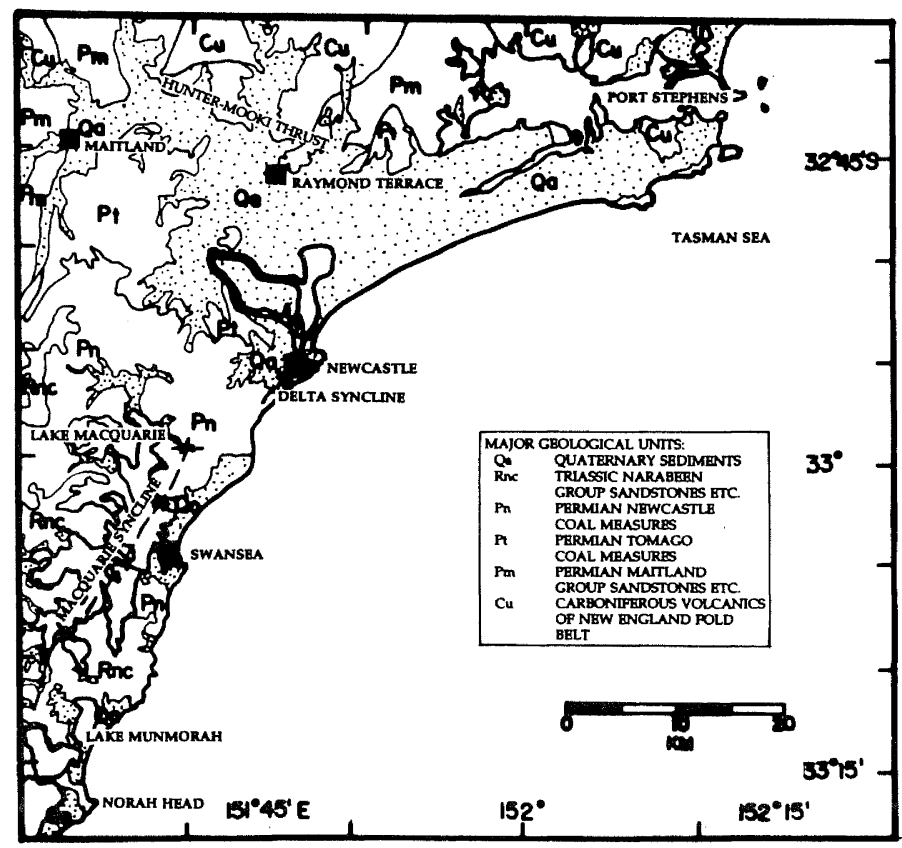

FIGURE 6 GENERALISED GEOLOGY MAP OF THE 
sediments will be referred to as Holocene.) This recent sediment is a combination of well sorted and classified marine sands and poorly sorted fluvial sands, silts and muds. Mixed into this are layers of organic-rich material of a peat-type composition and, in some places, poorly indurated sand. This complex alluvial layer is largely saturated to within a metre of the surface. In some parts, the surface layer is windblown dune sand that has covered an otherwise swampy surface.

Geomorphologically, the entire Newcastle-Lake Macquarie region is an intermix of sediment filled drowned stream valleys and protruding ridges of land rock. In considering damage patterns in far-field locations to the north, west and south of the epicentral region, the dominant geology of interest is again that of Holocene sediments, marine sands in the coastal areas and fluvial sediments inland [52].

The source (or focal) mechanism for the Newcastle earthquake, given by [11] and discussed in [50], suggests that rupture occurred on a thrust fault striking $150^{\circ}$ (approximately NW-SE) with a dip of $75^{\circ}$ to the NE. Because of the uncertainties involved, this solution may not be well constrained. Thus, with some assumptions made in an attempt to correlate the observed damage with an idealised seismic wave radiation pattern based on the suggested mechanism (P.L.Kleeman in Chapter 3 of [9]), any inferences drawn must be considered with some caution.

\section{OBSERVATIONS}

The observations of damage and other felt effects play a vital role in analysing the consequences of the 1989 Newcastle earthquake and, subsequently, translating the results into a programme to mitigate the earthquake hazard in continental Australian and other urban environments. The importance of this macroseismic data cannot be overemphasised, particularly as a minimal amount of instrumental information was available because of poor seismograph station coverage and the total lack of accelerographs.
More than 100,000 observations, comprising earthquake questionnaires (felt reports from the field survey conducted jointly by the Newcastle Police Department and The University of Queensland), newspaper reports, audio-visual material (photographs, radio audio tapes, television videos), insurance claims, local authorities files (Newcastle City Council, Lake Macquarie City Council and surrounding City and Shire Councils), other government agencies reports, engineers reports, underground mines information and many individual reports, are currently being analysed. This data relates to the immediate effects of the earthquake and has been carefully screened not to include the now well-known continuing effects due to the severe rain and associated flooding that occurred in late-January and early-February 1990 and subsequent ground movements over the past two years.

The observations have shown that more than 70,000 buildings in a $20,000 \mathrm{~km}^{2}$ area of the New South Wales coast between Sydney and Kempsey and adjacent inland suffered damage. This damage ranged from the destruction of the Newcastle Worker's Club (within which nine lives were lost) (Figure 7) and devastation at the Kent Hotel and other buildings in Beaumont Street, Hamilton (where three lives were lost) (Figure 8 ), to minor cracking in brick and plaster throughout the area and up to about $250 \mathrm{~km}$ from Newcastle (Figures 9 and 10).

FIGURE 7 DESTRUCTION OF THE NEWCASTLE WORKERS' CLUB, KING STREET, NEWCASTLE CBD WHEREIN NINE PERSONS WERE KILLED: CLASSICAL PANCAKE SHEAR FAILURE EXPOSES NEGATIVE MOMENT REINFORCEMENT OVER COLUMNS AFTER FLOORS COLLAPSED

(29.12.89; J.M.W. RYNN)

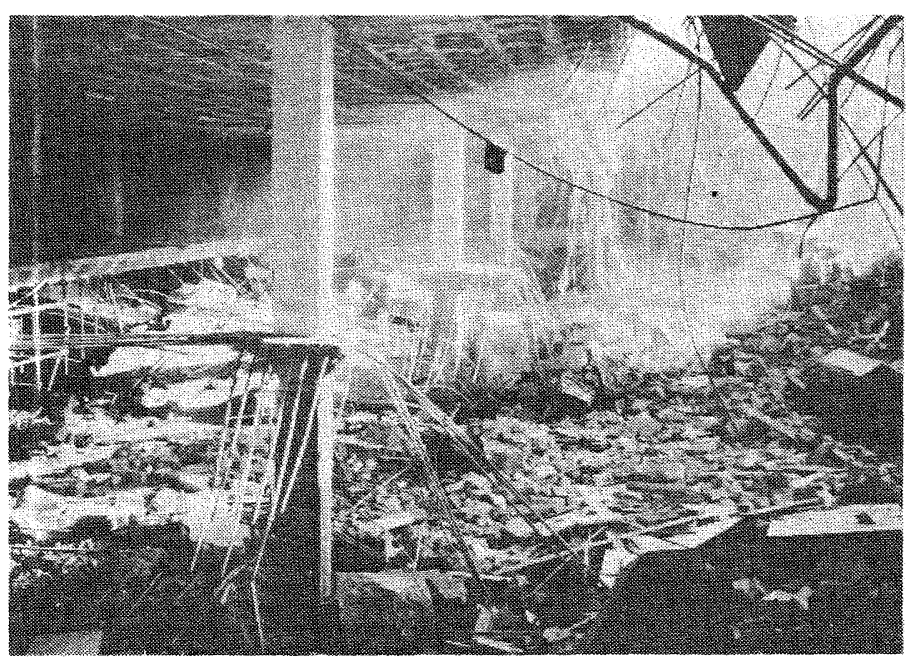



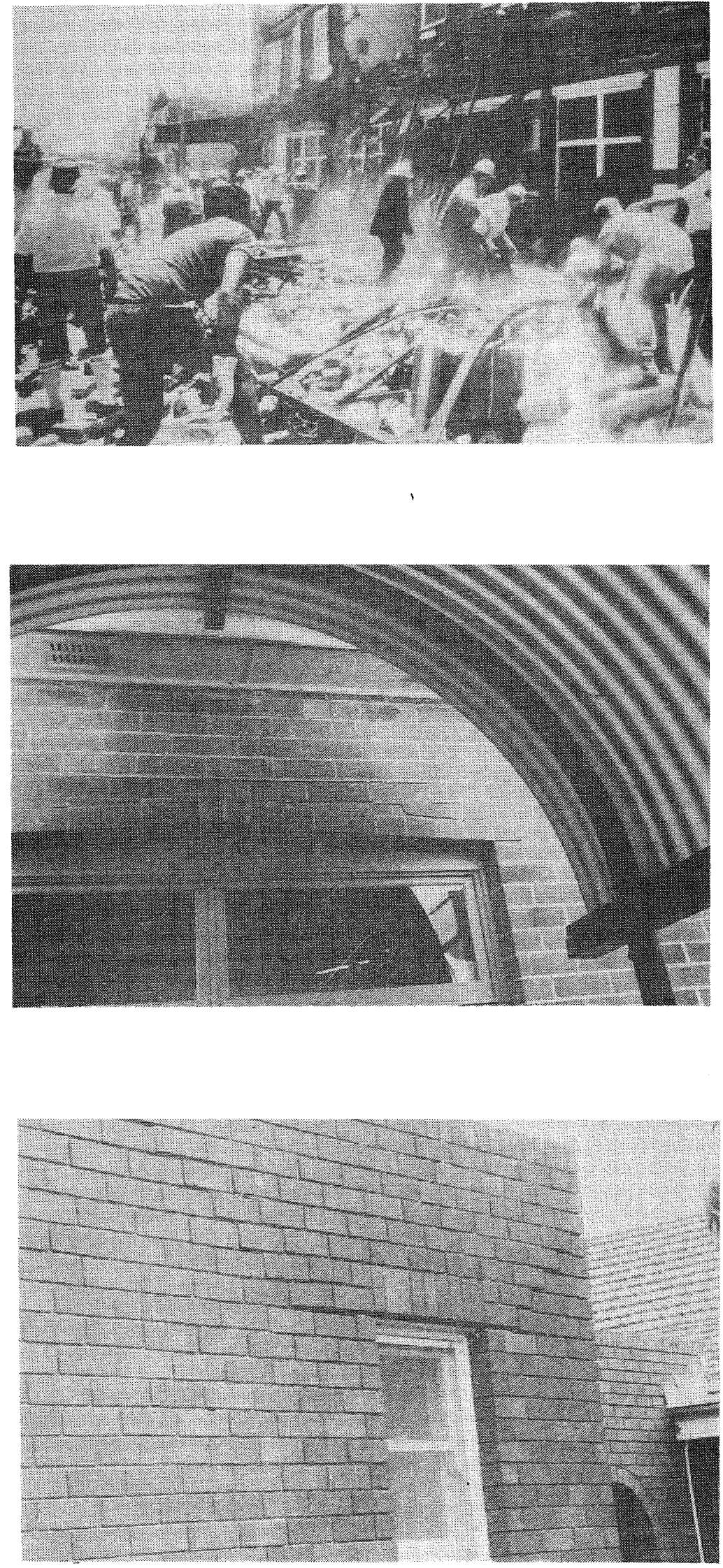

FIGURE 8

DEVASTATION AT THE KENT HOTEL, BEAUMONT STREET, HAMILTON WITHIN MINUTES OF EARTHQUAKE: AFTERMATH OF PARAPET AND AWNING COLLAPSE ONTO FOOTPATH - ALL HANDS TO THE RESCUE:

(28.12.89; "NEWCASTLE HERALD")

\section{FIGURE 9}

ST. LUKE'S PARISH CHURCH HALL, SCONE, $110 \mathrm{~km}$ NW OF NEWCASTLE: TYPICAL DIFFERENTIAL MOVEMENT AT LINTEL OVER WINDOW ABOVE ENTRANCE DOOR SHOWN BY TENSION CRACKING FROM POINT OF DISCONTINUITY (23.1.90; E.BRENNAN)

\section{FIGURE 10}

LIVERPOOL CHILDREN'S HOSPITAL, SYDNEY, $150 \mathrm{~km}$ SW OF NEWCASTLE: TYPICAL MASONRY DIAGONAL SHEAR FAILURE FROM WINDOW LINTEL (22.1.90; E. BRENNAN) 
In the epicentral region, 40,000 properties were damaged $(10,000$ severely) in the Newcastle City Council jurisdiction, several thousand in Lake Macquarie City and about a thousand in the adjoining districts (Shires of Port Stephens, Great Lakes, Dungog and Wyong and Cities of Mailland and Cessnock). Further afield, damage occurred at Gladstone (near Kempsey) $-250 \mathrm{~km}$ to the north of Newcastle, at Cassilis $-200 \mathrm{~km}$ to the northwest, and at Scone $-110 \mathrm{~km}$ to the northwest. Within the greater Sydney area, up to $150 \mathrm{~km}$ to the south-southwest (Figure 1), more than 20,000 reports of building damage are known.

The detailed assessment of dantage is being undertaken through groupings of governmental, commercial and private buildings and consideration of infrastructure and consequential losses. This follows the initial assessments (first few weeks after the earthquake) as reported in [8], supplemented by the macroseismic field surveys and collation of engineering and insurance data.

\section{BUILDING DAMAGE:}

\section{Local Government Authorities}

Most of the buildings owned and/or operated by the Newcastle City Council suffered some degree of damage. Such buildings were not designed to take lateral earthquake loads, with many of them more than 30 years old. Although no major structural damage was reported (G. Bubb in [8]), serious and extensive damage to unreinforced masonry, brick walls and parapets in particular, occurred at The Hamilton Council Chambers (clock tower; Figure 11), Library Building and several buildings in the Civic Block and Newcastle West Art Centre. Of specific note was the damage to the unused City incinerator which suffered so severely that it had to be demolished (Figure 12). Damage occurred to lift shafts and stairwells in three Council carparks and at the Art Gallery. Most buildings sustained some cracking of walls, fallen parapets and other damage to internal fittings. It was observed that the Council's Main Administration Building (of seven storeys plus basement) in the CBD suffered no damage, (Figure 13). The impact on the City of Newcastle in the period following the earthquake has been devastating [53]: more than 40,000 properties damaged, 10,000 severely; about 400 of the City Council's 450 properties damaged; Hamilton business area devastated; severe disruptions to CBD with 50\% damaged; 69,000 insurance claims totalling about \$AUI billion; the damage to City estimated at about $\$ A U 1.5$ billion; considerable consequential losses to Council revenue because of such losses to local business and the public infrastructure.

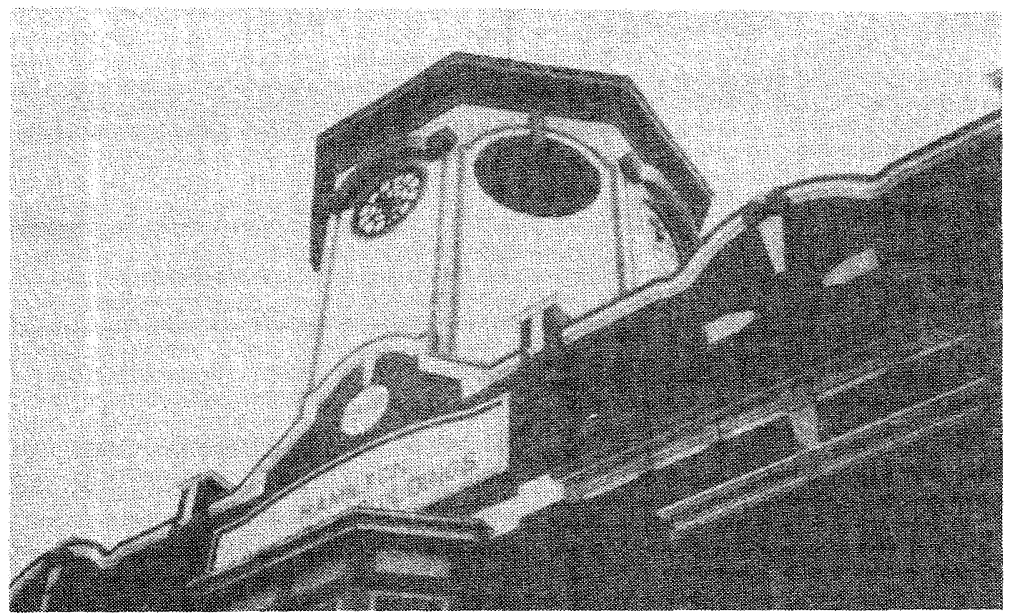

FIGURE 11

HAMILTON COUNCIL CHAMBERS CLOCK TOWER, BEAUMONT STREET, HAMILTON, AFTER RESTORATION. UNREINFORCED MASONRY BRICK PARAPETS AND CLOCK TOWER SO BADLY DAMAGED THEY HAD TO BE DESTROYED.

(24.10.91; H.J.STUART)

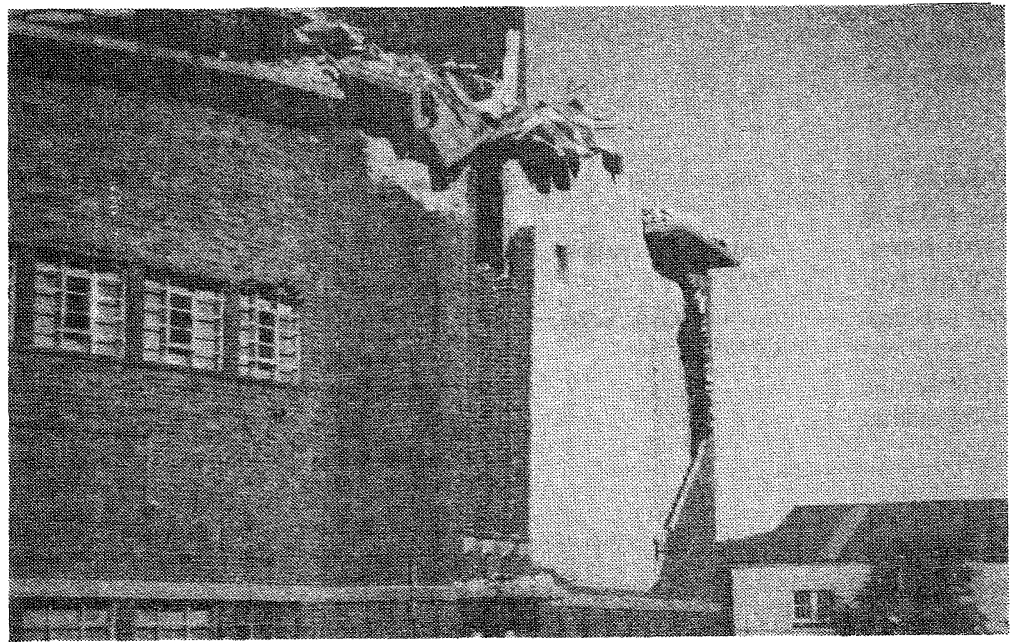

FIGURE 12

NEWCASTLE CITY COUNCIL MUNICIPAL INCINERATOR IN PARRY STREET, NEWCASTLE CBD: OUTER SKIN OF MASONRY BRICK WALL DISCONNECTED FROM INNER SKINS (COLLAPSE THREE STOREYS HIGH, WITH COLLAPSE OF BRICK PARAPET AND ROOF. THIS DAMAGE SUFFICIENT TO WARRANT ITS DEMOLITION.

(30.12.89; J.M.W. RYNN) 


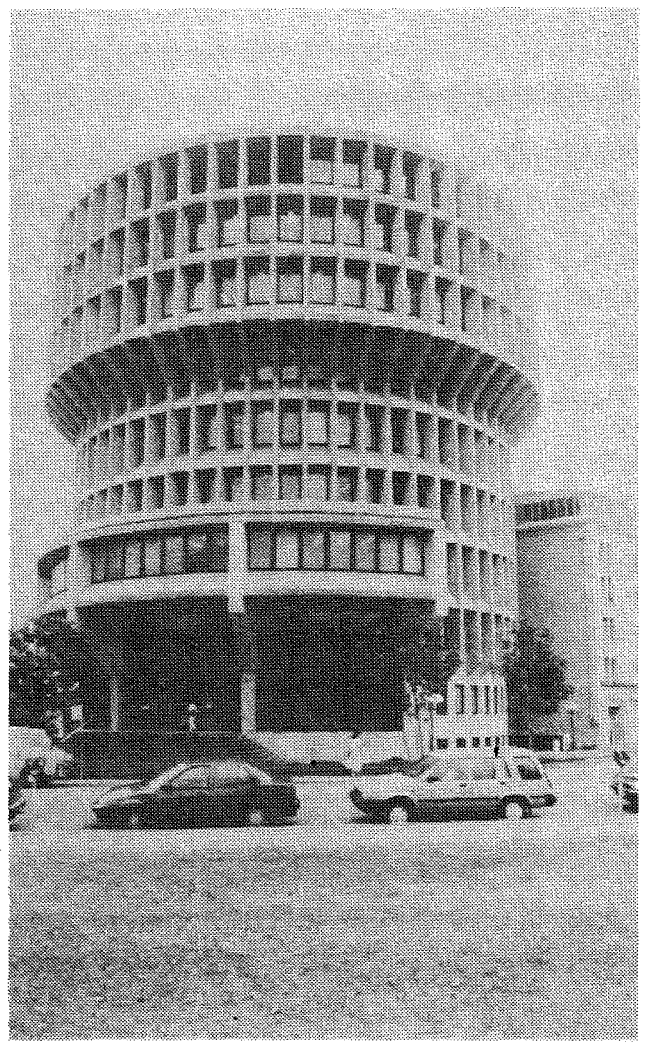

FIGURE 13 NEWCASTLE CITY COUNCIL ADMINISTRATION BUILDING AT CORNER OF KING AND BURWOOD STREETS, NEWCASTLE CBD WHICH DID NOT SUFFER ANY DAMAGE WHATSOEVER. (H.J. STUART)

Buildings within the Lake Macquarie City authority suffered similarly to those in Newcastle City, albeit with much less devastating effects (G.Murphy; pers. comm. 1990, 1991). Extensive damage was caused to the Council Administration Building in Speers Point and to many sporting and amenities buildings, community halls and rented dwellings. The majority of damage in the City was suffered by private residential dwellings, totalling several thousand. It is observed that within this City, a large number of buildings were of timber construction and these fared much better than their unreinforced masonry counterparts. The damage to contents and consequential losses was again very significant.

In the adjoining shires and cities areas, most of the damage was minor although there were several instances of serious wall and ceiling damage to older public buildings and private residences. These areas included Cessnock City, Great Lakes Shire, Port Stephens Shire, Maitland City (the most serious damage occurred within the City precincts particularly along the flood plain of the Hunter River) and Wyong Shire. A report from the Murrurundi Shire, about $80 \mathrm{~km}$ northwest of Newcastle, indicated breakage in a water main.

\section{State Government of New South Wales}

A relatively high number of State Government buildings and facilities were severely damaged in the earthquake. Damage ranged across the spectrum from partial collapse of unreinforced masonry elements (walls, gable roof ends, parapets, chimneys and other relatively unstable sections of buildings) to minor cracking in brick and plaster and displacement of internal fittings, furniture and contents. This description specifically related to educational institutions and critical facilities, including hospitals and emergency services buildings. Damage was such that several buildings were considered for demolition while many others were not able to be occupied in the interest of human safety.

Details of the damage with initial estimates of costs were given as about \$AU(1990)86 million (as at May 1990) covering the epicentral region within about $100 \mathrm{~km}$ of Newcastle [54]. This is most probably an underestimate of the final costs when full restoration is completed. In terms of the State Government budgeting arrangements, the facilities are grouped into Government assets (Inner Budget Sector Authorities; joint funding by Commonwealth and State Governments, etc.), local authorities (reimbursement under National Disaster Relief arrangements, again jointly funded; damage details given in previous section) and Outer Budget Sector Organisations (public utilities, self-funded through insurance, etc.). More than 300 Inner Budget Sector and over 100 Outer Budget Sector sites suffered damage. The costs are quite substantial, with those for the (Inner) Departments of Education and Health totalling about \$AU(1991)50 million and \$AU(1991)20 million respectively. A summary of the damage, to illustrate the effects on public services, is presented in Table 4 , with selected photographs in Figures 14-29.

\section{TABLE 4 SUMMARY OF DAMAGE TO STATE GOVERNMENT OF NEW SOUTH WALES FACILITIES}

Facility Damage

\section{(A) Inner Budget Sector}

Schools - Primary Of 165 in the Hunter Region, only 18 and Secondary were undamaged, 45 sustained structural damage, 102 sustained more minor damage; 3 schools marked for demolition - Wickham Primary, The Junction Primary (each with damage greater than \$AU1 million), Newcastle Special Purposes (damage about \$AU1 million); 6 schools seriously affected (damage about \$AU1 million each) - Broadmeadow High, Kotara High, Merewether High, Lambton High, Newcastle High, Adamstown Infants.

Tertiary Institutes - Newcastle TAFE very seriously and Technical and Further Education (TAFE) extensively damaged with all buildings affected, mostly unreinforced masonry both externally and internally (complete failure, cracking, etc), interior fittings and contents displaced and site of only earthquake related fire, many buildings declared unsafe for public access resulting in partial demolition of the Small Business Centre, Edgeworth David and H.G. Darling buildings, damage estimated at more than \$AU20 million; Hamilton TAFE (3 
Hospitals

Police

Fire Brigades

Ambulance

Court Houses

Corrective
Services
Family and
Community
Services

Corrective

Community Services seriously damaged (more than \$AU1
CBD campuses) extensive major damage, estimated more than \$AU5 million; Charlestown TAFE sustained building damage and substantial contents and consequential damage (more than \$AU1 million); 6 other TAFE colleges in the Hunter district sustained damage.

Lands

More than 27 hospitals and associated health services buildings damaged, with about 150 beds forced out of operation; 3 hospitals each with damage estimates of \$AU10-20 million - Royal Newcastle, John Hunter, Mater Miseri-cordiae; Royal Newcastle Hospital - two wings very seriously damaged to consider demolition, another wing and services block (including part demolition of chimney) sustained major damage, 120 beds out of operation, hospital patients evacuated; Mater Hospital suffered damage to $67 \%$ of its buildings, with Convent building evacuated; John Hunter Hospital was still under construction and sustained serious damage to wall panels, internal walls and electrical and mechanical services; Liverpool Children's Hospital (Sydney) damage to brick walls and internal fixtures, patients evacuated.

20 police stations and residences damaged, all buildings remained in operation.

4 stations in Newcastle City damaged; Historic Cooks Hill (regional headquarters) most seriously damaged with one masonry wall demolished, roof displaced and internal facilities severely disrupted, building evacuated and operations conducted temporarily from a command vehicle outside the build-ing; Less severe damage to Hamilton, Lambton and Tighes Hill Stations.

Widespread damage to more than 20 stations and residences throughout the district; Major damage to Hamilton station (regional headquarters) with part of external masonry wall falling and severe cracking in brick and concrete work.

10 Court Houses sustained damage; Newcastle Court House and Annex were million).

4 prisons sustained major damage.

More than 25 buildings damaged, most of a minor nature; damage to two walls of Worimi Detention Centre. Board

Board

Other
Damage to four properties, the most severe being to the Awabakal Aboriginal Centre (Wickham, Newcastle City) which was unsuitable for occupation and to the Newcastle Showground grandstand and buildings.

Road Transport

Authority

Damage to more than 20 buildings including offices, residences and motor registries.

Other Several other buildings damaged Departments included the Government office block and State Dockyard buildings in Newcastle City.

\section{(B) Outer Budget Sector}

University of Serious damage to unreinforced Newcastle masonry, particularly brick walls, extensive cracking of concrete columns, some structural damage, interior fittings dislodged, contents of bookshelves (particularly in the library) and cupboards displaced and some pipes of the organ in the Main Auditorium dislodged; At least 9 buildings suffered significant damage, some walls considered for demolition; Damage estimated at more than \$AU5 million.

Electricity Power blackout for about 4 hours; Commission Killingworth switching station damaged with failure of porcelain insulators supporting $132 \mathrm{kV}$ circuit breakers; Power transmission lines undamaged.

Railways No damage to railway lines; Buiding damage sustained to 15 railway stations, 4 signal boxes and 7 associated facilities; Overbridge at Tighes Hill sustained some minor damage.

Hunter Water Water supply - minor failures on day of earthquake; widescale damage to pipes and connections became apparent with time; Sewerage - no immediate apparent damage; seepage and subsidence around mains, manholes and pumping stations, observed weeks after earthquake; Damage to more than 25 buildings, in some cases quite severe. No disruption to domestic water and sewerage services.

Maritime

Services

No damage to wharf facilities; Damage to unreinforced masonry in two buildings (office and store) in Newcastle City; Local building facilities at Port Waratah and Kooragang Island disrupted due to power loss; Damage to cable tray in one of the shipsloaders; At Nobby's Light Station (lighthouse) minor damage (cracks in walls, broken window) sustained. in several cases, including the State Bank Hamilton Bus Depot, Grain Corporation silos; Damage to about 1000 Government owned and rented private dwellings. 


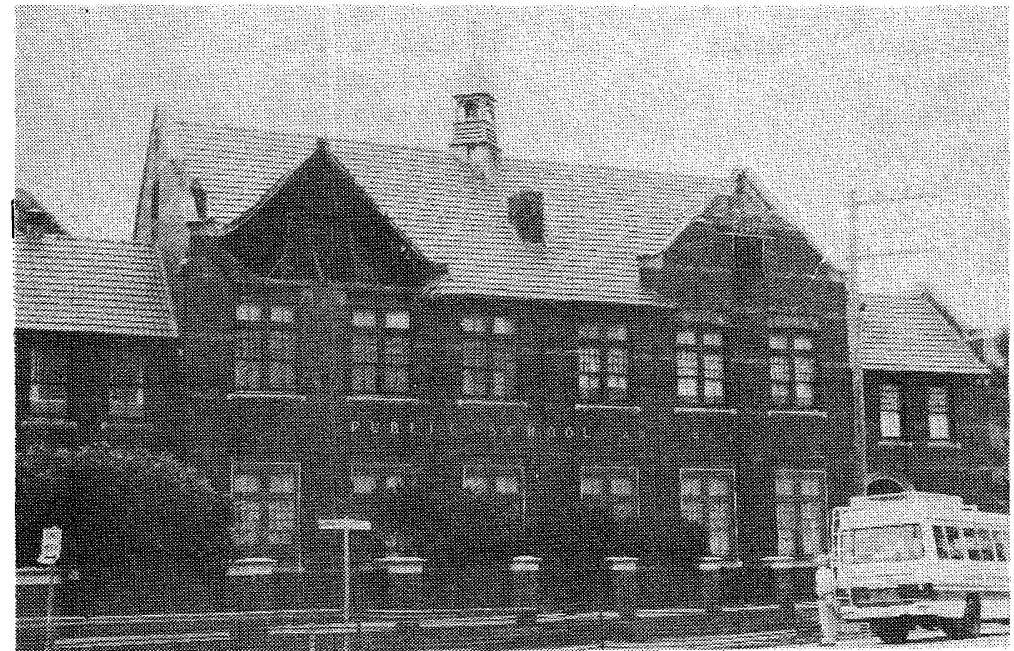

FIGURE 14

WICKHAM PUBLIC SCHOOL, HANNELL STREET, WICKHAM: TYPICAL MASONRY GABLE ROOF ENDS, PARAPETS AND OUTER BRICK SKIN FAILURES. NO LATERAL S UPPORT OF UNREINFORCED MASONRY TO ROOF FRAMING. TYPICAL GABLE DETAIL

(5.1.90: J.M. FENWICK)

FIGURE 15

THE OLD JUNCTION SCHOOL (NOW TAFE COLLEGE), GLEBE ROAD, THE JUNCTION: SHOWS TYPICAL SCHOOL CONSTRUCTION. FAILURE OF UNREINFORCED CAVITY MASONRY GABLE ROOF ENDS, LATERALLY UNSUPPORTED TO ROOF FRAMING. FAILURE IN ROOF CHIMNEY AND BRICK WALLS. MASONRY DEBRIS IN SCHOOL YARD AND DAMAGE TO ADJOINING BUILDING.

(4.1.90; E.BRENNAN)
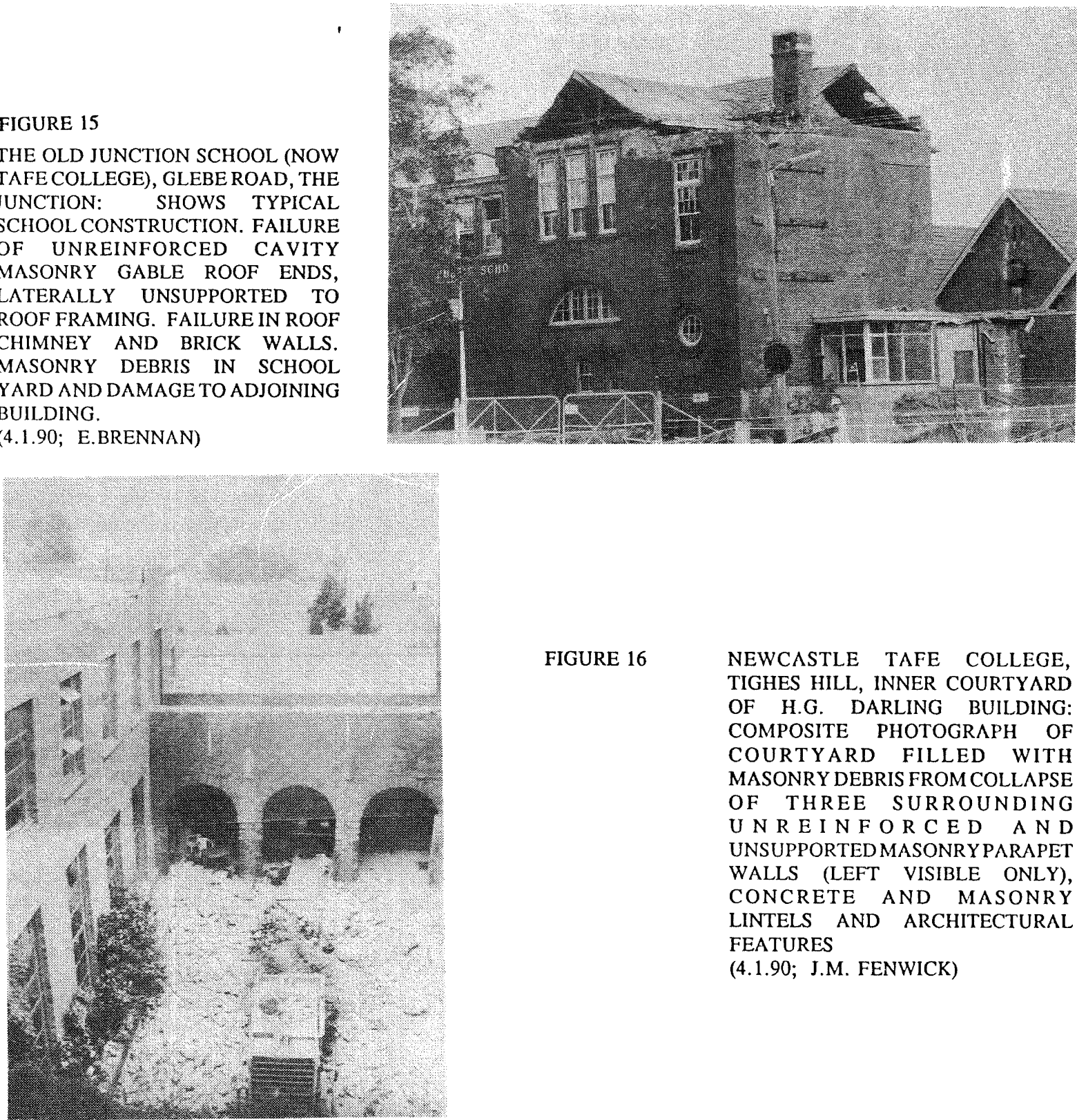

FIGURE 16

NEWCASTLE TAFE COLLEGE, TIGHES HILL, INNER COURTYARD OF H.G. DARLING BUILDING: COMPOSITE PHOTOGRAPH OF COURTYARD FILLED WITH MASONRY DEBRIS FROM COLLAPSE OF THREE SURROUNDING U N R E I N F OR C E D A N D UNSUPPORTEDMASONRY PARAPET WALLS (LEFT VISIBLE ONLY), CONCRETE AND MASONRY LINTELS AND ARCHITECTURAL FEATURES

(4.1.90; J.M. FENWICK) 
FIGURE 17

NEWCASTLE TAFE COLLEGE, TIGHES HILL, CLEGG BUILDING FITTING AND MACHINING SECTION: COLLAPSE OF UNREINFORCED MASONRY (DOUBLE SKIN) GABLE ENDS OF INDUSTRIAL BUILDING DUE TO LACK OF LATERAL SUPPORT $\triangle N D / O R$ BRACING BACK TO FRAME/ROOF TRUSSES. NOTE DEMOLISHED $2 \mathrm{~m}$ HIGH STEEL WIRE TENCE.

(29.12.89; J.M.W. RYNN)
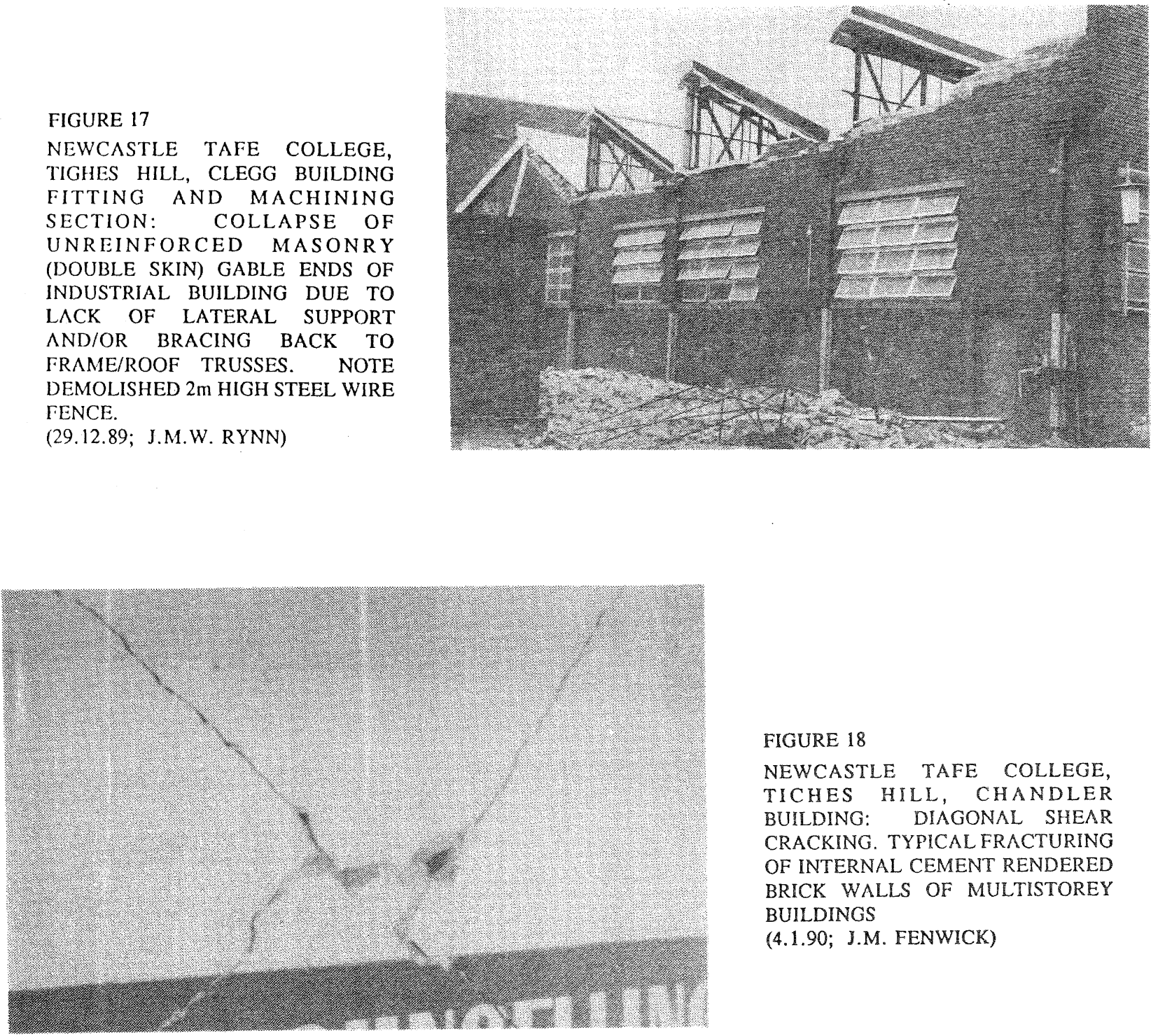

FIGURE 18

NEWCASTLE TAFE COLLEGE, TICHES HILL, CHANDLER BUILDING: DIAGONAL SHEAR CRACKING, TYPICAL FRACTURING OF INTERNAL CEMENT RENDERED BRICK WALLS OF MULTISTOREY BUILDINGS

(4.1.90; J.M. FENWICK)

FIGURE 19

NEWCASTLE TAFE COLLEGE, TIGHES HILL, SMALL BUSINESS CENTRE: COLLAPSED SUSPENDED CEILING AND DAMAGE TO FURNITURE AND FITTINGS (4.1.90; J.M. FENWICK)

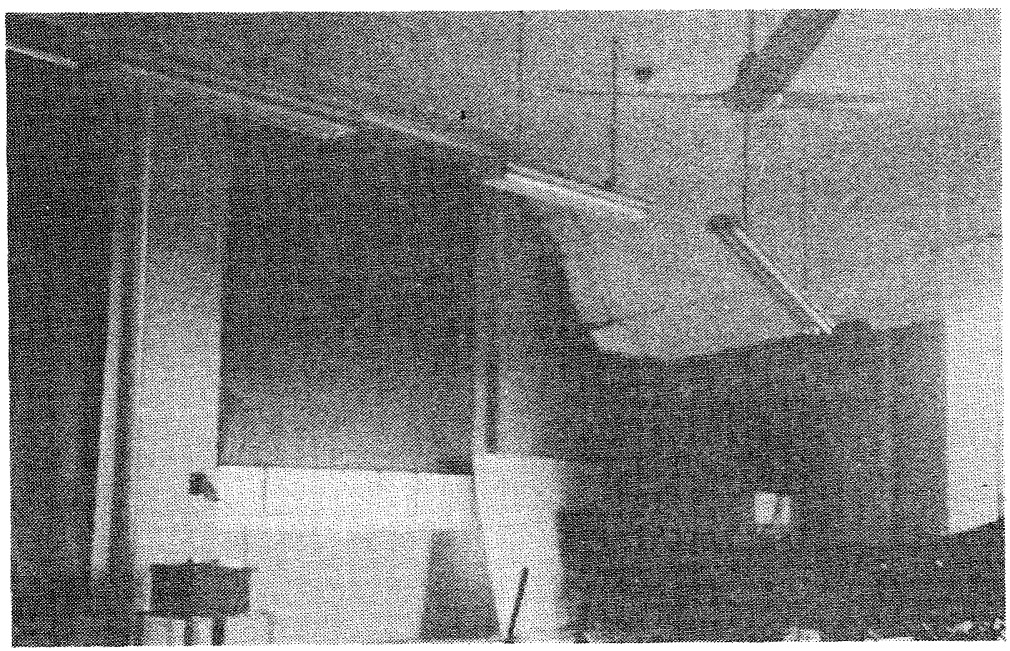




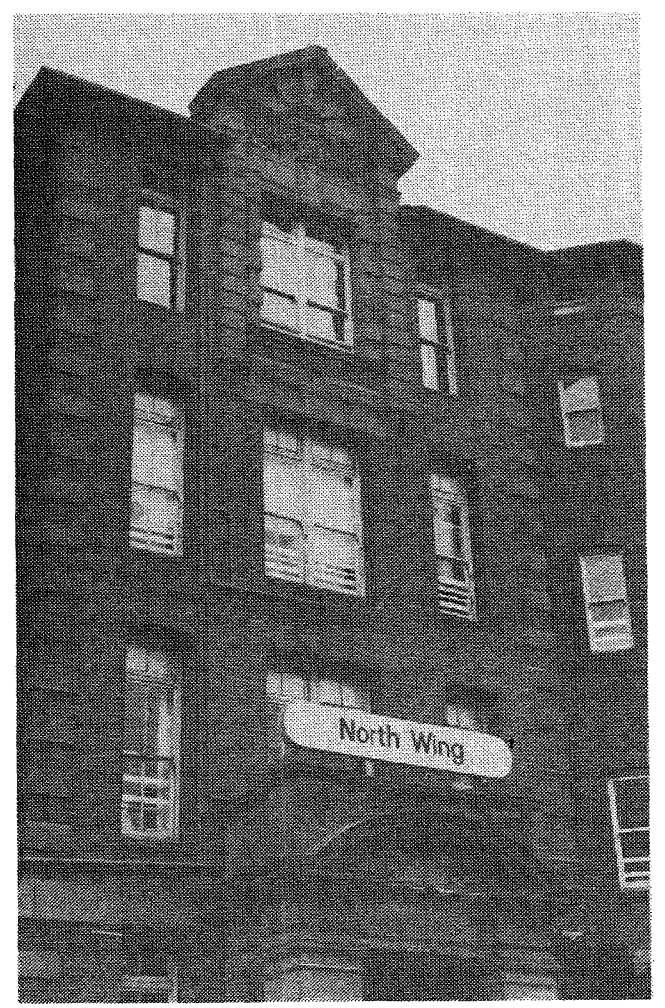

FIGURE 20

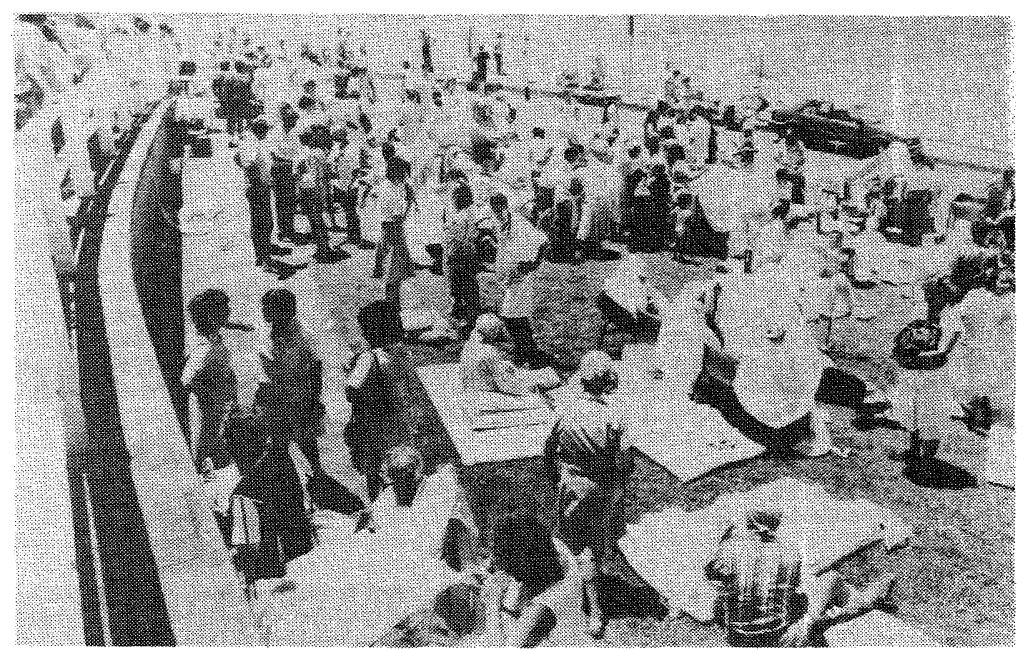

AL NEWCASTLE HOSPITAL, NORTH WING, NEWCASTLE EAST: EXTENSIVE DAMAGE BOTH EXTERNALLY AND INTERNALLY TO MASONRY WALLS, CEILINGS, PARAPETS AND ARCHITECTURAL FEATURES (SIMILAR DAMAGE TO ADJOINING YORK WING; BOTH ORIGINAL WINGS OF HOSPITAL). DAMAGE SEVERE ENOUGH TO CONSIDER DEMOLITION OF BOTH WINGS.

(4.1.90; J.M.FENWICK)

FIGURE 21

ROYAL NEWCASTLE HOSPITAL, NEWCASTLE EAST: EVACUATION OF ALL PATIENTS ONTO BEACH ESPLANADE AND PARK BECAUSE OF PUBLIC DANGER IN DAMAGED BUILDINGS

(28.12.89; NEWCASTLE "HERALD")

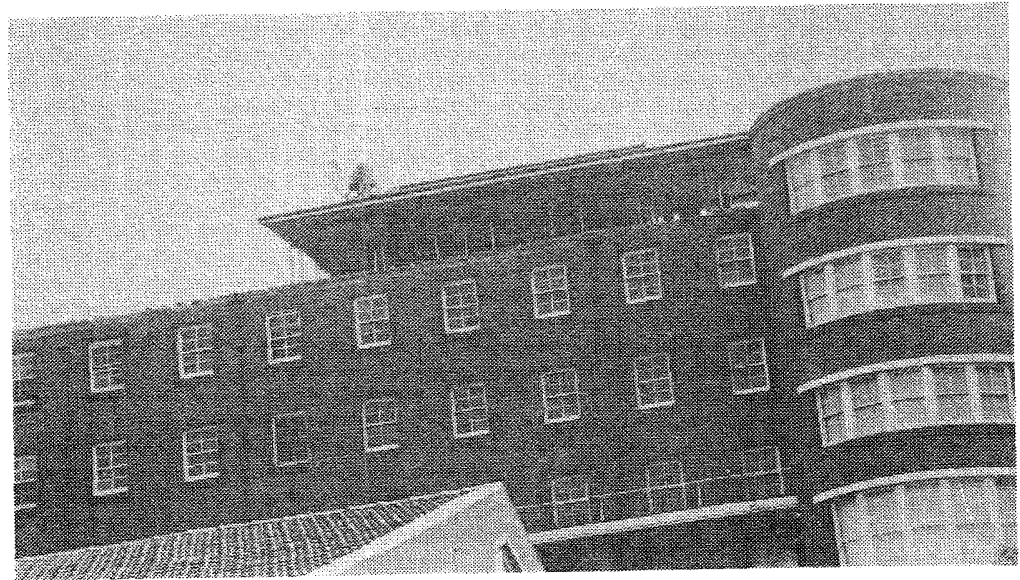

FIGURE 22

MATER MISERICORDIAE HOSPITAL, EDITH STREET, WARATAH: COLLAPSE OF UNREINFORCED MASONRY PARAPET ENCLOSING COVERED WALKWAY AT ROOF LEVEL

(19.1.90; E. BRENNAN) 


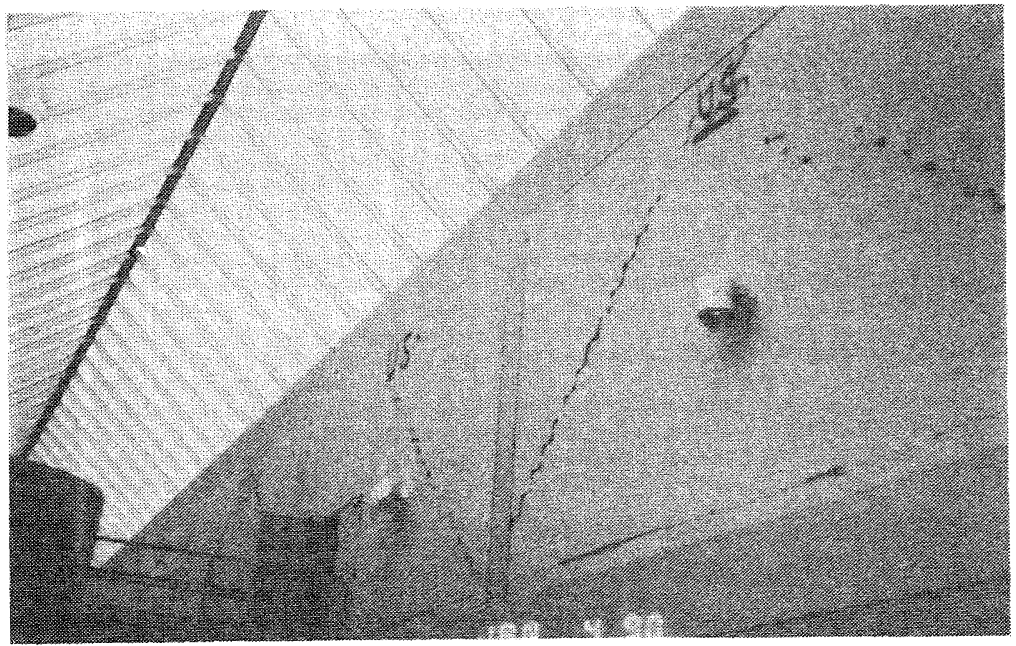

FIGURE 23

THE JOHN HUNTER HOSPITAL, LOOKOUT ROAD, LAMBTON HEIGHTS, SERVICES BLOCK: TYPICAL DIAGONAL SHEAR CRACKING IN UNREINFORCED MASONRY INFILL PANELS (BRICK WITH CEMENT RENDER)

(4.1.90; C.R.FEATERSTONE)

FIGURE 24

THE JOHN HUNTER HOSPITAL, LOOKOUT ROAD, LAMBTON HEIGHTS, SERVICES BLOCK: DAMAGE OCCURRED TO ELECTRICAL AND MECHANICAL SERVICES WITH EXAMPLE HERE OF ANTI-VIBRATION SPRINGS FROM BASE OF AIR CONDITIONING UNIT "POPPED OUT" FOR LACK OF HOLDING DOWN BOLTS

(29.12.89; J.M.W. RYNN)
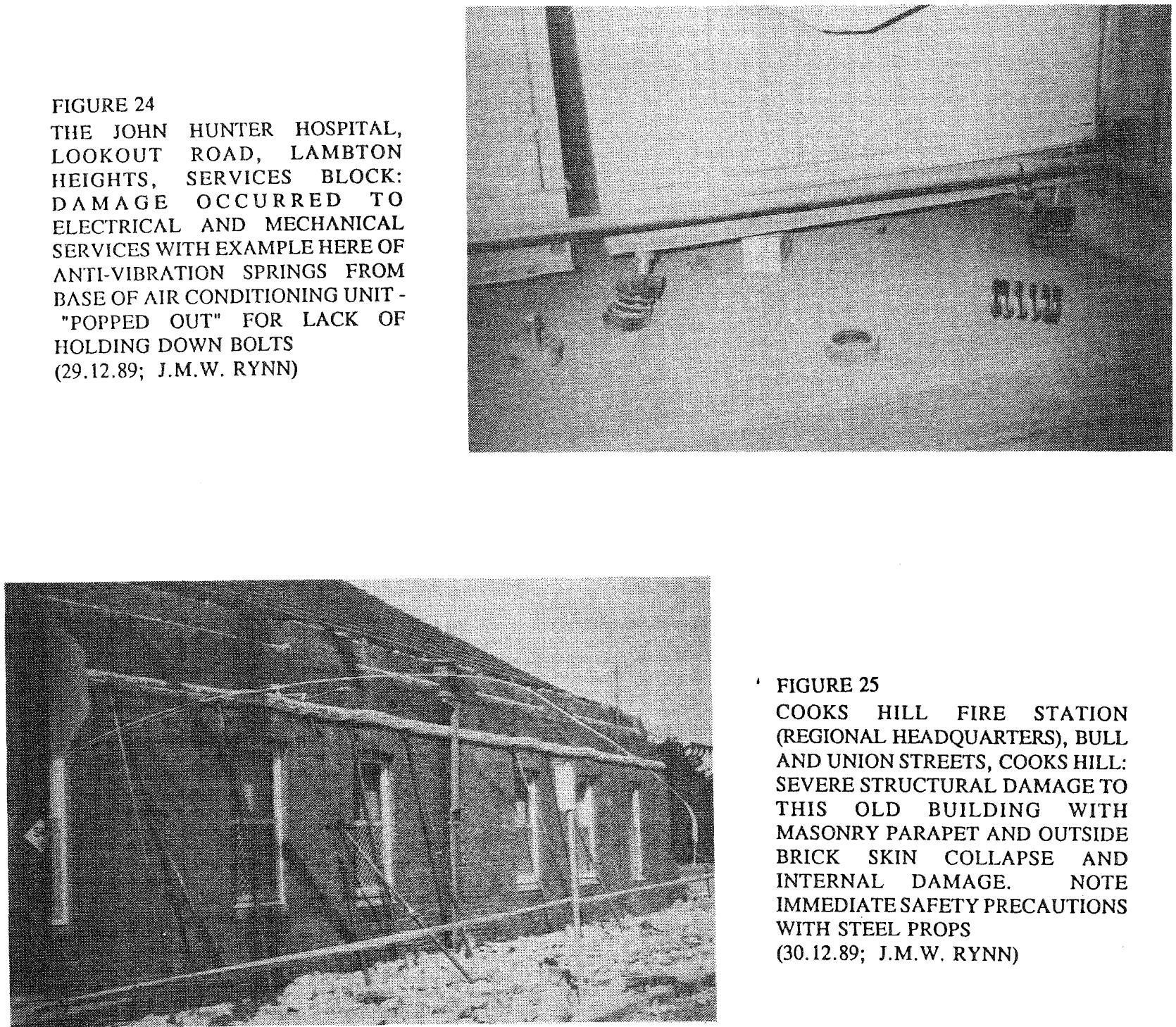

- FIGURE 25

COOKS HILL FIRE STATION (REGIONAL HEADQUARTERS), BULL AND UNION STREETS, COOKS HILL: SEVERE STRUCTURAL DAMAGE TO THIS OLD BUILDING WITH MASONRY PARAPET AND OUTSIDE BRICK SKIN COLLAPSE AND INTERNAL DAMAGE. NOTE IMMEDIATE SAFETY PRECAUTIONS WITH STEEL PROPS (30.12.89; J.M.W. RYNN) 
FIGURE 26

HAMILTON AMBULANCE STATION (REGIONAL HEADQUARTERS), DENISON STREET AND PARKWAY AVENUE, HAMILTON: MASONRY FAILURE OF BOTH SKINS DUE TO LACK OF LATERAL SUPPORT

WALLS. BUILDING ALSO SUFFERED OTHER SEVERE MASONRY DAMAGE

(29.12.89; J.M.W. RYNN)

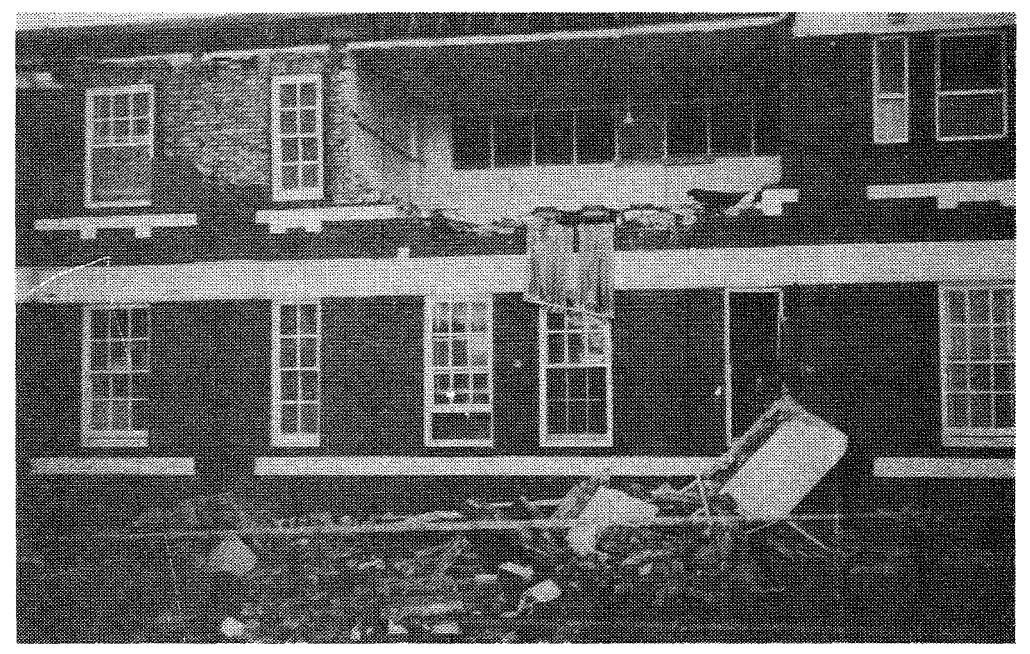

FIGURE 27

N E W C A S T L E P O L I C E HEADQUARTERS, CHURCH AND WATTS STREETS, NEWCASTLE EAST: INTERNAL DAMAGE OF CEILING AND FLUORESCENT LIGHT FITTINGS COLLAPSE SHOWING POOR FIXING DETAIL

(29.12.89; J.M.W. RYNN)

FIGURE 28

UNIVERSITY OF NEWCASTLE: LATERALLY UNSUPPORTED BRICK WALLS

(JULY 1990; H.J. LODHIA)

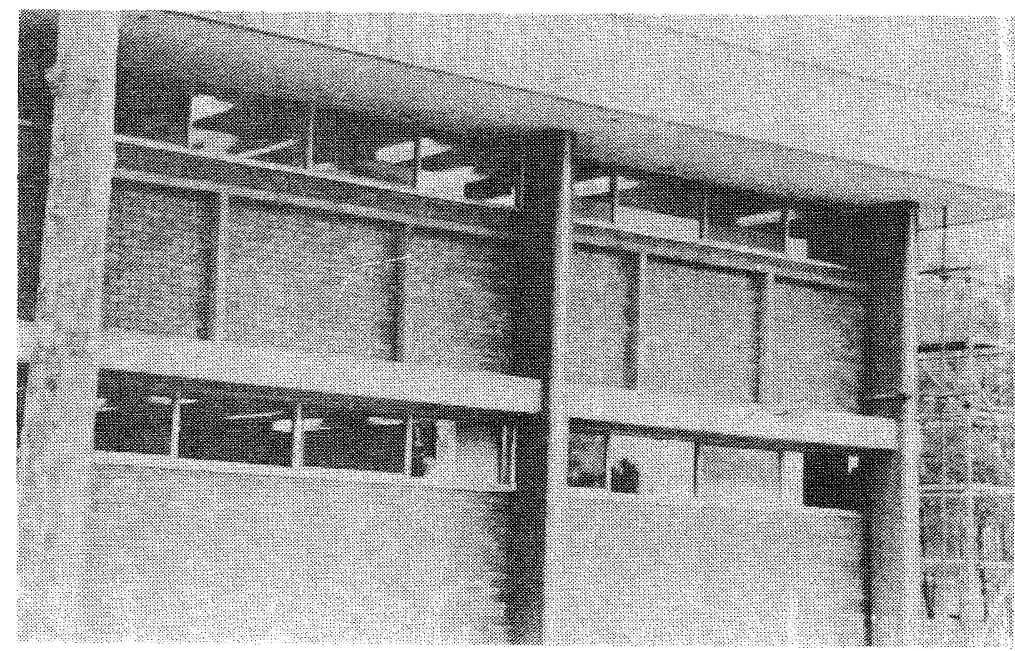




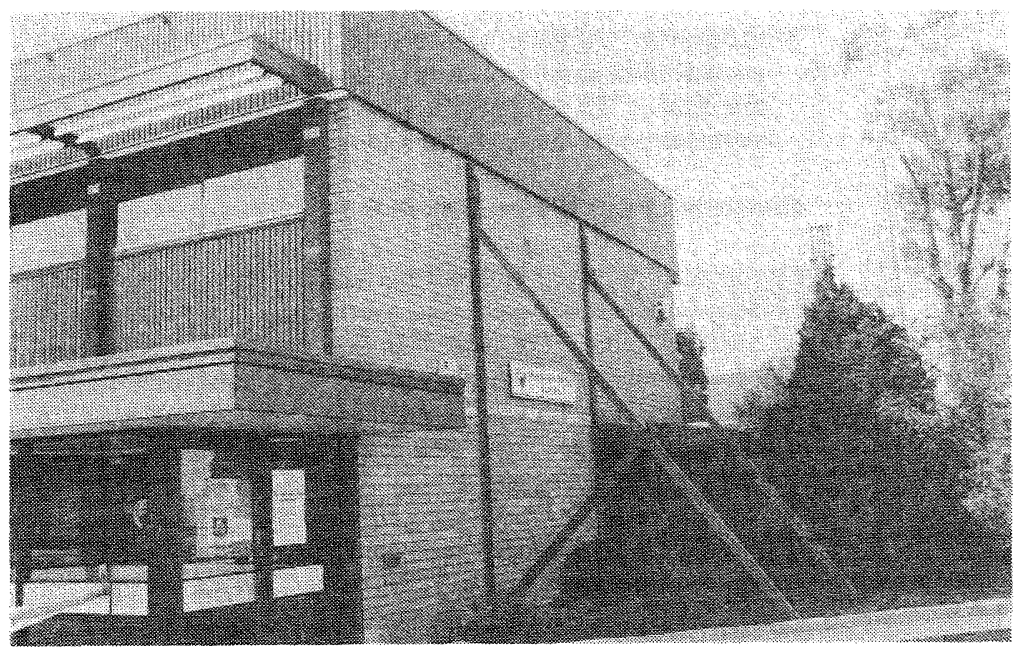

FIGURE 29

ROAD TRAFFIC AUTHORITY BUILDING, PACIFIC HIGHWAY, CHARLESTOWN: SHORING OF UNREINFORCED CAVITY MASONRY FEATURE END WALL WHICH WAS NOT TIED LATERALLY TO AND BECAME SEPARATED FROM SIDE WALLS (20.1.90;E.BRENNAN)

FIGURE 30

TELECOM TELEPHONE EXCHANGE, DENISON AND LAWSON STREETS, HAMILTON: REPAIRED DAMAGE TO UNREINFORCED MASONRY LOADBEARING WALLS OF BRICKWORK SEPARATION AT DISCONTINUITIES IN UPPER PARTS OF OLDER SECTION AT FRONT (21.3.92; D.J. WILLIAMS)

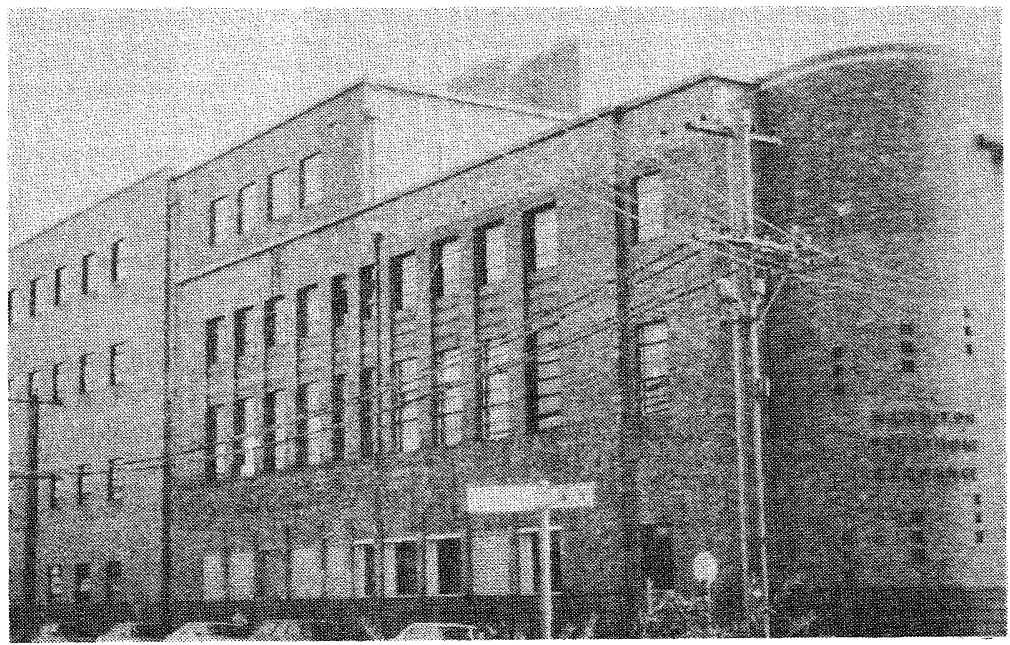

Commonwealth Government

Significant damage was sustained by several Commonwealth Government facilities. These included:

Telecom - Serious disruption to telephone services occurred because of major damage to several telephone exchange buildings in the epicentral region. The worst affected was the exchange at Hamilton (Figure 30). The situation was further exacerbated by the loss of power in the region.
Norah Head Lighthouse - This lighthouse (Figure 31), situated $45 \mathrm{~km}$ SSW of Newcastle near Toukley, is a vital facility for shipping on the busy route between Sydney and Newcastle and the overseas shipping lanes along the east coast of Australia. It is founded on a solid sandstone coastal headland (Figure 6). Built in 1903 of precast concrete masonry blocks, the optical apparatus consists of a lens of $700 \mathrm{~mm}$ focal radius floating in a bath of mercury. This bath experienced a serious mercury spill $(60 \mathrm{~kg})$ because of the horizontal force applied, the liquid percolating down through the tower. The dangers created both to the lighthouse operation and to the staff could have serious consequences. Other damage recorded included a crack in the cast iron pedestal leg of the lens support, several cracks through mortar joints of the lighthouse building (Figure 32), and cracks in several of the station's outer buildings, most severely in the workshop (Lighthouse Keeper P. Bailey and Captain J. Nicholson, pers. comm., 1990, 1991). 


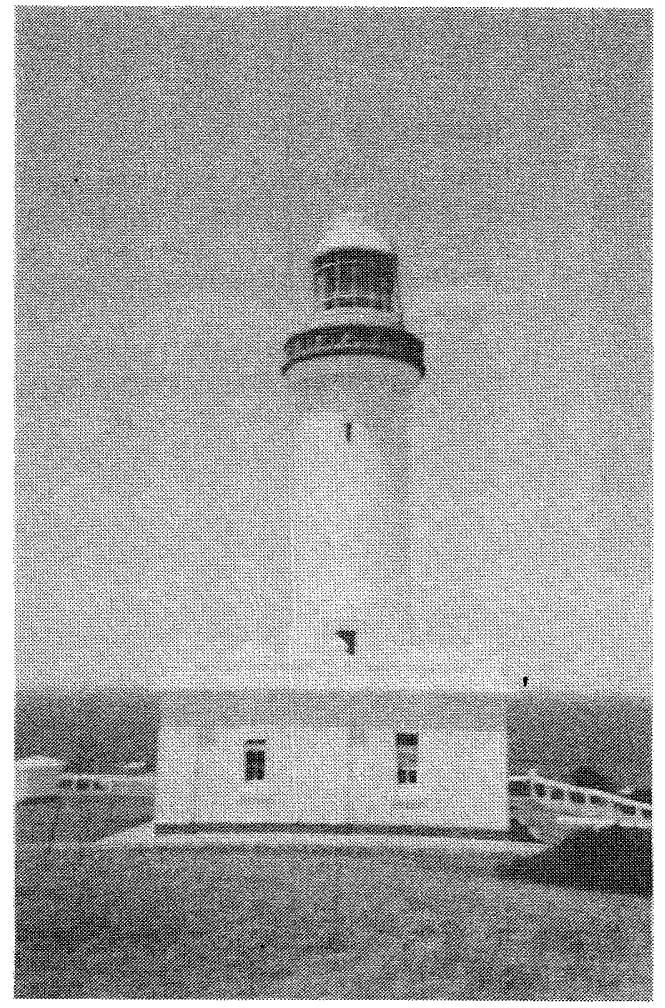

FIGURE 31 NORAH HEAD LIGHTHOUSE, $45 \mathrm{~km} \mathrm{SSW} \mathrm{OF}$ NEWCASTLE

(20.1.90; M.W. RYNN)
Williamstown Airport and RAAF Base - There were unconfirmed reports of damage to some of the buildings on the base. The Airport's Domestic Passenger Terminal sustained some minor damage to internal fittings.

\section{Commercial and Industrial Buildings}

Commercial buildings suffered the most damage, to the extent of many hundreds being affected, particularly those with ages of 30 years or more. The most significant damage was concentrated within the Newcastle City precincts, (around the CBD and Hamilton) and Maitland areas, with isolated instances in surrounding suburbs. The buildings in Lake Macquarie City area suffered to a lesser extent.

The majority of building damage was related to failure of unreinforced masonry [12] manifested in structural collapses of roofs, walls and floors, parapet failure, sheared corners, transverse panel, racking and torsional failures and consequential failures of internal fixtures and fittings. Specific note is made in reference to apartment buildings of the "soft-storey" design (such as the "six-pack" two storey unreinforced masonry brick buildings with accommodation on top floors and open garage space below), hotels, schools, shopping centres and private nursing homes.

Several instances of consequential damage wherein a building, undamaged by the initial shock, suffered serious consequences due to material falling on to it from the adjacent building. Such damage was sustained to the roof, ceilings, upper floors and internal fittings.

The built environment of Newcastle, specifically, includes about 200 buildings and other structures identified by some community members as having historic significance, that is, of heritage value. This situation has caused some major concerns, particularly in relation to several of these "heritage" buildings cited for demolition. A number of these buildings were demolished within the first few days following the earthquake because of substantial risk to public safety (for example: George Hotel and Carrington Chambers in the Newcastle CBD). This heritage issue should be a consideration of all urban environments in Australia (both large cities and small towns) in regard to the potential of future earthquake damage to these buildings (M.Walker in [8]).

A selection of photographs indicating the extent of building damage is given in Figures 33-40.

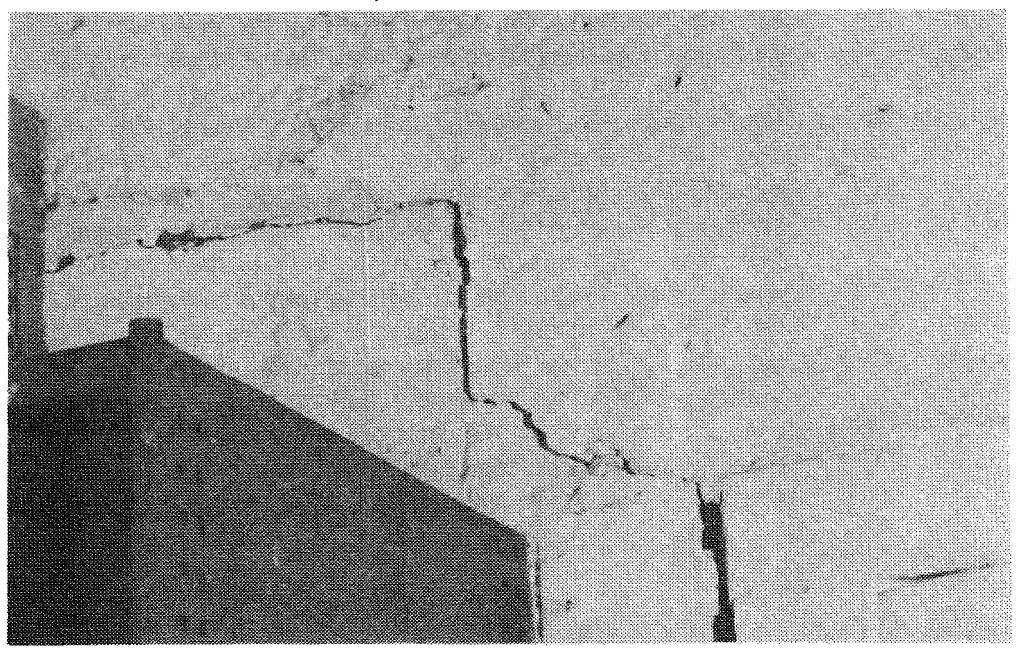

FIGURE 32

NORAH HEAD LIGHTHOUSE, OPERATIONS ROOM: MASONRY SHEAR FAILURE IN CONCRETE BLOCK WALLS WITH CRACKING AROUND CONCRETE MAIN FRAME

(20.1.90; E. BRENNAN) 


\section{FIGURE 33}

HAMILTON RSL CLUB, TUDOR AND CHAUCER STREETS, HAMILTON: SEVERE BUCKLING OF CHAUCER ST. (WESTERN) WALL - OUTSIDE BRICK SKIN FAILURE DUE TO LACK OF LATERAL SUPPORT. WALL STILL CONNECTED TO LOAD BEARING INSIDE SKIN BY BRICK TIES (5.1.90; C.R. FEATHERSTONE)

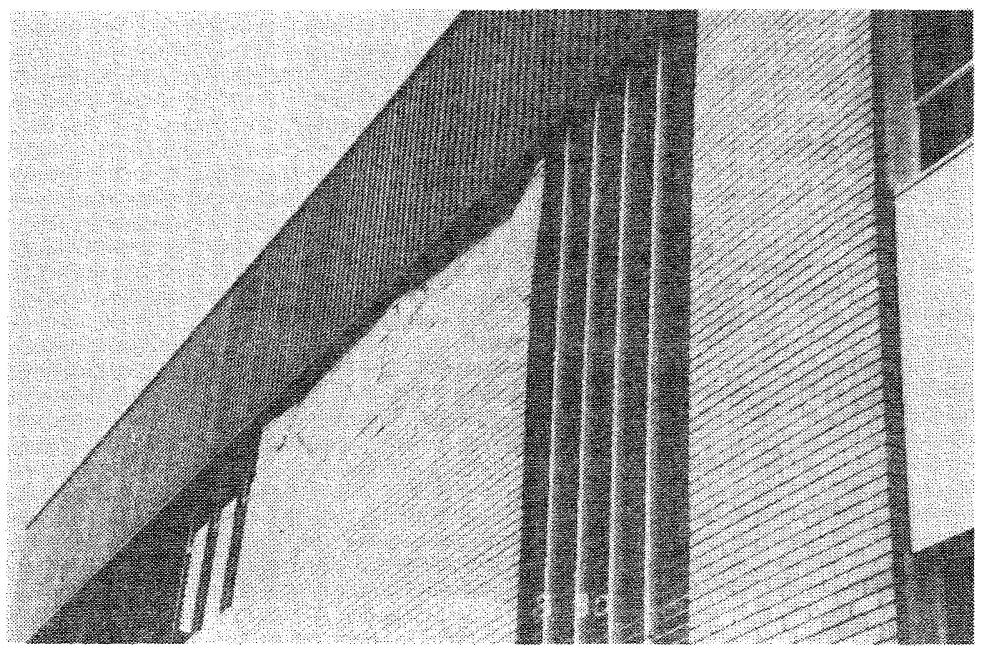

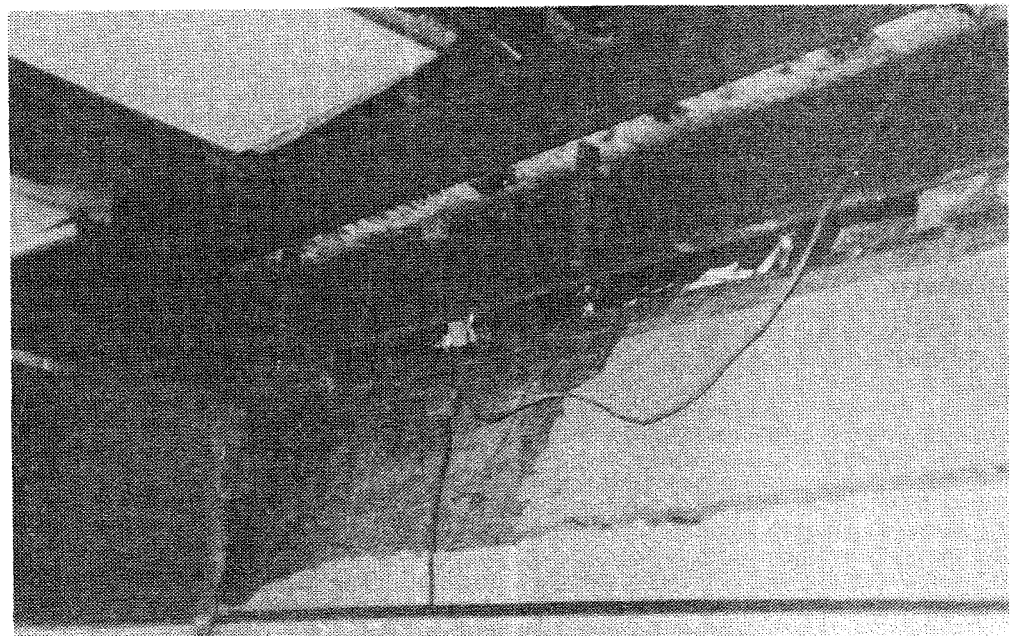

FIGURE 34

HAMILTON RSL CLUB, TUDOR AND CHAUCER STREETS, HAMILTON: DAMAGE TO INTERNAL UNREINFORCED BRICK WALLS AND TO CEILING - LACK OF CONNECTION OF BRICKWORK TO MAIN BRICKWORK PIERS AND TO ROOF PURLINS

(5.1.90; C.R. FEATHERSTONE)

FIGURE 35

HAMILTON RSL CLUB, TUDOR AND CHAUCER STREETS, HAMILTON: FAILURE OF INTERNAL BRICK WALL TYPICAL DIAGONAL SHEAR CRACKING IN MASONRY WALLS. NOTE LACK OF CONNECTION OF INFILL BRICKWORK TO CONCRETE FRAME

(5.1.90; C.R. FEATHERSTONE)

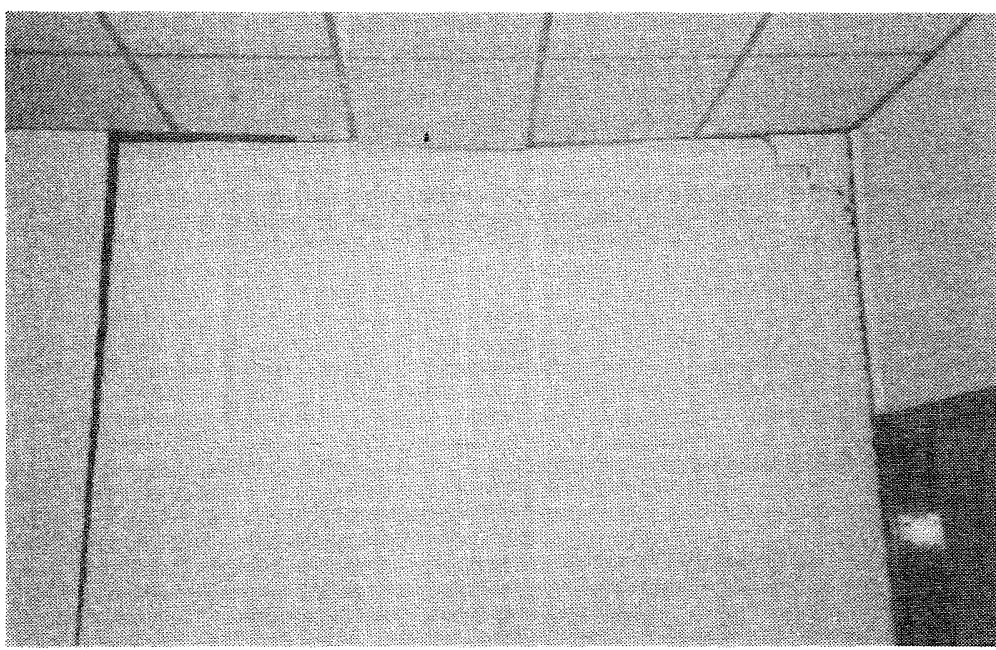




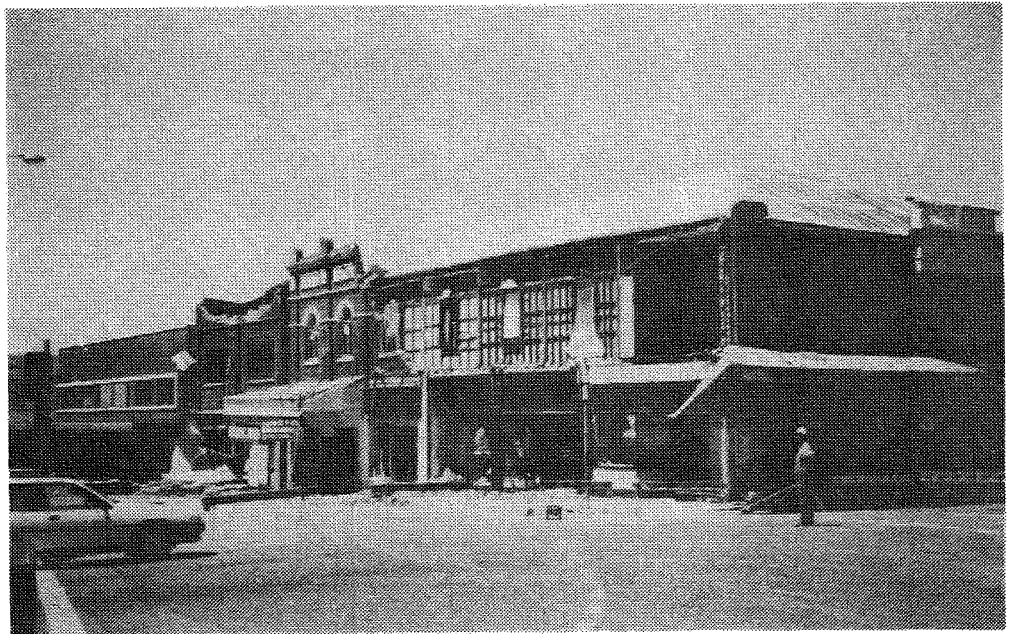

FIGURE 36

COMMERCIAL BUILDINGS, KING AND UNION STREETS, NEWCASTLE CBD: OUTER SKIN OF BRICKWORK COLLAPSED ONTO AWNING - INSIDE TIMBER FRAME SUPPORTING ROOF REMAINED IN PLACE (29.12.89; J.M.W. RYNN)

FIGURE 37 JUNCTION FAIR SHOPPING CENTRE, LOWER LEVEL CAR PARK, UNION STREET, THE JUNCTION: CONCRETE COLUMN SHEAR CRACKS AT JUNCTION WITH BEAM AND AT CENTRE POINT WHERE THERE IS LACK OF SUPPORT (5.1.90; C.R. FEATHERSTONE)

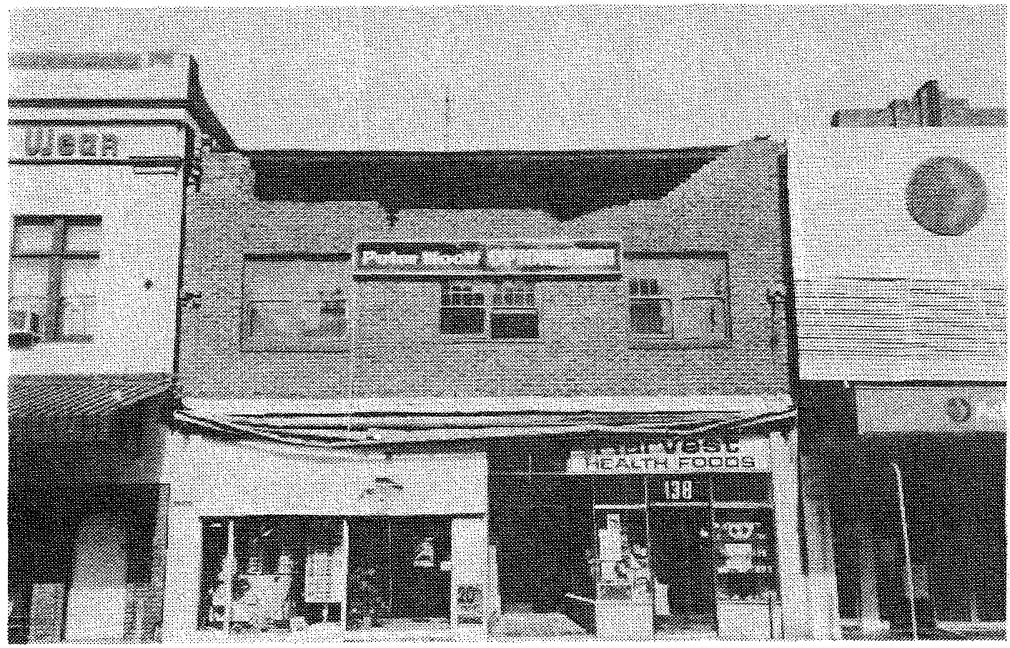

FIGURE 38

BEAUMONT STREET, HAMILTON: COLLAPSE OF UNTIED, UNREINFORCED PARAPET WHICH DEMOLISHED AWNING OVER FOOTPATH (4.1.90; C.R. FEATHERSTONE) 


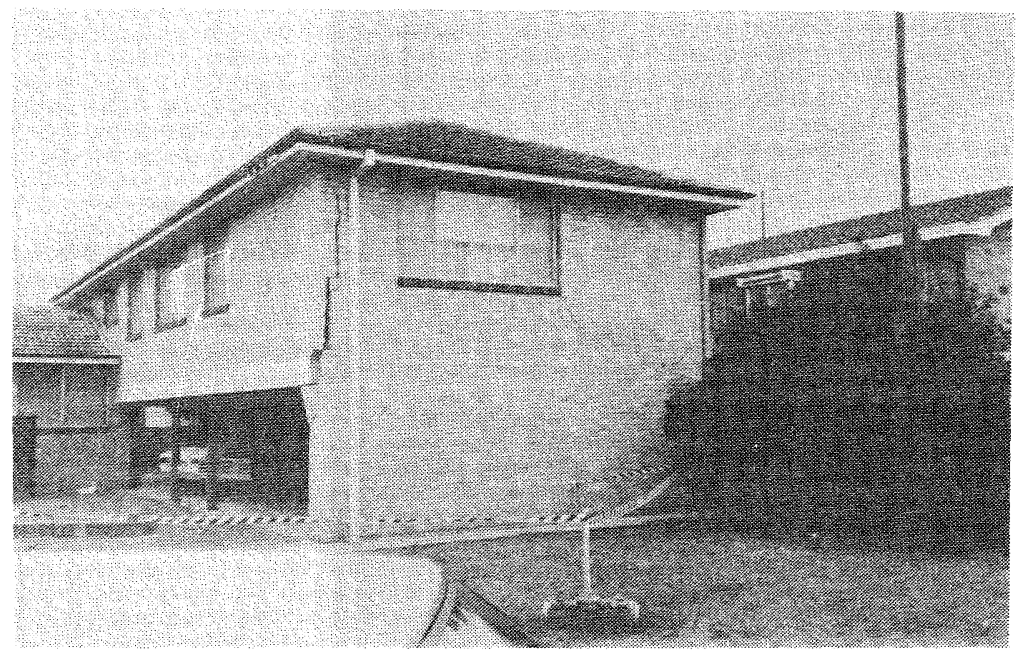

FIGURE 39 BLOCK OF UNITS, WILTON STREET, MEREWETHER: TYPICAL SOFT STOREY FAILURE - NO LATERNAL BRACING WALLS

(4.1.90; C.R. FEATHERSTONE)

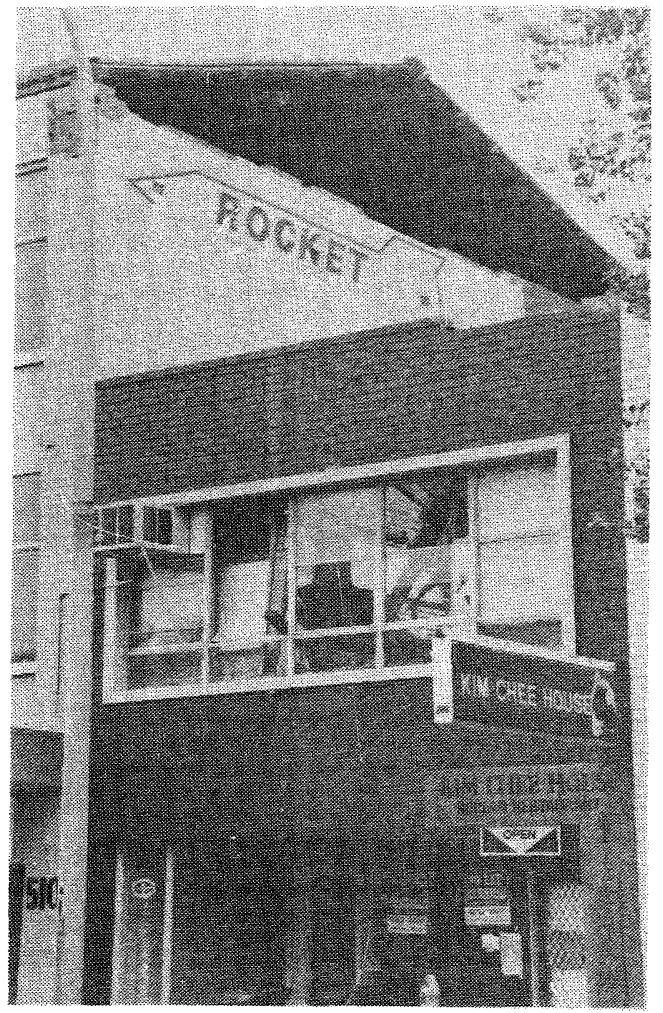

FIGURE 40 HUNTER STREET, NEWCASTLE CBD: CONSEQUENTIAL EFFECTS WHERE DEBRIS FROM UNREINFORCED MASONRY GABLE ROOF END OF HIGHER BUILDING COLLAPSED ONTO ROOF OF UNDAMAGED LOWER BUILDING UNDAMAGED BY THE INITIAL SHOCK OF THE EARTHQUAKE. DAMAGE CAUSED TO ROOF, CEILING AND INTERNAL FITTINGS OF THE LOWER BUILDING

(4.1.90; E. BRENNAN)

Private Residential Dwellings

A large proportion of the buildings damaged were domestic, not only in Newcastle and Lake Macquarie City areas, but also in the adjoining cities and shires. The situation was similar to that for the commercial built environment, with age and the apparent lack of maintenance being major factors in the destruction. Patterns of damage ranged from complete failure of walls and roofs, failure of various building attachments and cracking in walls and ceilings, to costly damage to internal fittings, family heirlooms and to household contents. This clearly created major issues for assessment by the insurance industry and welfare agencies.

A selection of photographs of such damage is given in Figures 41-45. 


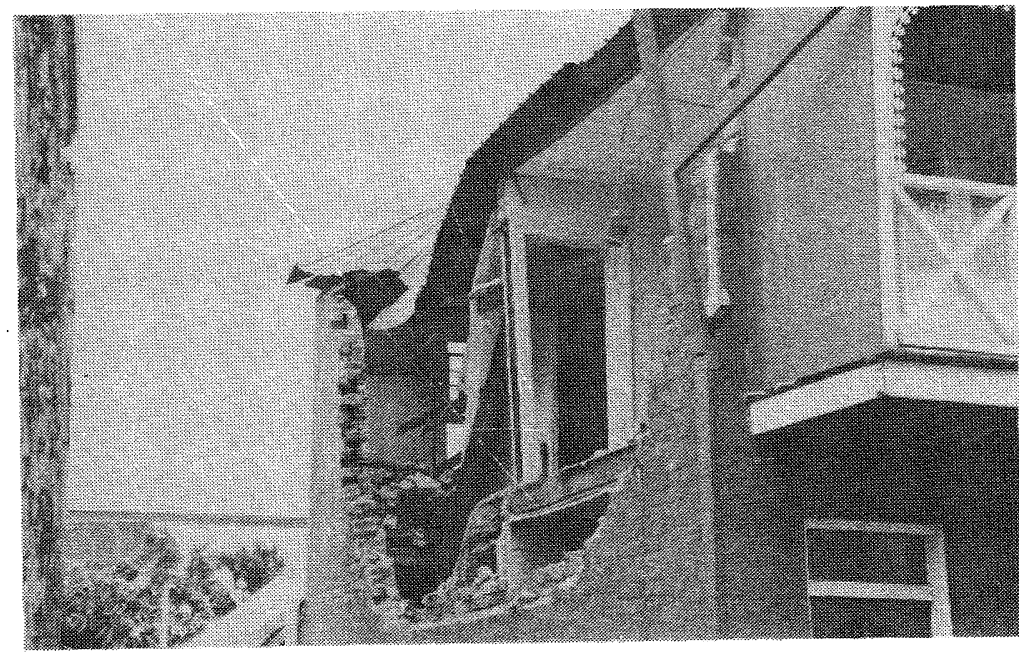

FIGURE 41

TERRACE HOUSE, LAMAN STREET, COOKS HILL: COLLAPSE OF DOUBLE SKIN BRICK WALL AND BRICK GABLE END WITH NO LATERAL SUPPORT OF TWO-STOREY PRIVATE DWELLING, TYPICAL DAMAGE FOR THIS TYPE OF CONSTRUCTION (5.1.90; C.R. FEATHERSTONE)

FIGURE 42 TERRACE HOUSE, LAMAN AND JOHN STREETS, COOKS HILL: FAILURE CRACKS ALONG LINES OF LEAST RESISTANCE. NOTE FAILURE ON PARAPET AND AROUND LINTEL. DAMAGE SO SEVERE THAT DWELLING WAS DEMOLISHED (5.1.90; C.R. FEATHERSTONE)
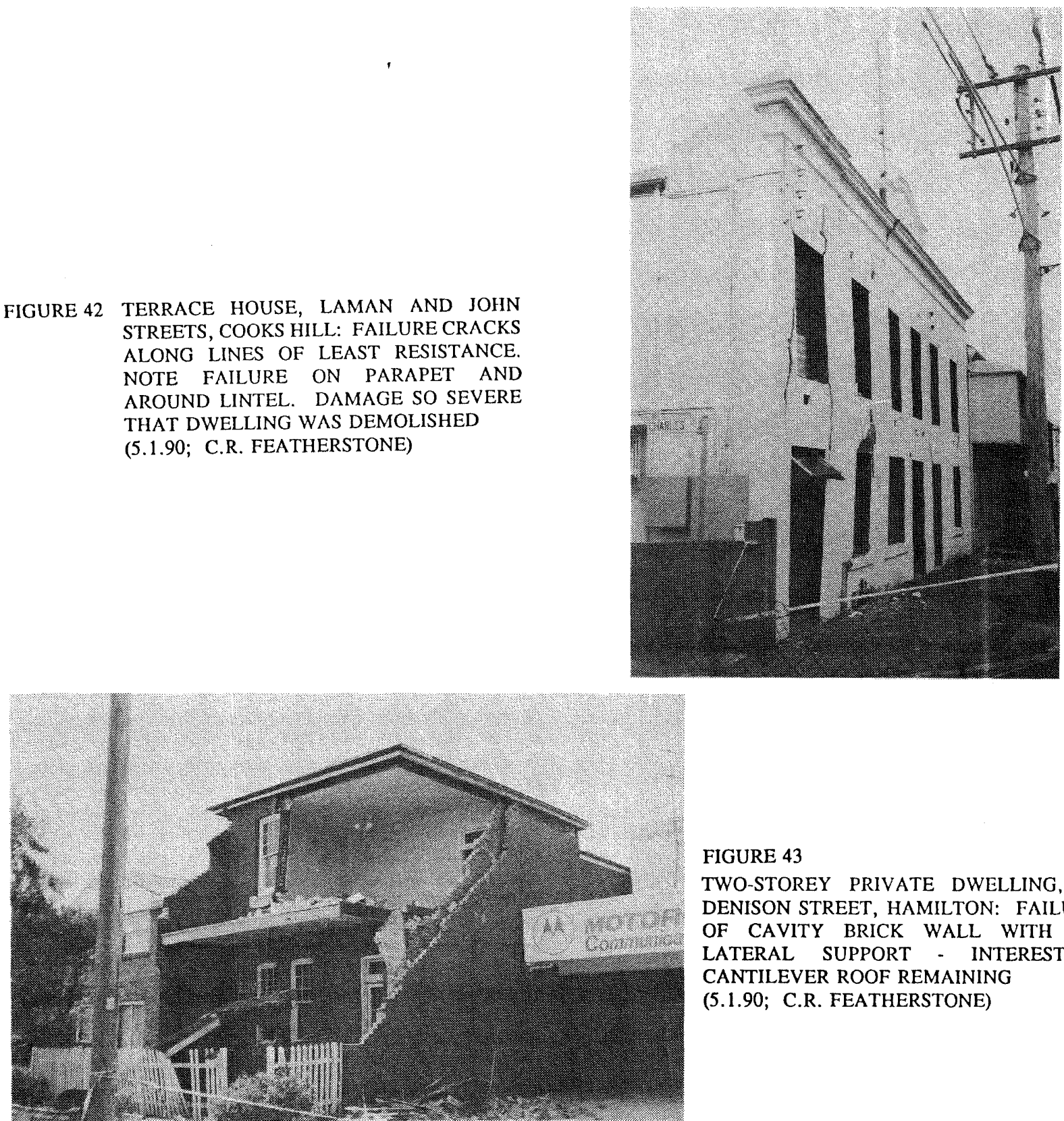

FIGURE 43

TWO-STOREY PRIVATE DWELLING, 49 DENISON STREET, HAMILTON: FAILURE OF CAVITY BRICK WALL WITH NO LATERAL SUPPORT - INTERESTING CANTILEVER ROOF REMAINING (5.1.90; C.R. FEATHERSTONE) 


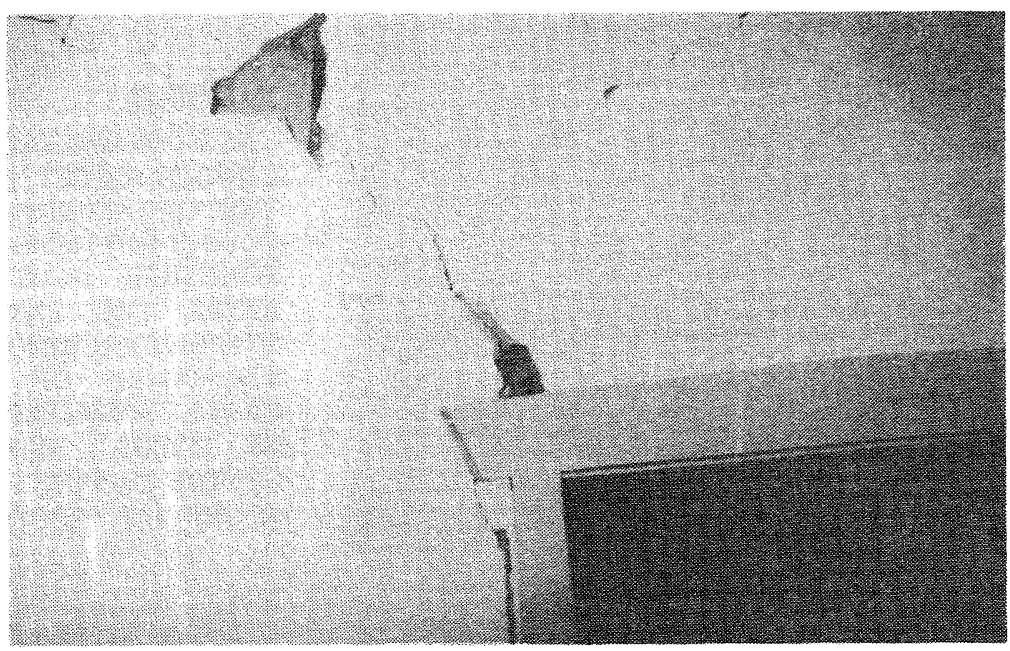

FIGURE 44 INTERIOR OF SINGLE STOREY PRIVATE DWELLING, 91 MEREWETHER STREET, MEREWETHER: TYPICAL DIAGONAL SHEAR FAILURE IN UNREINFORCED MASONRY WALLS (BRICK AND CEMENT RENDER) FROM DOOR OPENING IN INTERNAL WALL SHEETING (4.1.90; B. GREEN)

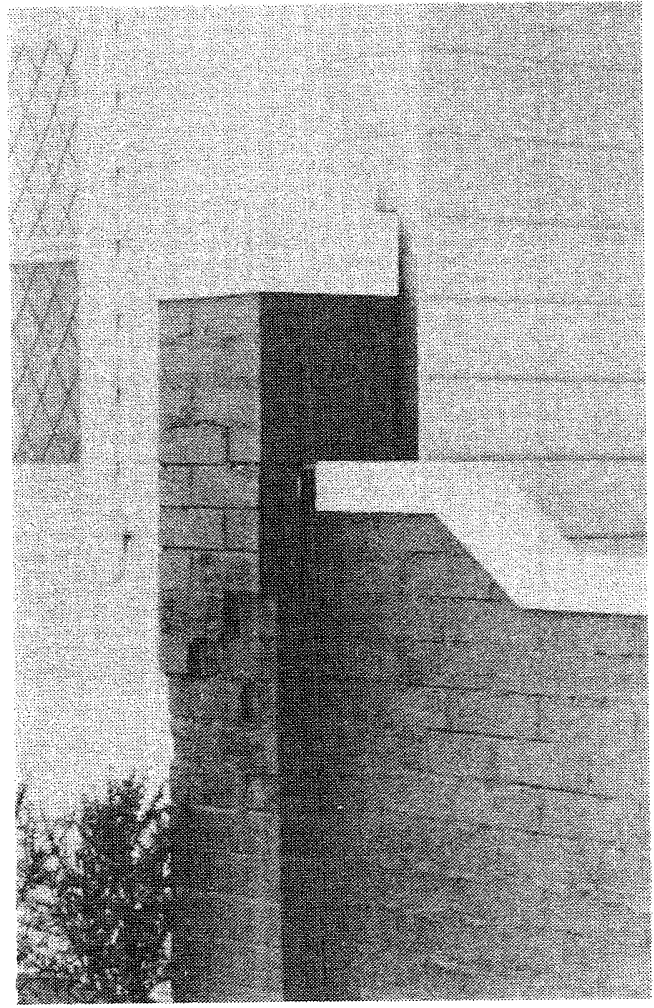

FIGURE 45 EXTERIOR BRICK VERANDAH OF PRIVATE SINGLE STOREY DWELLING, 151^ OLD MAITLAND ROAD, HEXHAM (APPROX 14 $\mathrm{km}$ NW OF NEWCASTLE CBD): DISCONNECTED UNSUPPORTED BRICK PIER FAILURE WITH SEVERE CRACKING OF MORTAR JOINTS AND DISPLACEMENT OF BRICK BASE

(21.1.90; E. BRENNAN)

\section{Churches and Related Institutional Buildings}

More than 600 religious institutions, churches, schools and associated residences, within the epicentral region and at locations up to about $200 \mathrm{~km}$ distant from Newcastle suffered (J. Nichols in [8]). The most seriously affected were the more than 350 complexes concentrated mainly in the Newcastle area. While the damage was typical for unreinforced masonry in all buildings, the nature of churches "shell-like" designs have been shown to be an added consideration because of shear failures. Some effects, specific to churches, included the fall of religious statues (at Sacred Heart and St Josephs, Newcastle), toppling of spires, finials and crosses (St Andrews and Christ Church Cathedral, Newcastle) and structural damage to bell towers (St Josephs and Hamilton Wesley Church, Newcastle).

A selection of photographs of damage to church structures is given in Figures $46-48$ 


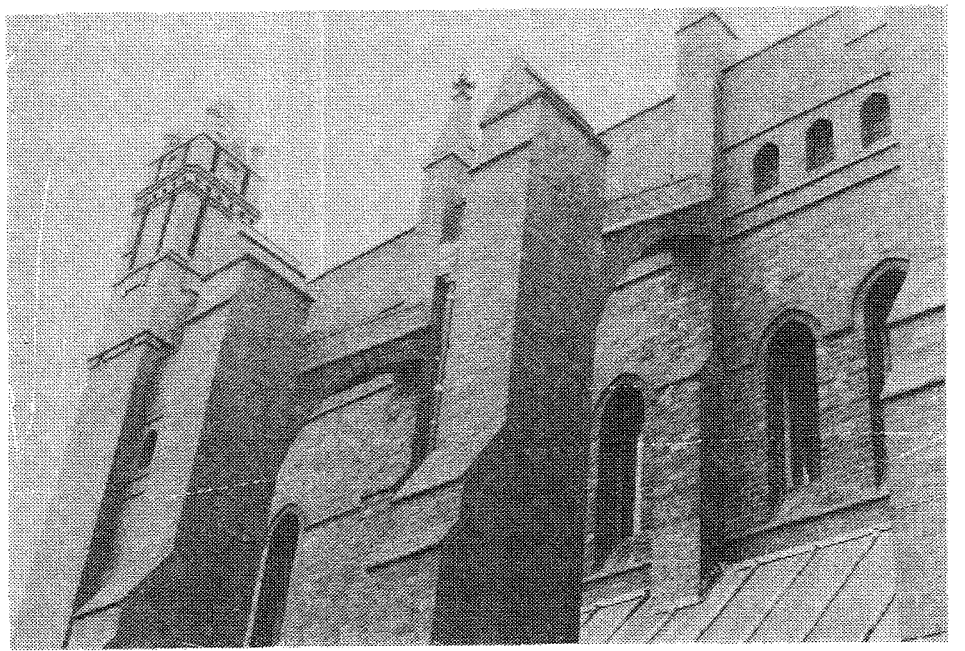

FIGURE 46

CHRIST CHURCH ANGLICAN CATHEDRAL, CHURCH STREET, NEWCASTLE: SEPARATION OF UNREINFORCED BRICKWORK IN FLYING BUTTRESSES WHICH WERE TIED TOGETHER WITH METAL STRAPPING AFTER THE EARTHOUAKE DAMAGE. SEVERE CRACKING IN BRICK SHELL-LIKE STRUCTURE OF CHURCH. MAJOR CRACKS WITH DISPLACEMENT IN BRICKS OF SPIRES. FINIALS ROTATED ON CENTRE SUPPORTS

(4.1.90; J.M. FENWICK)

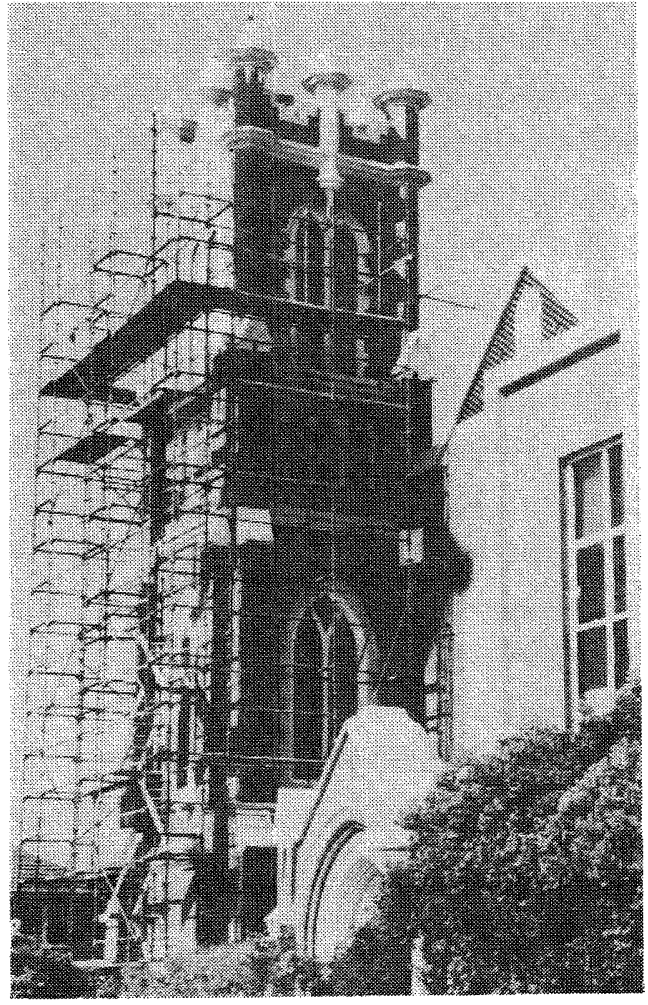

FIGURE 47 WESLEY CHURCH, BEAUMONT AND DENISON STREETS, HAMDILTON: LOAD BEARING MASONRY CHURCH TOWER SEVERE DAMAGE TO TYPICAL MASONRY AND ARCHITECTURAL FEATURE, INCLUDING DAMAGE TO STAINED GLASS WINDOWS

(4.1.90; C.R. FEATHERSTONE)

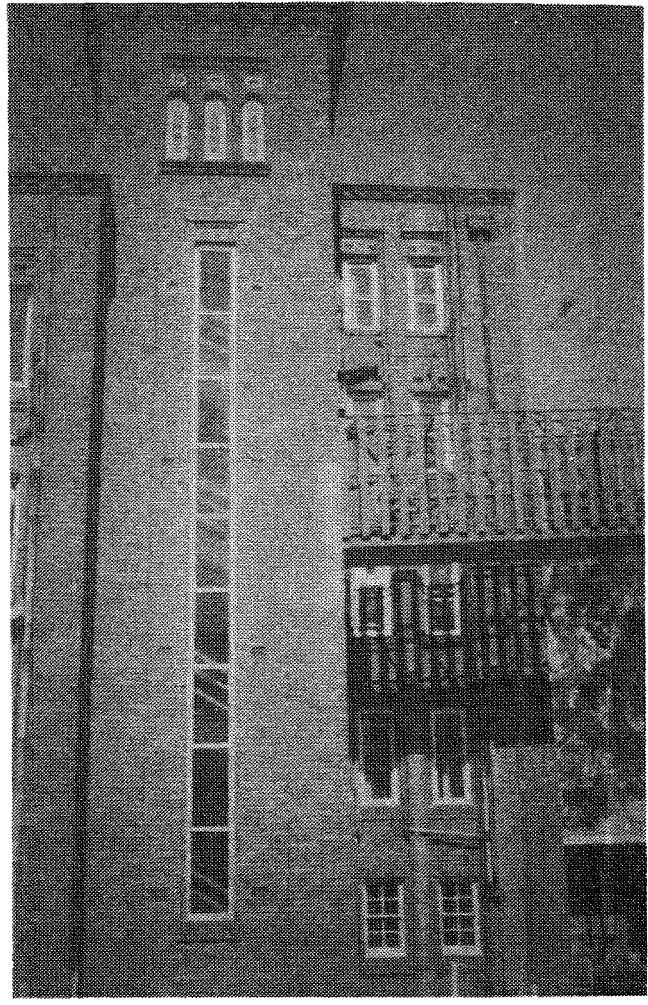

FIGURE 48 ST MARY'S CATHOLIC HIGH SCHOOL REDGAMMON BUILDING, MAITLAND (CIRCA 1930's): BRIDGE DISCONNECTED AND PARAPET MOVED 30-80 mm (WEST VIEW) (JANUARY 1990; J. NICHOLS) 


\section{FIGURE 49}

STOCKTON BRIDGE (HUNTER RIVER, NORTH CHANNEL): SETTLEMENT OF $\triangle B O U T 70 \mathrm{~mm}$ OF WESTERN APPROACH ABUTMENT EVIDENCED BY BITUMEN INFILL ON ROADWAY (PLACED SINCE EARTHQUAKE) AND CRACKED AND DISPL $\Lambda$ CED CONCRETE MEDIAN STRIP (29.12.89; J.M.W. RYNN)

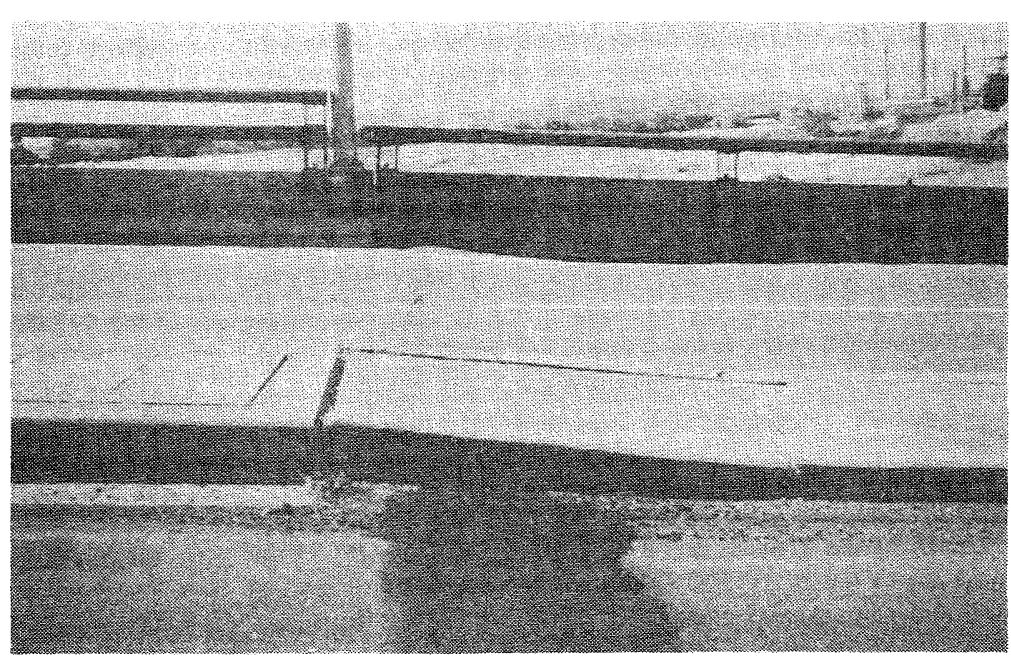

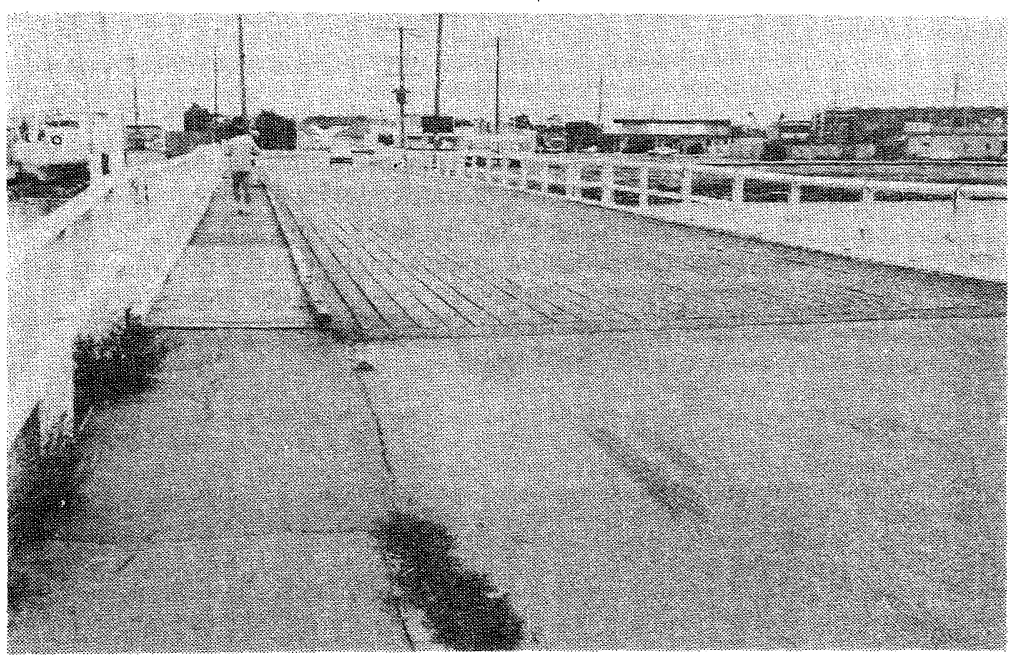

\section{FIGURE 50}

COWPER STREET BRIDGE, CARRINGTON, (ACROSS THROSBY CREEK): DROP OF LESS THAN $50 \mathrm{~mm}$ IN WESTERN ABUTMENT (INDICATED BY BITUMEN INFILL PLACED SINCE THE EARTHQUAKE) AND ABUTMENT SHOULDERS. EVIDENCE OF MANY FRESH CRACKS IN BITUMEN AND GRASS (LOWER LEFT QUADRANT) (5.1.90; C.R. FEATHERSTONE)

\section{Bridges}

Clear evidence of ground consolidation from ground shaking was shown in the western approach abutment of the Stockton Bridge (a long concrete arch structure over the north channel of the Hunter River) of about $70 \mathrm{~mm}$ (Figure 49). It would appear that settlement in the sands of the western bank of the Hunter River due to abutment loading had occurred. Some evidence of only slight movement (less than $50 \mathrm{~mm}$ ) in the western abutment of the Cowper Street Bridge, an old wooden bridge across Throsby Creek at Carrington, was also observed (Figure 50).

\section{Infrastructure}

As an immediate consequence of the earthquake, the only major disruption reported was to the electricity supply. At the Killingworth switching station, several porcelain insulators supporting $132 \mathrm{kV}$ circuit breakers failed thus causing transformers to be disconnected. Power supply was generally restored to essential industrial and domestic users about four hours after the earthquake. Many buildings were totally disconnected from the supply for safety reasons. This naturally had consequences for facilities relying on both high and low voltage supplies, specifically for communications, industries requiring pumps and transportation systems and heavy industrial complexes (such as collieries, BHP Steel Works, Tomago aluminium smelter and railways). However, emergency power systems where available, were brought into operation within a short time for safety reasons.

No immediate damage was observed in the water, sewerage or gas underground systems. It has, however, become evident in the time since the earthquake, that damage to all of these and other services have occurred on a wide and costly scale. Leakage from water pipes and a $375 \mathrm{~mm}$ diameter main has shown pipe fractures and joint splitting. Minor cracking was reported in several water storage reservoirs and tanks in the region. With the sewerage system, there has been an increase in sediment infiltrating into the treatment works indicating fractures and failures of the underground mains. Up to six months following the earthquake, seepage was observed on the ground surface around service drains and subsidence occurred in those suburbs of Newcastle having alluvial type soils. Reports of gas leaks indicating cracking in the underground pipe network have occurred since the earthquake. 
No immediate damage to railway track or electric cable (for electric and diesel trains) systems was observed. Damage was sustained to many associated railway buildings and structures similar to other buildings in the epicentral area, including signal boxes (elevated structures) in the CBD (Central, Hamilton and Wickham stations) and at Woodville (near Maitland, about 30 $\mathrm{km}$ WNW of Newcastle), to an overbridge at Tighes Hill and employees' residences. The railway system was inoperative immediately following the earthquake due to electrical signal and communications power failure. Inspections on tracks, rolling stock and associated facilities were undertaken.

\section{Fire}

Only one fire was reported at the time of the earthquake. This occurred at the Newcastle TAFE College, Tighes Hill in the third (top) floor of the Science Block as a result of a chemical spill in a laboratory (Figure 51).

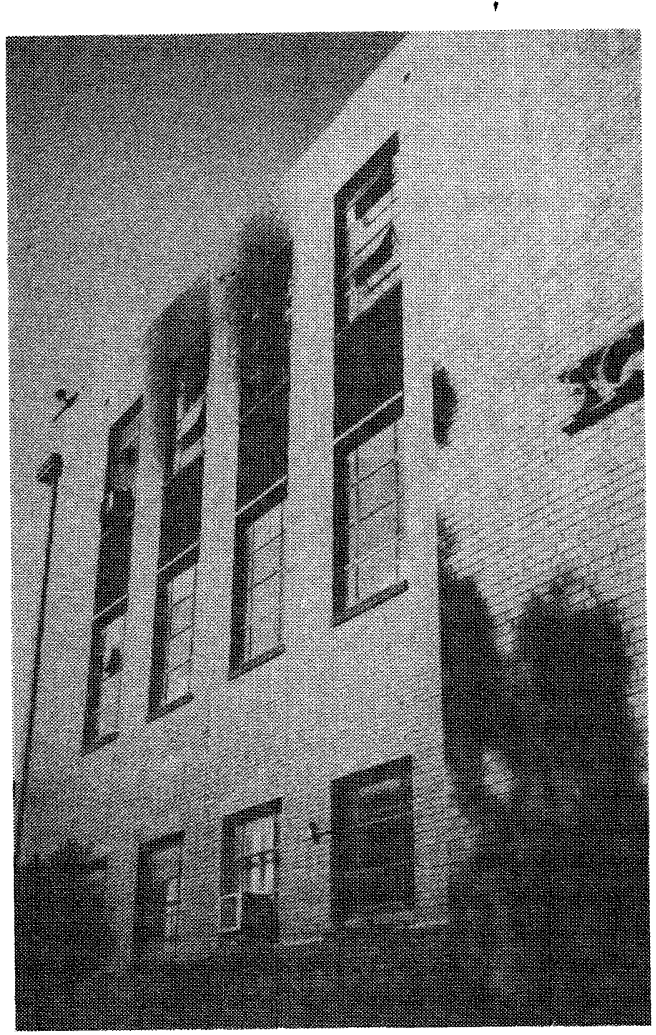

\section{Other Interesting Affects in Epicentral Region}

Many observations of other specific, yet significant, affects resulting from the earthquake have emerged in the analysis of the field survey felt reports. These included reports of actual wave motions of the ground surface and observations of motions at sea and on lakes. Many reports of unusual animal and bird behaviour (both domestic and wild) were received. This is a very common affect associated with earthquakes in all parts of the world (although no scientific explanation exists for the phenomenum). The following is a brief summary of some of the more unusual observations reported within about $50 \mathrm{~km}$ around Newcastle, from the northern areas of Port Stephens to the southern parts of Lake Macquarie.

\section{Ground motions}

Observations of ground (or surface) waves were reported from several golf courses and bowling greens generally in the Newcastle - Lake Macquarie region and in several streets in the suburbs of Hamilton and Mayfield. Evidence of such ground motions was observed in the apparent displacement of a brick footpath (Figure 52) and adjacent roadway gutter (Figure 53) in King Street, Newcastle CBD.

Ground motions were also confirmed by drivers of many cars. More than 60 reports were received with effects varying from "lost control of vehicle" to" felt like a bump in the road". Such effects were experienced in the Hamilton - Mayfield - Lambton - Adamstown area, Newcastle CBD - Cooks Hill area and at Charlestown, about $10 \mathrm{~km}$ south of these Newcastle suburbs.

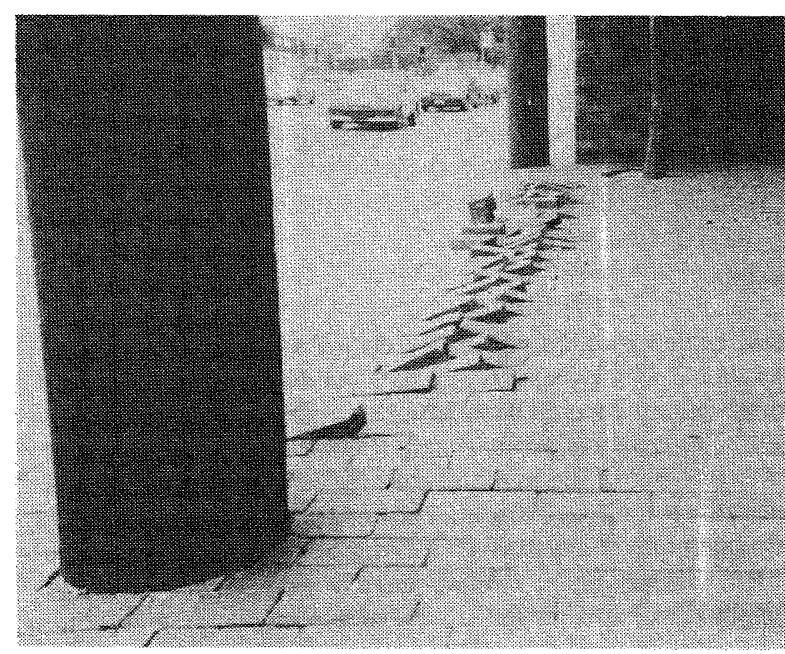

FIGURE 52 EVIDENCE OF APPARENT COMPRESSIVE GROUND MOTION IN BRICK PAVEMENT OUTSIDE DEPT OF SOCIAL SECURITY BUILDING IN KING STREET, NEWCASTLE CBD (5.1.90; W.H. BOYCE) 


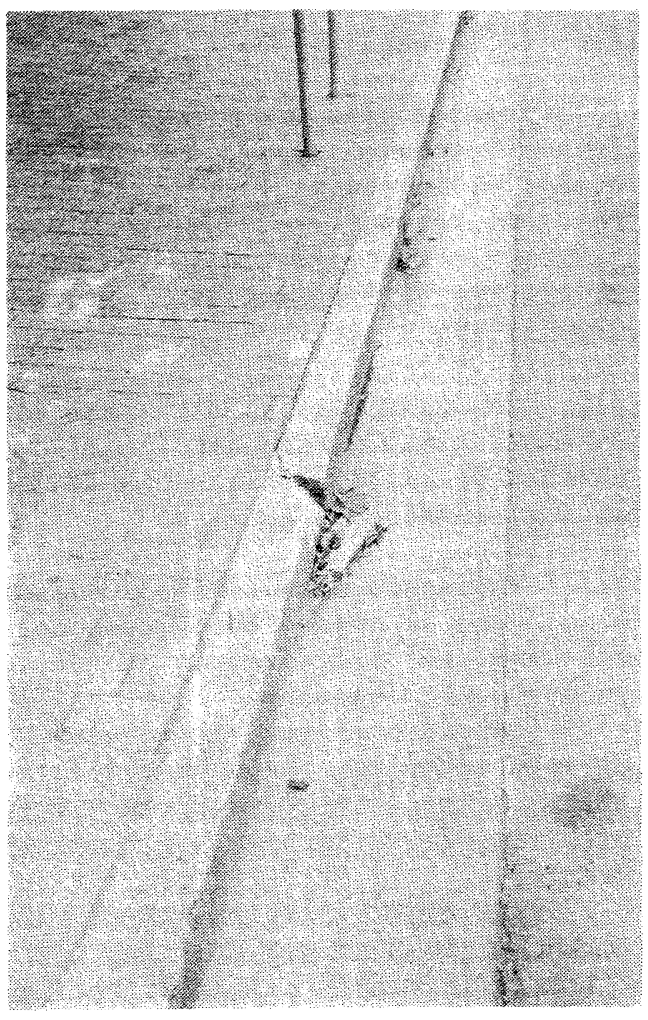

FIGURE 53 FURTHER EVIDENCE SHOWING COMPRESSION FAILURE (CRACK) IN STREET GUTTER AND SPALLING OF CONCRETE ON KERB EDGE OF BRICK PAVEMENT OF FIGURE 52 (5.1.90; W.H. BOYCE)

\section{Ships at sea}

Five large vessels off the Port of Newcastle, including two container ships and a coal carrier, reported high-frequency vibration of the vessels, the like of which all captains had never experienced before (Captain N.Morrison, MSB Hunter Ports Authority, pers. comm., 1990). Two of these ships were in motion about three to four nautical miles east of Nobby's Head, the "ARITA" coming into port and the "SOUTHERNWEALTH" leaving port, and a third, the coastal coal carrier "WALLARAH" steaming northeast about two nautical miles south of Redhead Point. Two others, the "SOARERDIANA" and "LIKA" were anchored near the Inner and Outer Markers, about four nautical miles east of Nobby's Head.

About one nautical mile southeast of the Port Stephens light, the MV "BAYSIDE 1", a 24-foot Huntsman-type fibreglass vessel, reported "about $10.30 \mathrm{am}$ suddenly cavitated causing the motor to (over) rev ... travelling with a following sea". Damage to the motor was such that the vessel had to be towed into Port Stephens (S. Gaffett, pers. comm., 1990). In Port Stephens, a yacht anchored in Fame Cove reported slight vibration of the vessel and a small runabout in North Arm Cove touched oyster beds, both at the time of the earthquake. The locations are shown in Figure 54.
Several reports from owners of small dinghies and runabouts who were fishing in various areas close to the coastline and in Lake Macquarie (for example: within a few hundred metres of Nobby's Head, in the Swansea Channel, just to the east of Swansea, on the reef east of Swansea Heads), in several small bays in Port Stephens and near Boondelbah Island just east of Port Stephens, stated that no effects were noticed at the time of the earthquake.

\section{Divers on the seabed}

The earthquake's effects were also experienced by divers on the seabed at two locations (Figure 54):

(a) About $3 \mathrm{~km}$ south of Fingal Bay (Port Stephens area, water depth about $50 \mathrm{~m}$ ), two divers ".. at the bottom of the ocean .. heard a rumble and felt a vibration pass through their bodies (and) seeing nothing unusual on the sea floor, supposed that a helicopter had hovered above the surface ... " (T. Smythe, Newcastle "Herald", 1990);

(b) Two people were diving on the wreck of the "DAVENPORT" in Stockton Bight in about $10 \mathrm{~m}$ of water when they experienced a great vibration (of the wreck in the sand) which lasted for a few seconds and thought a ship had passed overhead (G.Southern, pers. comm., 1990).

\section{Surf}

Several reports from surfers and boardriders at Bar Beach, Redhead Beach and Caves Beach (Newcastle - Lake Macquarie area) noted that, at the time of the earthquake, two large waves suddenly appeared on the fairly flat surf (Figure 54). At Redhead Beach, the surf also became suddenly very rough with many waves closer together than normal (K. Hilton, pers. comm.,1990).

\section{Beaches}

Reports of the effects were received from several people at (Figure 54):

(a) Stockton Beach: sand seemed to be "rolling to the north" with person sitting on a low beach chair overturned and children sitting in a circle "bumped heads together";

(b) Nobby's Beach: "sand slightly rippled as if something was being pulled along under its top layers"; "following the vibration, the waves (which were not very large) stopped rolling and the sea went calm like a lake for a few seconds, then the waves began again";

(c) Newcastle, Beach: rapid vibrations felt in the sand; rock fell from cliff just to the south of the main pavilion;

(d) Bar Beach: rippling effect felt through the sand;

(e) Redhead Beach: strong vibrations of the sand experienced; from the bluff just north of the beach (Redhead Point), a rock fall was found at the base of the cliff and very fine cracks observed along the top of the headland;

(f) Caves Beach: "sensation of the sand being shifted from below";

(g) One Mile Beach (Anna Bay, Port Stephens area): "feeling of motion of the sand coming through the feet"; no effects observed on the water itself. 


\section{Effects on Lake Macquarie}

Many reports of several different effects on Lake Macquarie were received from people in boats. These included (Figure 54):

(a) On the southern side of Pulbah Island there was a change in the "drift: from south-to-north to north-to-south at 10.30am on the day";

(b) Around Pulbah Island there was a series of ripples observed coming from the north which, in striking the island, radiated out from it;

(c) In several parts of the Lake, small fishing dinghies experienced a "rippling" along the bottom of the boat as if going over a very shallow rocky bottom;

(d) Unexplained waves observed in several parts of the lake with the feeling in the boats of "being on a bowl of shaking jelly";

(e) Near Valentine (northeastern parts of the Lake) the water was "splashing-up as if fish were chomping";

(f) Seiches of up to 1 metre were reported from the shores in the northern parts of the Lake.

\section{Bubbles at sea}

Local fishermen reported the presence of (gas) bubbles rising from the sea in an area about $3 \mathrm{~km}$ south of Cemetery Point (Figure 54). These were first observed a few hours after the earthquake and continued for a few weeks thereafter. Unfortunately no samples were taken for chemical analyses and their origin remains a mystery.

\section{Collieries}

Although the surface installations at most of the collieries in the Newcastle area suffered damage like any other building, no major damage has been reported from the underground workings. There were, however, several significant effects reported underground (information kindly supplied by the Joint Coal Board through Mr. A.R. Vaughan, pers. comm., 1990), as briefly listed in Table 5 .

All reports from underground miners included having felt vibrations and/or heard a rumbling noise but put this down to either some kind of explosion or collapse in some other part of the mine. Two specific reports are noted:

Teralba (A. Reynolds, pers. comm., 1990) - ground was moving sideways shaking the pillars of coal; continuous miner was rocking back and forth; Lambton (B. Hilton, pers. comm.,1990, 1991) (Figure 54) -

BH -Located at 4 South Panel, approximately $1.5 \mathrm{~km}$ off the coast at $70 \mathrm{~m}$ under the sea (Borehole Seam); severe shaking of area, small pieces of stone dislodged from roof, very loud, sudden noise and persons thrown off balance;

JC - Located at BL2 Panel, just off the coast; severe shaking of ground and very loud noise;

DT - Located just below the pit top; loud noise like methane gas explosion.

Of note was the major and very serious ingress of water at this mine, an increase of about 6 times that normally experienced prior to the earthquake. This high rate of inflow continued for several months. The water was fresh and did not represent a fracture to the sea.

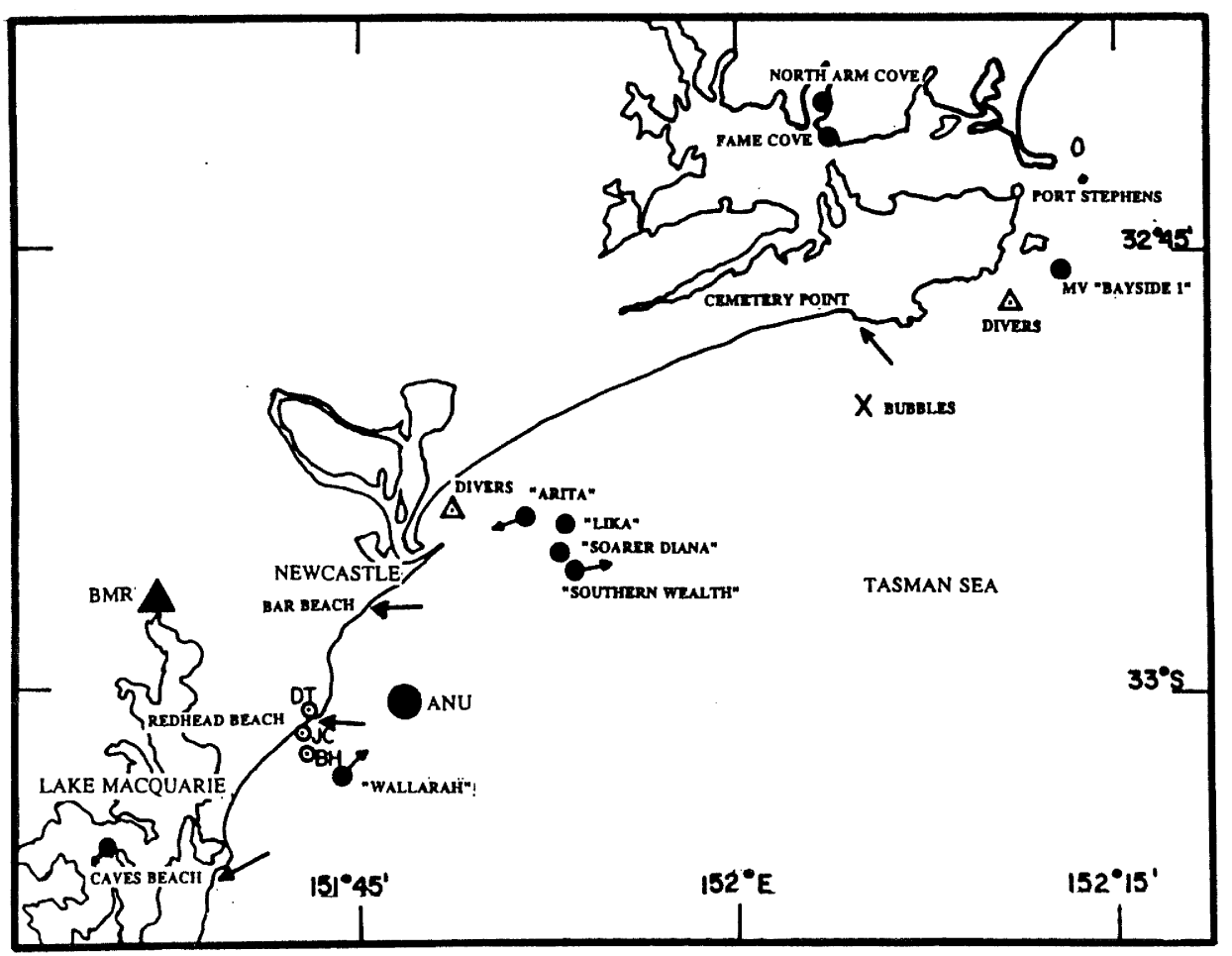

FIGURE 54 EFFECTS AT SEA, ON THE COASTLINE AND IN UNDERGROUND COAL MINES IN THE EPICENTRAL REGION OF THE 1989 NEWCASTLE EARTHQUAKE 


\section{TABLE 5 EFFECTS IN UNDERGROUND COLLIERIES}

Key to damage underground

(i) Damage reported : 1 Fall of roof

2 Spalling of ribs

3 Ingress of water

4 Vibrations felt

(ii) Damage to : A Drift installations

B Shaft wall

C Shaft installations

D Conveyor belt roads

E Main roads

F Return airways

$\mathrm{G}$ Loss of production

\begin{tabular}{||l|c|c|c||}
\hline \multicolumn{1}{||}{ Colliery } & $\begin{array}{c}\text { Epicentral } \\
\text { Distance }(\mathrm{km})\end{array}$ & \multicolumn{2}{|c|}{ Damage Underground } \\
\hline Teralba & 2 & $1,2,3,4$ & A,B,C,G \\
West Wallsend & 5 & $2,3,4 \mathrm{G}$ & \\
Gretley & 7 & $1,3,4 \mathrm{D}$ & \\
Lambton & 10 & 3 (major),4 & G \\
Awaba & 12 & none & \\
Myuna & 15 & none & \\
Cooranbong & 15 & none & \\
Bloomfield & 20 & none & \\
Chain Valley & 23 & none & \\
Newvale No.1 & 23 & 4 & \\
Wyee & 23 & none & \\
Moonie & 23 & & E,F,G \\
Munmorah & 28 & & G \\
Ellabong & 30 & 2 & G \\
Newvale No.2 & 30 & 3 & \\
\hline
\end{tabular}

\section{Damage at Some Distance from the Epicentre}

Damage was sustained by many buildings outside the epicentral region of Newcastle - Lake Macquarie. This was most severe in the Upper Hunter Valley around the Maitland area (about 30 $\mathrm{km}$ northwest of Newcastle). This included major cracking in unreinforced masonry (brick and concrete walls and chimneys) and many cases of breakage of household contents. Similar minor damage (cracking of masonry) occurred up to $250 \mathrm{~km}$ north of Newcastle from Scone (Figure 9) to Kempsey and up to $150 \mathrm{~km}$ south from the Wyong-Gosford area to Sydney (Figure 10).

\section{ASSIGNED INTENSITIES AND ISOSEISMAL MAPS}

Whereas earthquake source mechanisms are the causal effect in defining patterns of damage, assigned intensity values can be considered as the resultant effects. Consequently, due care must be exercised in assigning such values to the damage reports to maintain a reliable and consistent standard. In Australia, intensity values are based on the Modified Mercalli(MM) Scale of Earthquake Intensity, New Zealand Version, 1965 [55]. As MM intensity is one primary parameter in providing physical (albeit empirical) relationships in earthquake engineering (not every region has the luxury of instrumental acceleration data), questions have been raised as to the possible need to modify Eiby's (1966) Scale for Australian conditions.
The 1989 Newcastle earthquake allows the first comprehensive "test" of this MM Scale for use with Australian masonry construction standards. The extensive data set, for both the near- and far-fields, provides for the first time, an excellent basis by which the relevance of specific MM values, particularly for severe damage MM VI - IX, can be ascertained. This section represents a progress report of the continuing research on this aspect conducted with several engineers (I Pedersen, Newcastle; W Boyce, Brisbane; J Binney, Melbourne; pers. comm. 1990, 1991).

From the study thus far, it is considered that modifications are not required for Eiby's (1966) MM Scale per se, but rather for the definition of masonry conditions to suit Australian construction standards given in his "Categories of Non-wooden Construction". This relates particularly to Eiby's definition of "reinforced" where it would seem prudent now to extend his Masonry B by B1 and B2 to encompass three categories, as indicated in Table 6. Although this could not strictly be used in the application of Eiby's (1966) Scale, it was subjectively considered in assigning MM values to the Newcastle earthquake damage. Table 6 gives the categories (abridged) with some examples for Newcastle building damage.

TABLE 6 CATEGORIES OF NON-WOODEN CONSTRUCTION (BASED ON [55])

\begin{tabular}{|c|c|c|}
\hline CATEGORY & DEFINITION & NEWCASTLE EXAMPLE \\
\hline Masonry A & $\begin{array}{l}\text { Structures designed to resist } \\
\text { lateral (earthquake) forces of } \\
\text { about } 0.1 \mathrm{~g}\end{array}$ & None \\
\hline Masonry B & $\begin{array}{l}\text { Reinforced buildings of good } \\
\text { workmanship with some } \\
\text { mortar, not designed to resist } \\
\text { lateral forces }\end{array}$ & Taxation Building \\
\hline B1 & $\begin{array}{l}\text { Reinforced frame with } \\
\text { masonry infill panels }\end{array}$ & John Hunter Hospital \\
\hline B2 & $\begin{array}{l}\text { Reinforced frame with } \\
\text { unreinforced masonry infill } \\
\text { panels. }\end{array}$ & $\begin{array}{l}\text { Workers' Club } \\
\text { George Hotel }\end{array}$ \\
\hline Masonry C & $\begin{array}{l}\text { Buildings of ordinary work- } \\
\text { manship, mortar of average } \\
\text { quality, no extreme } \\
\text { weaknesses, not designed or } \\
\text { reinforced to resist lateral } \\
\text { forces }\end{array}$ & $\begin{array}{l}\text { TAFE, Tighes Hill } \\
\text { Junction Motor Lodge } \\
\text { Kent Hotel } \\
\text { Carrington Chambers } \\
\text { Christ Church Cathedral } \\
\text { Soft-storey structures } \\
\text { Newer Residential } \\
\text { Dwellings (post 1960) }\end{array}$ \\
\hline Masonry D & $\begin{array}{l}\text { Buildings of low standards of } \\
\text { workmanship, poor mortar }\end{array}$ & $\begin{array}{l}\text { Older Residential Dwellings } \\
\text { (pre 1960) }\end{array}$ \\
\hline
\end{tabular}

In assigning $\mathrm{MM}$ values to the damage reports cognisance was taken of the engineering aspects of design, construction materials, construction methods and maintenance. No account was taken in those buildings which may have been designed for lateral forces in terms of the requirements of the wind loading code. Table 7 gives the criteria used for each MM level in[55] with examples of such assignments for damaged buildings in Newcastle.

A maximum intensity, $I_{o}$, was assigned at MM IX to three buildings in the Newcastle CBD. Several instances of MM VIII occurred in the Newcastle City area. MM VI was widespread encompassing Newcastle and Lake Macquarie Cities, Upper Hunter (for example: Maitland and Cessnock) and in the Port Stephens Shire. 
TABLE 7 MM INTENSITY VALUES ASSIGNED TO DAMAGE AND OTHER EFFECTS FROM 1989 NEWCASTLE EARTHQUAKE

\begin{tabular}{|c|c|c|c|}
\hline \multirow{2}{*}{ MM } & \multirow{2}{*}{$\begin{array}{l}\text { CRITERIA } \\
\begin{array}{l}\text { Masonry C heavily damaged } \\
\text { sometimes collapsing completely }\end{array}\end{array}$} & \multicolumn{2}{|l|}{ NEWCASTLE AREA } \\
\hline & & $\begin{array}{l}\text { Worker's Club } \\
\text { George Hotel } \\
\text { Newcastle RSL }\end{array}$ & \\
\hline VIII & $\begin{array}{l}\text { Masonry B damaged in some cases } \\
\text { Masonry C damaged, with partial } \\
\text { collapse } \\
\text { Panel walls thrown out of frame } \\
\text { structures } \\
\text { Chimneys, monuments brought down } \\
\text { or twisted } \\
\text { Brick veneers damaged } \\
\text { Steering of motor cars affected }\end{array}$ & $\begin{array}{l}\text { Kent Hotel } \\
\text { John Hunter Hospital } \\
\text { Christ Church Cathedral } \\
\text { Shops on corner of King and } \\
\text { Union Streets } \\
\text { TAFE, Tighes Hill } \\
\text { Junction Motor Lodge } \\
\text { Century Theatre } \\
\text { Soft-storey structures } \\
\text { School }\end{array}$ & \\
\hline VII & $\begin{array}{l}\text { General alarm } \\
\text { Noticed by drivers of motor cars } \\
\text { Masonry C few instances of damage } \\
\text { Masonry D cracked and damaged } \\
\text { Unbraced parapets and architectural } \\
\text { ornaments fall } \\
\text { Loose brickwork and tiles dislodged } \\
\text { Weak chimneys broken at roof line } \\
\text { Large bells ring } \\
\text { Trees and bushes shaken strongly }\end{array}$ & $\begin{array}{l}\text { Hamilton RSL Club } \\
\text { Soft-storey structures } \\
\text { Newer Residential } \\
\text { Dwellings (post 1960) } \\
\text { Older Residential } \\
\text { Dwellings (pre 1960) }\end{array}$ & \\
\hline VI & $\begin{array}{l}\text { Felt by all } \\
\text { People and animals alarmed } \\
\text { Masonry D slight damage } \\
\text { Plaster cracks and falls } \\
\text { Windows, glassware, crockery } \\
\text { broken } \\
\text { Objects fall from shelves } \\
\text { Pictures fall from walls } \\
\text { Heavy furniture moved } \\
\text { Trees and bushes shake }\end{array}$ & $\begin{array}{l}\text { Numerous reports from Newcastle } \\
\text { and Lake Macquarie Cities } \\
\text { Shops } \\
\text { Residential Dwellings }\end{array}$ & $\begin{array}{l}\text { Hunter Valley Region generally } \\
\text { Scone Motel } \\
\text { Liverpool } \\
\text { Childrens }\end{array}$ \\
\hline V & $\begin{array}{l}\text { General felt outside } \\
\text { Felt indoors by almost everyone } \\
\text { Sleepers awakened } \\
\text { Small unstable objects, upset or } \\
\text { displaced } \\
\text { Glassware and crockery broken } \\
\text { Hanging pictures move } \\
\text { Doors swing }\end{array}$ & - & $\begin{array}{l}\text { Numerous reports from Port } \\
\text { Stephens, Upper Hunter, Sydney } \\
\text { region. }\end{array}$ \\
\hline IV & $\begin{array}{l}\text { Generally noticed indoors } \\
\text { Not felt outside } \\
\text { Doors and windows rattle } \\
\text { Walls and frame of buildings creak } \\
\text { Glassware and crockery rattle } \\
\text { Vibration likened to passing of heavy } \\
\text { traffic or too heavy object striking } \\
\text { building }\end{array}$ & & $\begin{array}{l}\text { Numerous reports from all } \\
\text { districts. }\end{array}$ \\
\hline III & $\begin{array}{l}\text { Felt indoors } \\
\text { Vibration likened to passing of light } \\
\text { traffic }\end{array}$ & & $\begin{array}{l}\text { Numerous reports from all } \\
\text { districts } \\
\text { Canberra }\end{array}$ \\
\hline II & $\begin{array}{l}\text { Heard sound only } \\
\text { Few people indoors felt "something" }\end{array}$ & & $\begin{array}{l}\text { New England Tableland } \\
\text { Southern NSW }\end{array}$ \\
\hline I & $\begin{array}{l}\text { Felt in favourable circumstances such } \\
\text { as high rise buildings usually swaying } \\
\text { motion }\end{array}$ & & $\begin{array}{l}\text { Upper floors of highrise buildings } \\
\text { in Surfers Paradise and } \\
\text { Melbourne }\end{array}$ \\
\hline
\end{tabular}


There was both a selectivity and directionality to the damage pattern in Newcastle City, and to some extent in the outer suburbs and in Lake Macquarie City. There are many cases where, with adjacent buildings, one sustained significant damage while the other may not have been affected (albeit both usually suffered some damage to internal fittings and furniture). In some instances, consequential damage occurred wherein bricks or other building materials from a tall building crashed onto and through the roof of a smaller adjoining building (Figure 40). The pattern of damage exhibits a distinct directionality. For most cases of major damage where a wall collapsed, partially collapsed or became detached from the framework, it was the western wall which suffered (Figure 36). It is interesting to note that in the "highly subjective" reports of perceived direction of ground motion or building movement (from the Earthquake Questionnaires), a large proportion stated that movement was in an east-west direction.

\section{Isoseismal Maps}

The preliminary isoseismal map for the 1989 Newcastle earthquake is shown in Figure 55. On this map, assigned MM values for each particular locality (town or community) have been plotted and the contours drawn. Each MM value was an average for the particular locality, no account being taken of the urban (local) geological conditions therein. Detailed maps are currently in preparation. It is noted, however, that in many of the towns, greater effects were experienced on the soft sediments than on the hard rock with related reports of major damage, MM VI, extending to about $300 \mathrm{~km}$ from Newcastle. Examples of this damage were at Gladstone (near Kempsey) 250 $\mathrm{km}$ to the north, Cassilis $185 \mathrm{~km}$ to the northwest, Liverpool (Sydney) $130 \mathrm{~km}$ to the southwest and Wollongong $175 \mathrm{~km}$ to the south. Several reports of swaying motion being experienced in the upper floors of high-rise buildings (greater than 15 storeys), MM I, were received from Surfers Paradise, $600 \mathrm{~km}$ to the north, and Melbourne, $800 \mathrm{~km}$ to the southwest. The total area that experienced the effects of this earthquake was about $250,000 \mathrm{sq} \mathrm{km}$ which included an area of about $20,000 \mathrm{sq} \mathrm{km}$ within which major damage, MM VI or greater, was reported.
For the very near-field, within about $15 \mathrm{~km}$ of the published epicentre (Newcastle and Lake Macquarie Cities), the preliminary isoseismal map is shown in Figure 56. Average MM values for suburbs are plotted with indications of more serious damage at isolated sites shown in parenthesis.

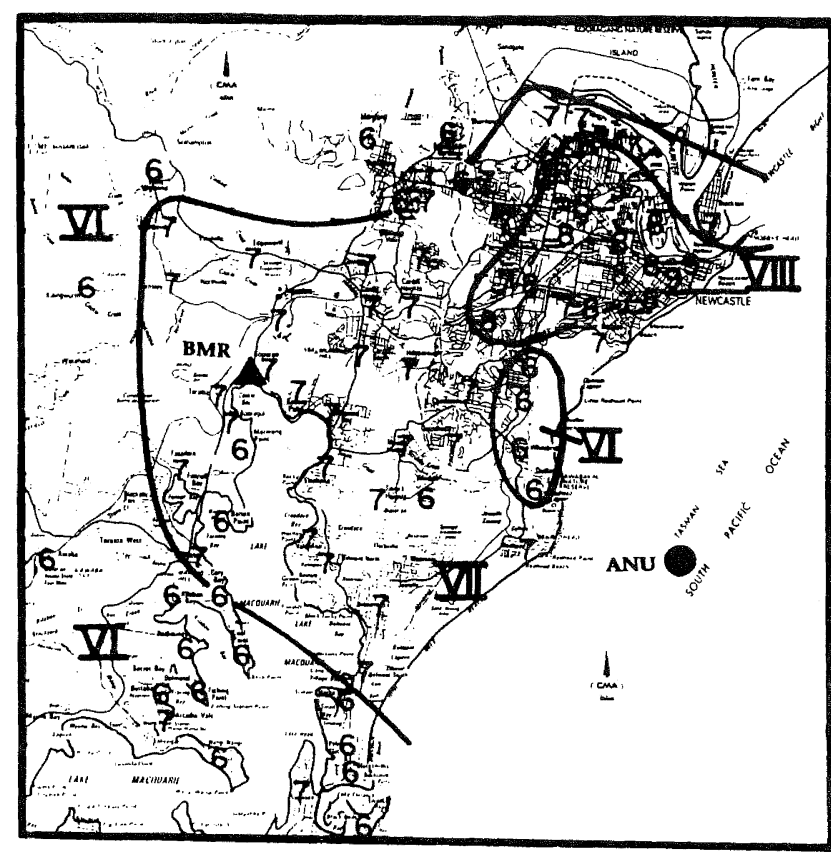

FIGURE $5 \dot{6}$

PRELIMINARY ISOSEISMAL MAP (ASSIGNED MM INTENSITY VALUES) FOR THE EPICENTRAL REGION (NEWCASTLE AND LAKE MACQUARIE CITIES) OF THE 1989 NEWCASTLE EARTHQUAKE

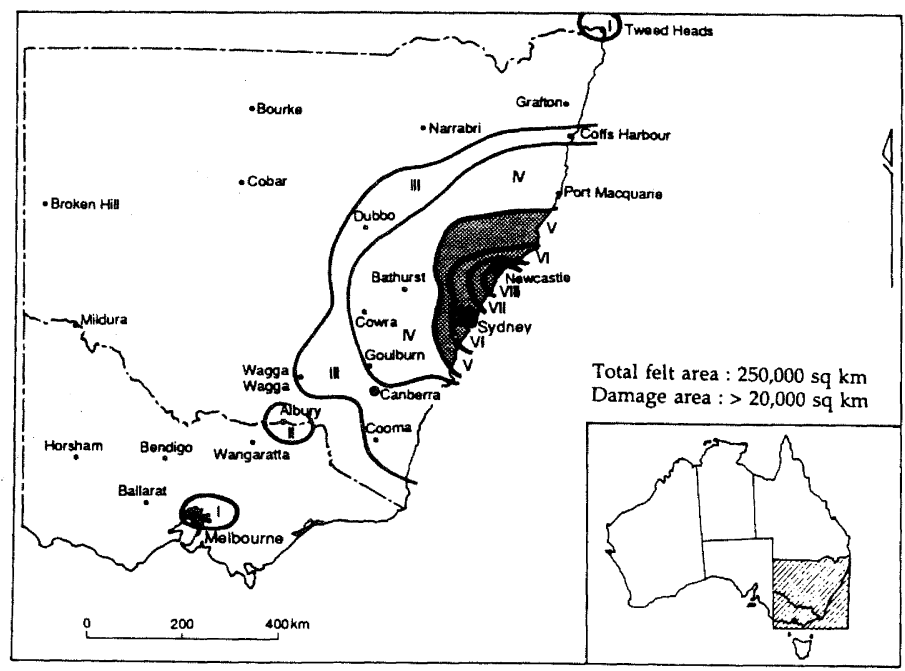

FIGURE 55 
The effects from the two subsequent events, the aftershock on December 29, 1989 and the other event on February 23, 1990 were experienced in the Newcastle-Lake Macquarie region as shown in the isoseismal maps of Figures 4 and 5, respectively. No reports of damage from either event was recorded, the most severe effects being the rattling of windows and household contents, an assigned intensity of MM IV. The total felt areas for these aftershocks were about $200 \mathrm{sq} \mathrm{km}$ and $130 \mathrm{sq} \mathrm{km}$, respectively.

\section{ATTENUATION OF SEISMIC ENERGY WITH DISTANCE}

The attenuation of seismic energy with distance, which interrelates ground motions and geological conditions (soft sediments and hard rock) is a most important engineering parameter for estimates of seismic risk, engineering design criteria and insurance considerations in forecasting future earthquake effects. Because of the lack of acceleration data, the attenuation is based on the assigned intensity values $\mathrm{MM}$ which are converted to peak ground acceleration (pga) through empirical relationships between intensity, pga, ML and epicentral distance. The method followed is that for Northeastern Australia [56], with such attenuation curves being developed for average site conditions, specific account not being taken of urban geology, particularly with regard to soft or wet sedimentary area.
The 1989 Newcastle earthquake attenuation curve is shown on Figure 57 using averaged intensity values (for all geological conditions) at various distances from the epicentre. By a comparison with the Northeastern Australia curves (shown in Figure 57) a lower level of attenuation out to several hundred kilometres from Newcastle is indicated. (Note that this comparison is considered reasonable with the currently available data, based on the assumption that the geological framework for these northern and central eastern parts of Australia is similar, namely, as parts of the accredited continental margin.) Calculated peak ground accelerations at four sites (based on three ground vibration records and a field estimate; Table 8) are also indicated.

FIGURE 57

ATTENUATIONRELATIONFOR THE

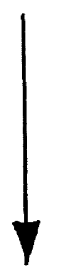

1989 NEWCASTLE EARTHQUAKE IN REFERENCE TO THE RELATIONS FOR NORTHEASTERN AUSTRALIA (FROM [56]). ASSIGNED MM INTENSITY VALUES FOR THE MOST SERIOUSLY DAMAGED AREAS WITHIN ABOUT $22 \mathrm{~km}$ OF THE EPICENTRE ARE SHOWN WITHIN THE DASHED BOX. CALCULATED PEAK GROUND ACCELERATIONS FOR FOUR GROUND MOTION ESTIMATES (TABLE 8) ARE SHOWN BY THE SOLID CIRCLES.

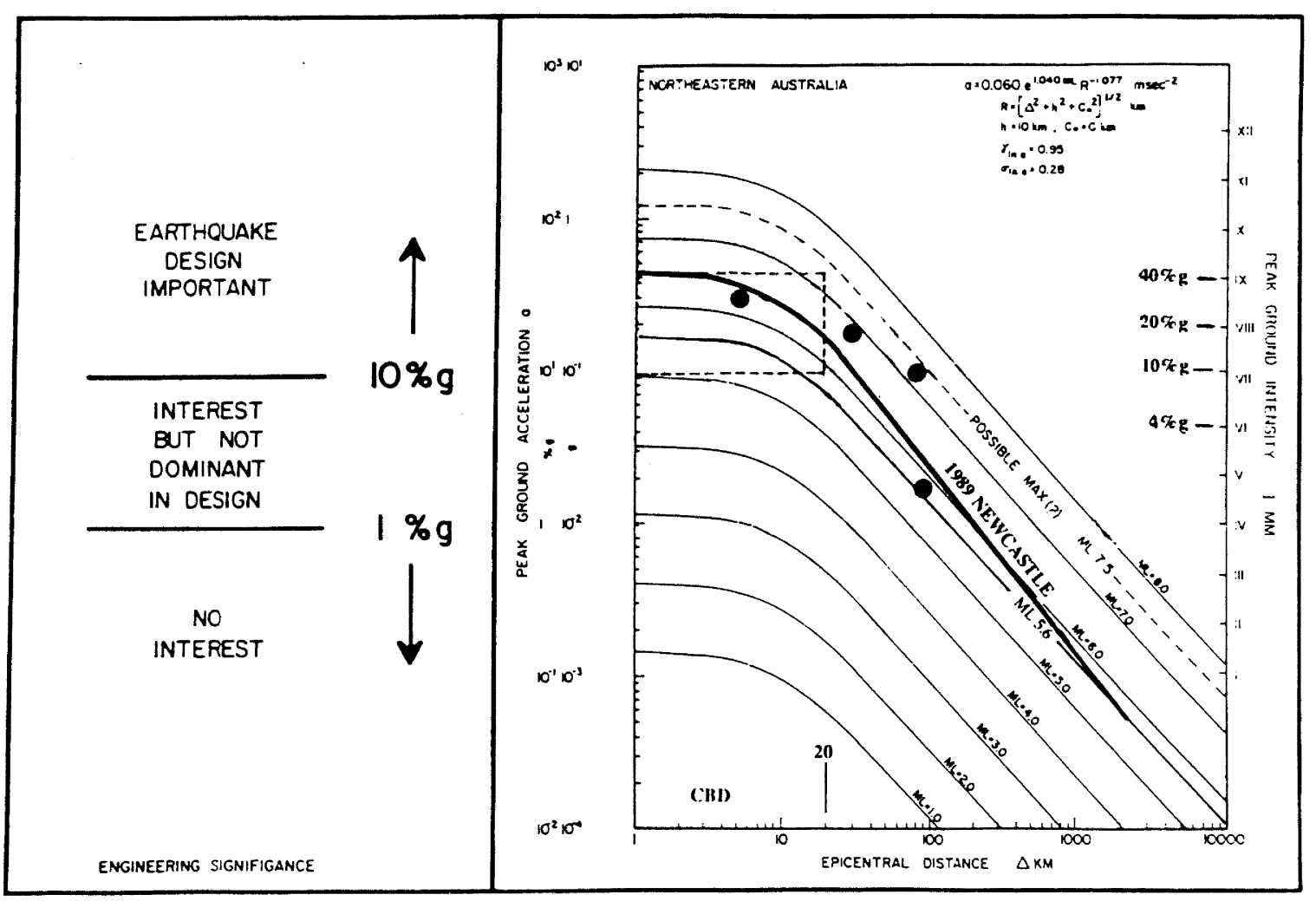




\section{GEOLOGICAL CONTROLS AND GEOTECHNICAL ISSUES}

\section{Geological Controls}

It was clearly evident in the early assessment of damage from the 1989 Newcastle earthquake that the total damage pattern was extremely dependent upon the geology of the area concerned [14]. Specifically, the zone of maximum damage coincides very closely to the areas of Holocene sediments (Figure 58).

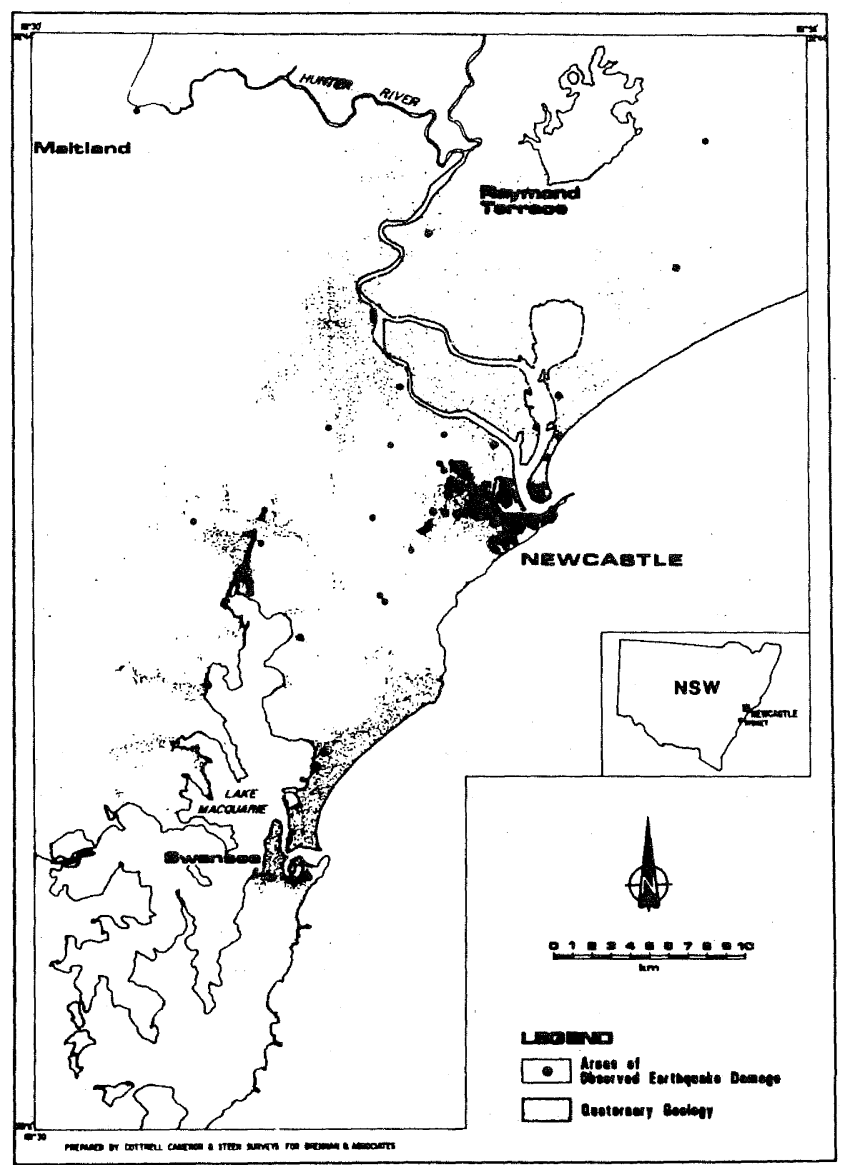

FIGURE 58

MAJOR BUILDING DAMAGE
REPORTED IN THE CITY OF
NEWCASTLE AND SURROUNDING
REGIONS IN RELATION TO
HOLOCENE SEDIMENTARY AREAS
(AFTER [14])

This geological relationship to the most serious damage in the Newcastle City area (MM VII - IX) became apparent during the initial analyses of the damage reports [8]. To the south around Lake Macquarie (Lake Macquarie City precincts), such geological controls on the damage were observed in many locations: in the Belmont business district with buildings on low lying sand and wind blown stabilised sand dunes; in private dwellings in Swansea of the same sandy terrain; at Boolaroo and Speers Point on Holocene sediments from Cockle Creek; at Teralba and other centres on the western shores of Lake Macquarie with buildings on recent infill of Lake Macquarie. Further south, evidence was seen at Budgewoi on Holocene marine sediments and in Sydney on coastal sands in the northern beachside suburbs and on alluvial river flats at Liverpool (on the banks of the Georges River). To the west, most of the damage was on river alluviums as at Maitland (Hunter River) and Cessnock (Black Creek). In the northern sector at considerable distance from Newcastle, the damage at Scone (recent alluvials of Middle Brook) and Gladstone (near Kempsey, river flats of the Macleay River) was related to similar conditions.

There are surprisingly few exceptions to this condition even with the complete damage report data set now available. Some areas with recorded damage which do not follow this condition include those located on basement rock the immediate epicentral area which were subjected to the most severe ground shaking; some parts of Cessnock (including the hospital); and the Norah Head Lighthouse.

The impact of this observation is a most serious consideration with the occurrence of future earthquakes in all areas of urban Australia, and indeed in most countries of the world, where population, industry and tourism are located in coastal areas usually on rivers and with ports located at river mouths. Even the insurance industry has recognized the increase in potential loss (from all natural disasters including earthquakes) due to the current trend of population movement to the coastal areas [57]. Unfortunately the relevance of urban geology and the resultant earthquake effects have, for some years, been overlooked and indeed diminished.

The geological factors influencing the severity of earthquake damage can be broadly classified into:

(a) seismological : epicentre, magnitude, source characteristics, frequency and duration of shaking, epicentral distance; and

(b) site specific geology : hard rock, recent alluvial cover (marine or fluvial), depth of alluvium over hard rock, shape of interface between hard rock and alluvium.

This has recently been manifested in "geotechnical" terms whereby the salient parameters are surface geological (sediments) description, shear wave velocity and soil factors [58].

In Newcastle, in common with most of the east coast of Australia and many other parts of the world, a significant portion of the City is built on sedimentary cover that has been put in place since the closing of the Pleistocene ice age, which started some 110,000 years ago and is still closing (almost all glaciers in the world are still retreating, with a few notable exceptions). Thus, recent sediment in Newcastle is a combination of marine sands that are basically well sorted and classified and fluvial sand, silts, and muds that are poorly sorted. Mixed into this are layers of organic rich material of a peat-type composition and in some places some poorly indurated sand layers that frequently are mistaken for "bed rock sandstones" (Figure 59). This complex mass of sediment is largely saturated to within a metre of surface and frequently the surface layer is windblown dune sand that has been emplaced to cover an otherwise swampy wetsurface. In other locations, power station ash and slag from the Newcastle Steel Works has been used as the topping layer.

This material has low shear wave velocities in the range from about $80 \mathrm{~m} / \mathrm{sec}$ to $200 \mathrm{~m} / \mathrm{sec}$. (There is evidence that some organic rich muds and silts may be as low as $60 \mathrm{~m} / \mathrm{sec}$ ). The depth of this post-Pleistocene material can be of the order of 80 metres since this is the rise in sea level that has taken place in the region. From the scattered and totally insufficient bore-hole data available, it is indicated that $10-40$ metres thickness of Holocene sediment is common under Newcastle. The thickness of that sedimentary pile has two principal effects: (a) it controls 


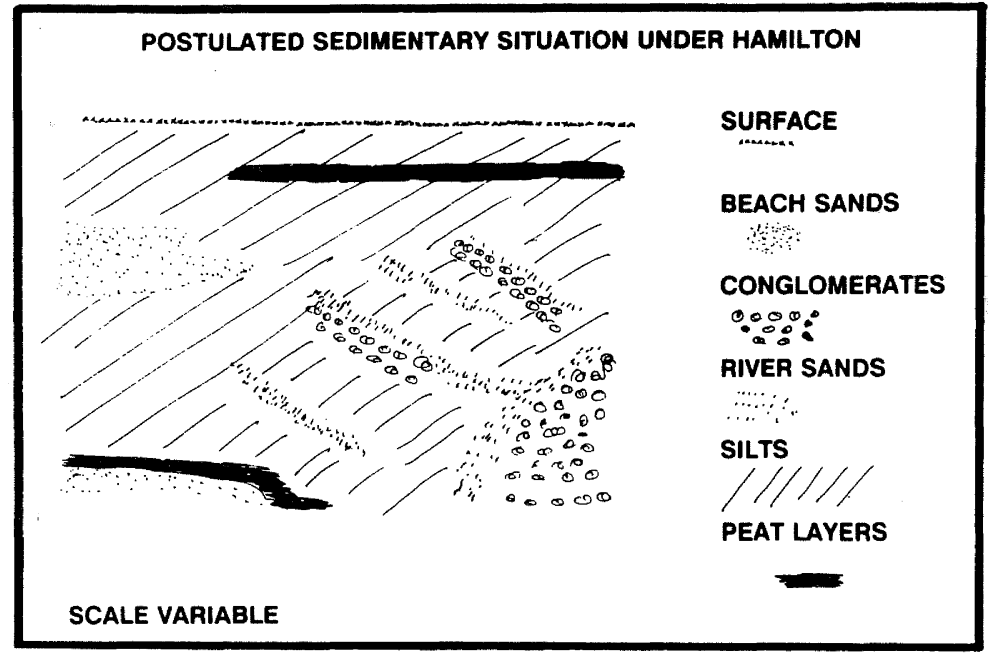

FIGURE 59

ILLUSTRATION OF COMPLEXITY OF RECENT ALLUVIAL COVER (HOLOCENE SEDIMENTATION) IN THE CITY OF NEWCASTLE REGION (FOR EXAMPLE : CBD AND HAMILTON). NOTE THAT THE SCALE CAN BE HIGHLY VARIABLE BOTH VERTICALLY FROM A FEW METRES TO SEVERAL TENS OF METRES AND HORIZONTALLY FROM A FEW METRES TO KILOMETRES

the frequency of resonance of the sedimentary pile in conjunction with shear wave velocity; (b) the thicker the sedimentary pile, the more opportunities exist for liquefaction of a layer (noting that the layer may be of significant thickness or quite minor in the total stratigraphy of the sedimentary pile which may occur at a specific site).

A factor of site specific geology that appears to be totally overlooked by most is the shape of the sub-surface layer and the impact that the slope of the sub-surface layer can have on lateral movement of the surface layers of wet recent sediments. Even if liquefaction, as defined by the geotechnical engineers, fails to occur, the interface between hard rock and the surface layers of alluvium is well lubricated with water and will allow movement sideways on relatively low angles. The sub-surface topography in Newcastle will reflect to some extent the current hills around the alluvial areas and hence there will be quite steep slopes under the alluvial allowing lateral creeps. Only small amounts of creep under a building with poor footings would cause significant damage.
An area where it would be entirely reasonable to assume that some lateral creep has taken place is in the Scott Street - Hunter Street area of the Newcastle CBD. The steep slopes of Bull, Newcomen and Watt Streets CBD will have continued for some distance under the now existing alluvial cover. With the amplification that occurred in this area, it is highly likely that liquefaction of the units of silty material would have occurred allowing sideways (or lateral) movement to have taken place. The total movement may not have been great but, with buildings such as Carrington Chambers (Watt Street, CBD) where the floors and the walls, it was reported, were not tied together and minimal footings only existed, major damage would then result from small movements. This is illustrated in Figure 60.

Several other situations of sub-surface slope are also recognised and are important. These include the effects of a buried ridge or hill (Figure 61), which is strongly suggested as the type of mechanism responsible for the ground movements in the Beaumont Street, Hamilton, area, and/or of a buried valley (Figure 62), which may account for the movements in areas like Carrington.

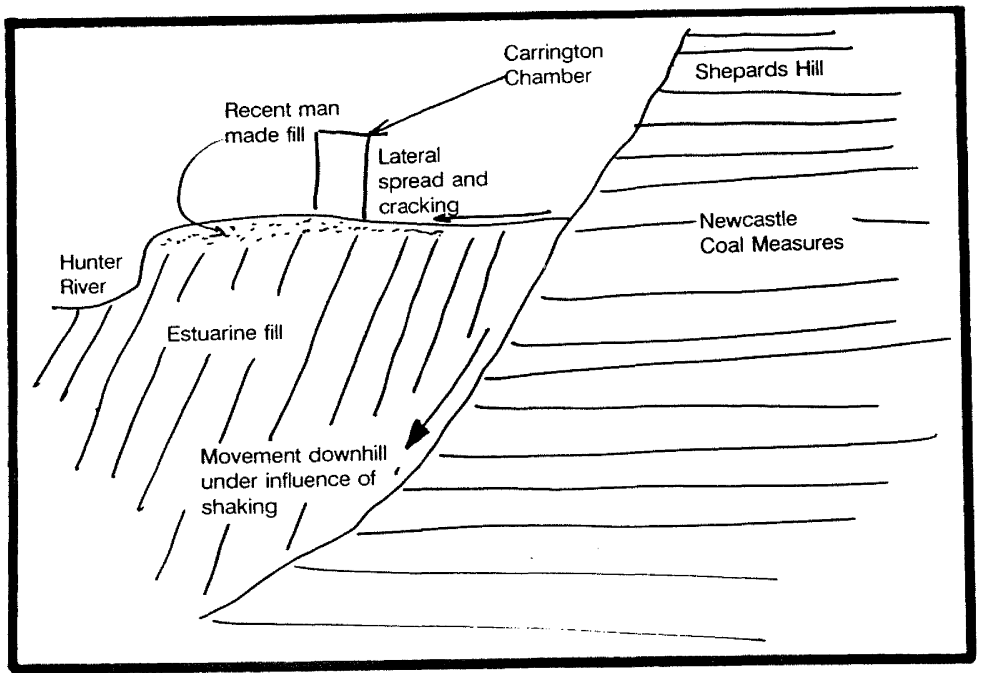

\author{
FIGURE 60 \\ ILLUSTRATION SHOWING THE \\ SHAPE OF THE SUB-SURFACE \\ TOPOGRAPHY IN THE NEWCASTLE \\ CBD AREA, FOR EXAMPLE, AND \\ THE RESULTANT EFFECTS ON \\ GROUND MOVEMENTS
}


FIGURE 61

ILLUSTRATION SHOWING POSSIBLE SURFACE GROUND MOVEMENTS IN RELATION TO A BURIED RIDGE OR HILL
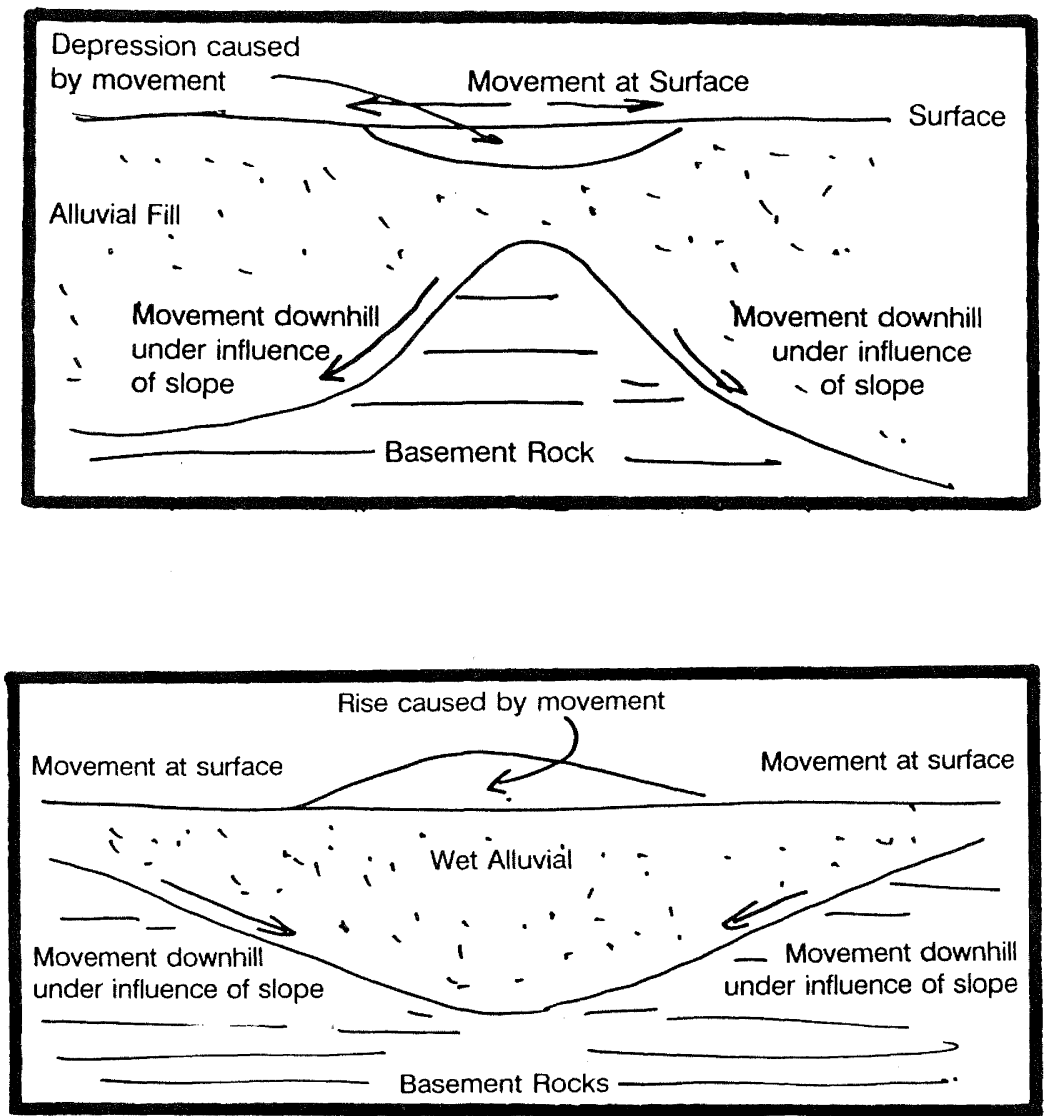

FIGURE 62

ILLUSTRATION SHOWING POSSIBLE SURFACE GROUND MOVEMENTS IN RELATION TO A BURIED VALLEY
It should be noted, however, that totally insufficient sub-surface data exists at Newcastle and indeed any area of estuarine or marine fill in Australia. In Newcastle, a sub-surface topography map has been produced by Coffey Partners International Pty. Ltd., Consulting Geotechnical Engineers, (in [9]) which is based on the best available data. However, at least a significant increase in coverage (and thus data) is needed for the map to be really meaningful. In this regard, it is difficult to assess the meaning of the surface levelling data presented in [59] since there is no corresponding sub-surface topography information. This levelling survey covered a wide area of Newcastle, Lake Macquarie and Port Stephens Shires (within about $50 \mathrm{~km}$ of the Newcastle CBD; Map 2 in [59]). The results show that surface ground movements since the last survey, prior to the Newcastle earthquake, ranged from $60 \mathrm{~mm}$ downwards to $17 \mathrm{~mm}$ upwards in Newcastle City area. Similar range of results is shown in the maps for the whole area survey and from Raymond Terrace to Doyalson (Diagrams 4-6 in [59]). While the paper discusses many non-earthquake related reasons for movement, it is clear from the foregoing discussion that there was amplification sufficient to cause liquefaction, and that there is sufficient sub-surface slope under the wet sediments in Newcastle to have caused lateral creep such that elevation changes occurred.

The significance of geological controls in understanding amplification and liquefaction is the major issue to be addressed both to explain the damage patterns of the 1989 Newcastle earthquake and to prepare for potential damage in future earthquakes.

\section{Amplification}

Some approximate measure of (relative) amplification can be ascertained from Figure 57 by comparing the attenuation curve based on the ML 5.6 Northeastern Australia relation with that for the 1989 Newcastle data. The indications are of amplification factors of 2-4, with isolated specific sites up to 4-8, in the near-field. These values compare favourably with those derived from intensity relationships given in [9], are slightly lower than those calculated from geotechnical considerations, from 4-10 for specific damaged sites, as given by Coffey Partners International Pty Ltd in [9], but do not agree with those given by V.Chandrasekaran (CSIRO) of about $14+2$ in [8]. The scatter in such non-instrumentally based information is evident (as also shown in [9]).

Estimates based on four strong ground motion calculations are given in Table 8, again showing some scatter.

As well as the theoretical geotechnical calculations, the importance of the sub-surface material at specific sites of damage (the geological controls) must be recognized as a vital element in any consideration of amplification. Consider the following two examples: 
TABLE 8: CALCULATED PEAK GROUND MOTION ACCELERATIONS AND ESTIMATES OF AMPLIFICATION FACTORS

\begin{tabular}{|c|c|c|c|c|c|c|}
\hline SITE & $\begin{array}{l}\text { EPICENTRA } \\
\text { LISTANCE } \\
\quad(\mathrm{km})\end{array}$ & $\begin{array}{c}\text { DATA } \\
\text { SOURCE }\end{array}$ & $\begin{array}{c}\text { FREQ. } \\
(\mathrm{Hz})\end{array}$ & $\begin{array}{c}\text { pga } \\
\left(\mathrm{mm} / \mathrm{sec}^{-2}\right)\end{array}$ & $\begin{array}{l}\text { CAL- } \\
\text { CULATED } \\
\text { pga }(\% g)\end{array}$ & $\begin{array}{l}\text { AMPLIFI- } \\
\text { CATION } \\
\text { FROM } \\
\text { (FIG.57) }\end{array}$ \\
\hline $\begin{array}{l}\text { TAFE College } \\
\text { Tighes Hill }\end{array}$ & 5 & $\begin{array}{l}\text { Field calculation } \\
\text { based on building } \\
\text { design }^{(\star)}\end{array}$ & - & - & 30 & $2-3$ \\
\hline $\begin{array}{l}\text { Ellalong } \\
\text { Coal Mine }\end{array}$ & 30 & $\begin{array}{l}\text { Vibration record } \\
\text { velocity output }\end{array}$ & 6.5 & 4.43 & 18 & 5 \\
\hline $\begin{array}{l}\text { Muswellbrook } \\
\text { Coal Mine }\end{array}$ & 80 & $\begin{array}{l}\text { Vibration record } \\
\text { digital readout of } \\
\text { peak value }\end{array}$ & 5.0 & 3.20 & 10 & 6 \\
\hline $\begin{array}{l}\text { Drayton } \\
\text { Coal Mine }\end{array}$ & 90 & $\begin{array}{l}\text { Vibration record } \\
\text { digital readout of } \\
\text { peak value } \\
\end{array}$ & 1.5 & 1.56 & 1.5 & 1 \\
\hline \multicolumn{7}{|c|}{$\begin{array}{l}\text { (a) J.Fenwick, pers.comm., } 1990 \\
\text { (b) Record courtesy of Newcastle "Herald" } \\
\text { (c) Data courtesy of J.Bailey, Costain Australia Ltd. }\end{array}$} \\
\hline
\end{tabular}

For the Newcastle earthquake, it is well documented that major and significant damage was suffered at the Newcastle TAFE College, Tighes Hill (Figure 63). Yet, only about 150 metres away, in the Tighes Hill shopping centre, the Varley Building (Figure 64) suffered no damage, except the dislodging of three small (approx $50 \mathrm{~mm} \times 90 \mathrm{~mm}$ ) tiles from the front exterior wall (Figure 65). The TAFE College is built on about 20 metres of creek fill alluvium flats underlain by the Newcastle Coal Measures, while the Varley Building is on Permian Tighes Hill Group sediments of Newcastle Coal Measures. There is almost an infinite scale of damage between the two sites, both at virtually the same distance from the epicentre. It is also interesting to note that the Varley Building and the Darling Building at the TAFE (which sustained most severe damage) are of similar construction and age, both being built in the mid-1930's of largely unreinforced brick. This vast difference in damage must be caused by the effect of the local site geological conditions. Thus, amplification at the TAFE College on the recent alluvial cover, probably a factor of 6 or more, must have occurred.

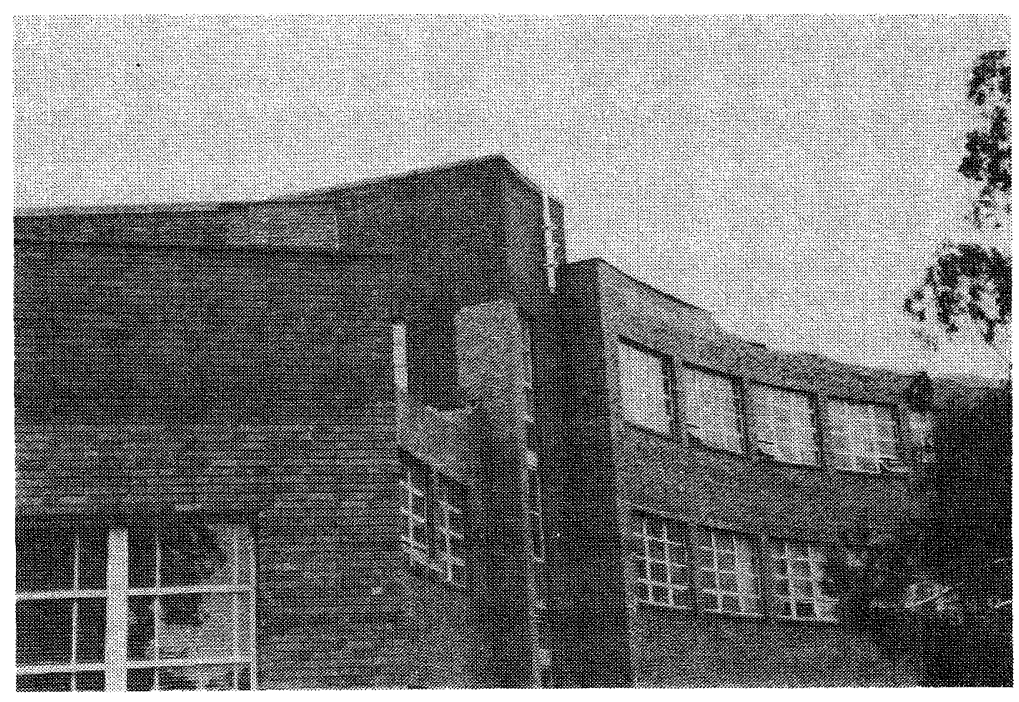

FIGURE 63

NEWCASTLE TAFE COLLEGE, TIGHES HILL SHOWING SEVERE PARAPET DAMAGE TO THE CLEGG BUILDING

(4.1.90; C.R. FEATHERSTONE) 


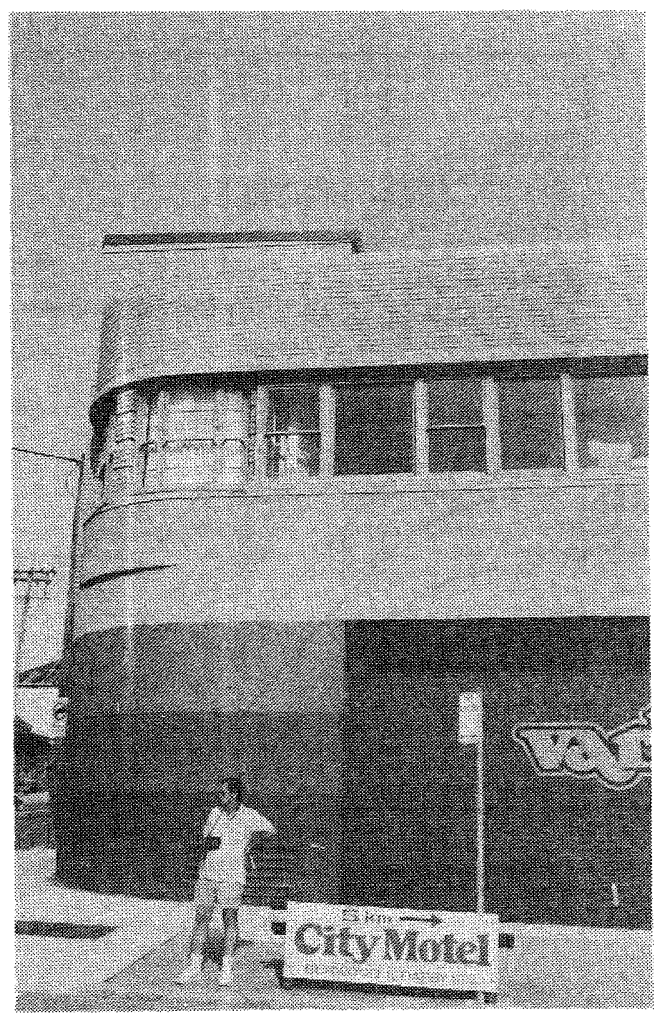

FIGURE 64

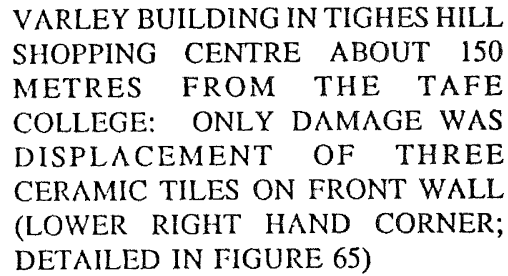

SHOPPING CENTRE ABOUT 150

METRES FROM THE TAFE

COLLEGE: ONLY DAMAGE WAS

DISPLACEMENT OF THREE

CERAMIC TILES ON FRONT WALL

DETAILED IN FIGURE 65)

(19.1.90; E.BRENNAN)
On February 22, 1991, an ML 2.0 earthquake occurred at Fingal, near the Gold Coast on the Queensland - New South Wales border. Seismologists and engineers would not even remotely consider significant ground motion effects for such a small earthquake. However, as shown in the study of this earthquake [60], a large part of the Gold Coast-Tweed Coast region experienced effects with assigned intensities of MM IV with several substantial areas of minor damage MM V-VI. The affected area is totally built on a mixture of marine and fluvial sediments of Holocene age resting on hard metamorphic rocks of late Devonian-Early Carboniferous age Neranleigh-Fernvale Beds and so again invokes significant amplification of the seismic waves at the surface from the alluvial cover.

The Newcastle and Fingal experiences clearly identify the necessity to understand the enormous importance of the nature of the rocks on which the recent sedimentary pile has been built, such as the bedrock at Newcastle or the near crystalline basement at Fingal. It appears that it is this critical factor of the nature of the rocks under the recent alluvium that really distinguishes continental and plate margin earthquakes. The "hardness" or state of "lithification", and hence the shear wave velocity of those rocks, controls, along with the shear wave velocity of the recent sedimentary pile, the first component of amplification - an amplification which MUST exist. In Newcastle, there have been many arguments about amplification and its existence, with many people saying "since we had no instrumental records to prove that amplification took place, we can only say it may have been a factor".

However, the principle of conservation of energy dictates that amplification takes place in all situations of recent alluvial cover. Consider the well-known Gutenberg - Richter expression for the energy-amplitude relationship for earthquake waves [61]:

$$
E=y \cdot a^{2} \cdot v_{s},
$$

where $E=$ Energy

$\mathrm{y}=\mathrm{a}$ factor applicable to a given earthquake

$\mathrm{a}=$ amplitude

$v_{1}=$ shear wave velocity.
FIGURE 65

CLOSE-UP OF THE THREE CERAMIC TILES DISLODGED FROM THE VARLEY BUILDING (FIGURE 64)

(19.1.90; E.BRENNAN)

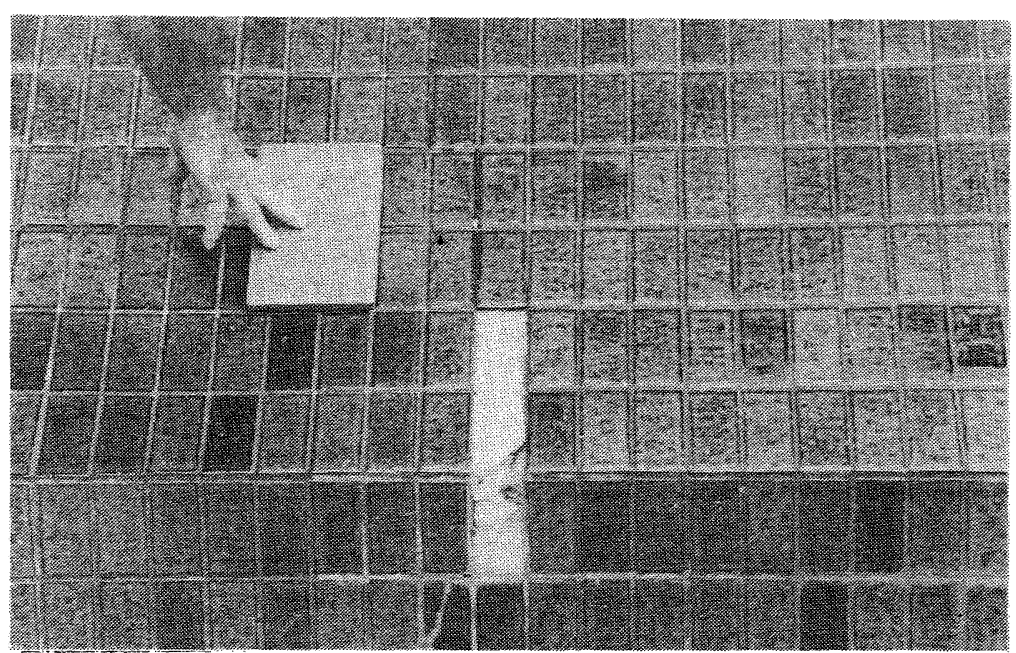


Then, the amplification, $\mathrm{K}$, is given by:

$$
\mathrm{K}=\frac{\mathrm{a}_{1}}{\mathrm{a}_{2}}=\left[\frac{\mathrm{v}_{\mathrm{s} 2}}{\mathrm{v}_{\mathrm{s} 1}}\right]^{1 / 2}
$$

where subscripts 1 and 2 refer to the upper and lower layers, respectively.

This amplification is independent of resonance. Since the pre-Holocene material can have shear wave velocities as high as $4500 \mathrm{~m} / \mathrm{sec}$ and the Holocene alluvium shear wave velocities as low as $60 \mathrm{~m} / \mathrm{sec}, \mathrm{K}$ can be as high as 8.7 .

The same expression for amplification has been derived by considering wave front geometry [62] . Based on instrumental observations in China from seismic waves recorded down holes and at the surface, resulting amplifications (at the surface) of the same order as above were obtained. It is also evident that in a situation such as Newcastle where very low shear wave velocity material overlies harder older rocks (Permian sandstones,conglomerates etc), the amplification factor will be significantly higher than if the underlying rocks are soft, (Cretaceous sediments), as in the case in many plate margin areas ([62]; comparisons between China, USA and Japan).

\section{Liquefaction}

Liquefaction is defined as sediment movement where the sediment flows as a liquid. This phenomenum is one of the significant causes of damage from earthquakes to engineered structures in saturated sedimentary deposits. Although no direct evidence of liquefaction on the ground surface was observed in the 1989 Newcastle earthquake, a simplistic approach based on the northeastern Australia attenuation curves and the assigned intensities to the Newcastle damage reports, suggests that liquefaction at depth (within the surface sediments) may have been possible in the near-field (up to $50 \mathrm{~km}$ from the epicentre) which includes Newcastle and Lake Macquarie Cities and the Maitland areas [63].

Figure 66 shows the situation for the Newcastle-Lake Macquarie area $(0-20 \mathrm{~km})$ for MM VII - IX and Maitland area $(20-50$ $\mathrm{km}$ ) for MM VI - VII. This is consistent with the statement by Coffey Partners International Pty. Ltd. (in [9]) who tentatively concluded that liquefaction could have contributed to the damage of structures at specific sites in the Newcastle City area. Such a scenario can also be considered for the far-field taking the examples of damage in Scone and Cassilis, at distances of $100-200 \mathrm{~km}$ from Newcastle for which [63] invokes liquefaction in the saturated sediments underlying the damaged structures associated with a ground amplification factor of 2 to 4 (Figure 66).

Such liquefaction potential has been evident for earthquakes in other parts of the world. For example, the data presented regarding the 1727 Newburyport (USA) earthquake (ML 5.0) [64], indicates that the lower limit of magnitude that causes significant liquefaction in a continental situation than previously considered, and much lower than in a plate margin situation. (Indeed logic shows that this should be so, because there is a higher amplification in continental situations.) Thus, situations of potential soil creep due to sub-surface topography are potentially much more dangerous at lower magnitude earthquakes in the continental situation compared with the plate margin situation.

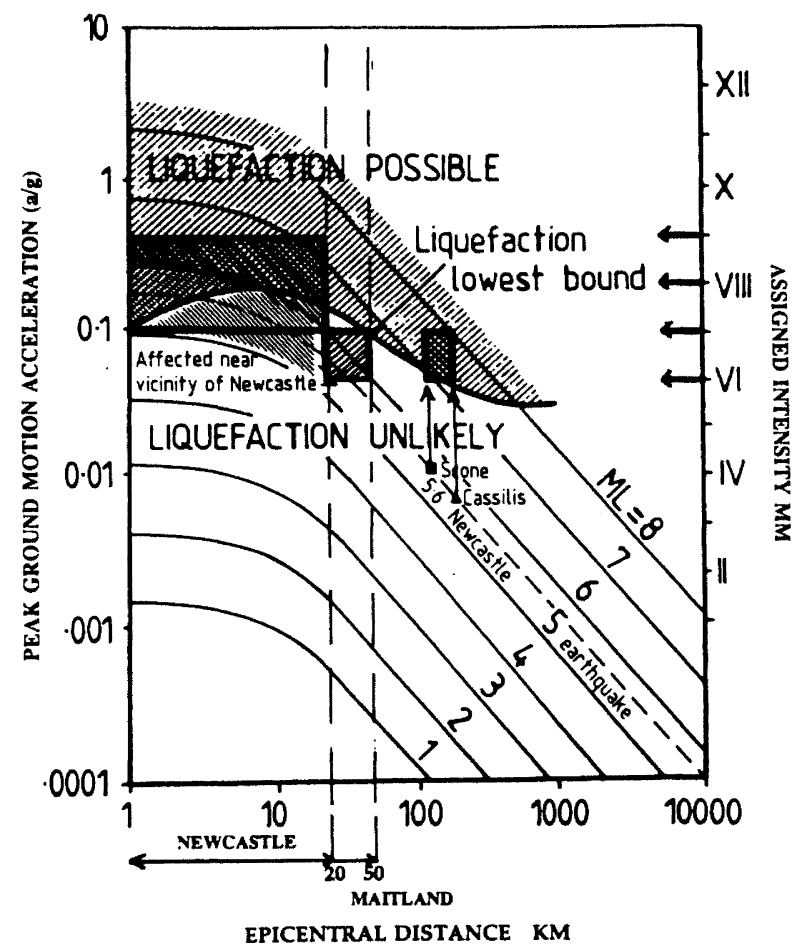

FIGURE 66

\section{ENGINEERING CONSIDERATIONS}

\section{Damage to Commercial Buildings}

With the exception of the Newcastle Workers Club (Figure 7) and The Junction Motor Lodge (Figure 67), the majority of structural failure and damage has occurred in what can be termed "old structures". There has been little evidence of overall building collapse. In general, it has been elements within the building that has caused excessive damage to the building structure itself and to the public. The building stock in Newcastle is generally old (i.e. pre-1950's), with few major developments having taken place in the past 20-30 years. The main area for major commercial development has been Hunter Street. Of the buildings constructed to date, approximately 20 are greater than 6 storeys in height whilst approximately $40 \%$ of the buildings are over 2 storeys in height. The remainder are single and two storeys which make up approximately $50-60 \%$ of the building stock in the CBD of Newcastle [65]. The extent of damage can be divided into two classifications, pre-1950 (older building) and post-1950 (newer) construction. 
FIGURE 67

THE JUNCTION MOTOR LODGE, CORLETTE AND KENRICK STREETS, THE JUNCTION: MAJOR STR UCTURAL DA M A GE NECESSITATING DEMOLITION, THE RESULT OF SOFT STOREY FAILURE WITH ASYMMETRICAL DESIGN LAYOUT

(28.12.89; I.S. PEDERSEN)

\section{Pre-1950 (or older) buildings}

Typically the buildings over two storey are framed structures, with steel encased concrete, concrete reinforced or timber columns and floors, fibre cement or metal type roofs and stone or masonry facades. The extent of damage to the structural frames (columns, beams, slabs) has been generally negligible. The masonry perimeter walls and internal stair and lift core walls have suffered cracking. In many cases, the perimeter walls were load-bearing, supporting the floor and roof structure. The slenderness ratios are generally higher than current standards. Most of these buildings had unreinforced and unbraced masonry parapets above roof level with freestanding heights up to 2.0 metres. Many of these buildings once had awnings supported on timber or steel posts at the kerb line, but have been modified so that they are hung from above with steel rods fixed into the masonry with a single bolt. In some cases, the damage to other parts of the building (for example: internal core walls) has been so extensive that the whole of the building has had to be demolished.

The single and two storey walk-up unreinforced masonry commercial buildings constructed pre-1950 have sustained the most damage. In nearly all cases the roof is timber framed supported on masonry piers with little or no ties (anchorage) to the masonry. The walls have moved laterally during the earthquake at a rate different to the roof, and since either the wall above-ground or the first floor level some 3-5 m high not being tied to the roof structure, the walls have fallen out or moved sufficiently to cause the roof to collapse. In some cases the boundary wall masonry has fallen onto the roof of the adjacent property or onto the street awning, causing more damage. Lead flashings embedded into the masonry skins are also a concern in relation to sound engineering design for lateral forces. Many of these older buildings have been modified over the years, by such works as the installation of new steel beams above ground floor ceiling level to support the masonry over, so that glass shop windows at street level could be installed. This has further exacerbated the problem.

The parapets and unrestrained masonry walls in these types of buildings are of great concern, not only in Newcastle, but throughout Australia. For future safety, it is imperative that all untied masonry walls be mechanically tied to the structure. For example, parapets should be lowered or properly braced back to the roof structure. Three people lost their lives in Beaumont Street, Hamilton, a suburb of Newcastle, due to the collapse of parapets and awnings onto the street below.
It is also necessary to maintain any new braces, when installed, by regular painting, corrosive reduction and the like. Such maintenance on our older buildings has not been taking place, especially when it is known that the corrosive nature of the saltwater sea spray will reduce the capacity of the mortars used. In nearly all these pre-1950 buildings, the masonry has been constructed using lime-type mortars and pointing. Little or no maintenance has been undertaken, to the point where this building stock needs major refurbishment or replacement, particularly if and where reinforcement for basic earthquake resistance is required.

\section{Post-1950 (newer) buildings}

Commercial buildings over two storeys and post 1950's are generally steel or concrete framed structures, with infill masonry wall panels of say, $5.0 \mathrm{~m}$ wide $\times 3.0 \mathrm{~m}$ high, fixed between the structural frame. The front facades are typically glass, lightweight curtain wall, precast concrete or masonry and glass. The most recent building constructed, the nine storey Australian Taxation Office is a concrete framed, flat slab structure with masonry/veneer perimeter walls and concrete columns, concrete lift and stair core walls and lightweight metal stud walls to the plant rooms and toilets on each floor. The damage to this structure was very minor with hairline cracking internally to the plasterboard walls around the building perimeter and core areas. At the roof lift motor room, masonry infill walls between the steel frames structure cracked up to $1.5 \mathrm{~mm}$ width in about four locations. Another example is the recently built 6 storey MMI Building, with steel frames with concrete floors. It suffered hairline cracking to some walls. The masonry parapet, $1.0 \mathrm{~m}$ high above the roof level cracked at the western and northern end and has since been removed. In general, the post-1950 buildings have had little damage structurally. The architectural facades, finishes and masonry infill panels have suffered in these buildings, but damage has been of a minor nature.

Future requirements for slenderness ratios in masonry panels needs to be reconsidered in light of the wind and earthquake loadings, which can be applied, and the quality of the masonry and mortar strengths in construction being lower than anticipated. As the design of building facades is now becoming a structural engineering, rather than an architectural, element, these features have to be considered for their structural integrity and strength and not for their architectural features. Indeed, one matter that an earthquake or,any other type of overload situation 
will show is deficiencies in design or construction. Cases where corroded reinforcement and improperly placed reinforcement have been exposed by the delamination of concrete cover to the reinforcement show the inadequacy of the construction when earthquake forces are imposed on the building.

\section{Cause of building failure at the Newcastle Worker's Club}

Approximately two hours after the earthquake, the emergency services contacted one of the authors (ISP) and requested his attendance at the Newcastle Worker's Club building site to provide structural engineering advice to the rescue services in searching for and rescuing trapped people inside the collapsed building. Nine people lost their lives in this building.

The failure mechanism of the building was the subject of work undertaken by Consulting Engineers Rankine \& Hill for the subsequent Coroner's Earthquake Inquest [66]. It should be noted that it is impossible to categorically define the exact cause of failure but in the opinion of one of the authors (ISP), the probable cause of failure was falling non-load bearing masonry due to its instability under the earthquake loading imposed.

This building was formed by a conglomerate of buildings and "add-ons" to the pre-1960 original building and a major extension constructed in 1971. This 1971 major extension, was tied to the older building on one side only, and represented about $50 \%$ of the overall building construction on the site. The 1971 building was that which collapsed and consisted of a 4-storey building plus carpark basement, of reinforced concrete frame and flat plated concrete floors with unreinforced nonload-bearing masonry infill panels, or glass along its perimeter walls.

The western upper floor masonry infill walls fell both inwards and outwards. Those bricks falling inwards fell onto a balcony supported from the roof which caused the roof to collapse onto the second floor which with the additional load concertinaed onto the other floors with the columns punching through the floors as they fell to the ground floor and basement.

\section{Damage to Domestic Buildings}

Damage to houses has been extensive. The most severe damage was in the inner areas of the City where the older (pre-1950) age of the building stock and the foundation material (alluvial deposits) were the prime causes. The damage ranged from minor cracking to complete loss of structural integrity resulting in the need for evacuation and demolition in many instances. In the older areas of Newcastle, most housing is either of traditional cavity masonry or of timber frame construction. The earthquake damage revealed many houses in various degrees of deterioration, with corroded wall ties, poor mortar joints, etc. Masonry chimneys were a major hazard for older houses (chimneys are uncommon in the newer dwellings). In many areas, horizontal earthquake forces caused chimneys to dislodge at roof level, usually in the region of the flashing tray, which is a discontinuity in the structural integrity of the building. In some cases, the chimneys overturned, falling to the ground or through the roof. Most, however, slid or rotated at their base/flashing tray and had to be either dismantled or repaired. In the period immediately following the earthquake, damaged chimneys were a major cause of concern because of the possibility of aftershocks and the safety of people below.
Most of the newer suburbs (since 1960) are located on or beyond the ridges surrounding the central alluvial basin of inner Newcastle. Houses in these areas are mostly of timber or masonry veneer construction. Timber houses were the least affected by the earthquake, followed by those of masonry veneer construction and then cavity masonry construction, which were the worst affected.

Timber houses in Newcastle are typically constructed of timber stud framing, clad with weatherboards, lined with some form of plaster boarding and with a tiled or metal roof. Buildings of this type performed well in the earthquake because of their flexibility and low mass. Even though substantial lateral movements were observed, little damage was sustained. Some minor cracking to internal plaster finishes was common, particularly at cornices. The main cause of damage that did occur was relative movement of the flexible timber structure in relation to other more rigid elements of the building, such as masonry chimneys and fireplaces and masonry verandahs.Movement of the complete structure in relation to its foundations was also relatively common. This was sometimes the result of sliding on the top of piers and foundation walls, or the result of tilting or settlement of foundation piers, especially for houses with timber floors built above the ground. Although in some cases these lateral movements were substantial, (in order of $20-30 \mathrm{~mm}$ ), the structural integrity of the building was rarely threatened.

Masonry veneer houses also performed reasonably well due to the influence of the loadbearing timber frame. Because most dwellings of this type were relatively new, there was little evidence of wall tie corrosion. Transverse panel failure of the masonry veneer outer skin was therefore rare except in the case of some gable ends with inadequate tying to the roof framing. However, there were cases of displaced or tilted outer skins where movement had occurred between the veneer and its supporting timber frame, with accompanying cracking at corners and returns. There was also evidence of minor damage to tiled roof systems which displaced under the action of the horizontal forces. One area of concern has been the insufficient number of wall ties (as per Building Code requirements) which has allowed damage to occur to the masonry skin. The problem here has been lack of adherence to construction standards by the builders.

The older type cavity masonry houses (many at least 60 years old) were by far the most badly damaged in the earthquake. The typical form of construction consists of external cavity masonry walls (some with a load-bearing exterior leaf), loadbearing internal walls, and a tiled or metal roof. Some houses have discontinuous stone or masonry footings. Since most of the older areas are located in the alluvial basin, the most brittle form of construction was therefore combined with the worst foundation conditions.

Closer to the CBD there are areas such as the suburb of Cooks Hill where masonry terraced houses are common. In many cases, these have been extensively refurbished and altered with the removal of loadbearing walls, thus contributing further to the extent of earthquake damage.

For both the above types of construction, lime mortar is common, mortar joints are often soft and eroded, and earthquake damage revealed widespread wall tie corrosion. Although in some cases damage is relatively minor, in many cases it was quite severe. The nature of the damage can be summarised as follows: 
(a) Extensive cracking and deterioration of walls due to in-plane racking effects;

(b) Tilting of both loadbearing and non-loadbearing walls under the action of the transverse earthquake induced forces. In cavity construction, it was not uncommon for the non-loadbearing leaf to displace laterally at the top until it came into contact with the loadbearing leaf. In many cases where top and bottom support was adequate, bowing of the wall took place. Sliding of walls at damp-proof courses was also common. The lateral movement of the external skin often initiated in the masonry lintels above the windows, where there was less restraint against out-of-place movements;

(c) Partial loss of roof support due to movement of supporting walls. The ridge would then sag, due either to sliding across the top plate of the timber wall or as a result of the outward tilting of the supporting walls;

(d) Cracking of walls in flexure under the action of transverse load (typified by a double diagonal type of cracking pattern);

(e) Complete loss of external walls from the action of transverse forces. The result of corroded or inadequately anchored wall ties (or the lack of ties). This type of failure occurred in houses as well as in the two and three storey end walls of several groups of terrace houses;

(f) Gable end and parapet failure in terrace houses.

It is clear from the extent of damage sustained by houses in Newcastle, that there is a need for some minimum standards of earthquake resistant construction for housing. This is particularly the case for the more brittle form of cavity masonry construction which is still widely used in many parts of Australia.

\section{Masonry Design and Construction}

Examination of the damaged buildings has revealed some disturbing aspects with regard to the design of masonry, especially non-loadbearing elements. The responsibility for the design and construction of this masonry has been a subject of discussion over recent years [67]. Some of the aspects of concern include: (Figure 68-75):

(a) The majority of the damaged masonry-elements were so-called 'non structural' in nature, that is, the masonry had not been designed or inspected by a structural engineer when it was built. The detail was left to the masonry layer who followed so-called 'traditional' practices during construction. The damaged walls have revealed examples of poor detailing, under-strength mortars and poor workmanship.

To date, the specification for masonry construction was a matter for the architect or draftsman who was not concerned about strength of mortar, etc. This problem is not restricted to Newcastle. Faults have been discovered in the traditional masonry construction which appears in most parts of Australia. For example, in January 1991, consulting engineers Rankine \& Hill were involved in the investigation of masonry that had been damaged during the construction of a new public building in Sydney. The investigations revealed poor detailing by the masonry layer, who explained that what he had done was no different from what his fellow workers had traditionally been doing all over Sydney. If this is true, then there are serious implications for such masonry structures in Sydney, as well as in the rest of Australia, in the event of a minor or moderate earthquake, or even in the event of strong winds.

(b) The poor performance of mortar in masonry is of major concern [66]. It was discovered that masonry layers mix chemical and other additives to their mortars to make them workable and easy to use. Tests carried out at the University of Newcastle have revealed that the use of these additives was the cause for the poor bond strength identified in much of Newcastle's masonry construction problems. Some examples were so poor that it was possible to dismantle the damaged wall manually, and even to reuse the masonry by brushing off the mortar with very little effort.

(c) There are other chemical additives available in the market that allow good quality mortar to be made at no additional cost. However, even today in Newcastle, wrong additives are being used in large quantities on new building construction.

(d) This poor practice is still being carried out on projects where there is very nominal or no engineering inspections requested.

(e) The quality of wall ties that are used in masonry is also suspect. There are many areas around Newcastle that come under the category of being within a corrosive zone'. Buildings in these areas require heavy duty galvanised or stainless steel ties to be used. Unfortunately, in many instances the ties used are the cheapest available. In fact, if one considers the entire nation of Australia, the major urban population centres are all located close to the sea, an area highly vulnerable to salt water or industrial corrosion and, for which, extra pre-cautions in the use of adequate wall ties is required.

One of the reasons for the poor quality control of design, and material standards is the current fee structure for inspection of projects by professionals (engineers and architects). The clients, who are often builders and developers, are hesitant to pay for adequate inspections as they consider that it is not beneficial to them. In view of this Newcastle experience, the building industry has to seriously rethink its approach in order to meet its moral and professional obligations to the community at large. 
FIGURE 68

UNREINFORCED MASONRY BRICK WALL OF BUILDING IN BEAUMONT STREET, HAMILTON: POOR WORKMANSHIP AND INSUFFICIENT WATER IN JOINTS

(MARCH 1990; I.S.PEDERSEN)
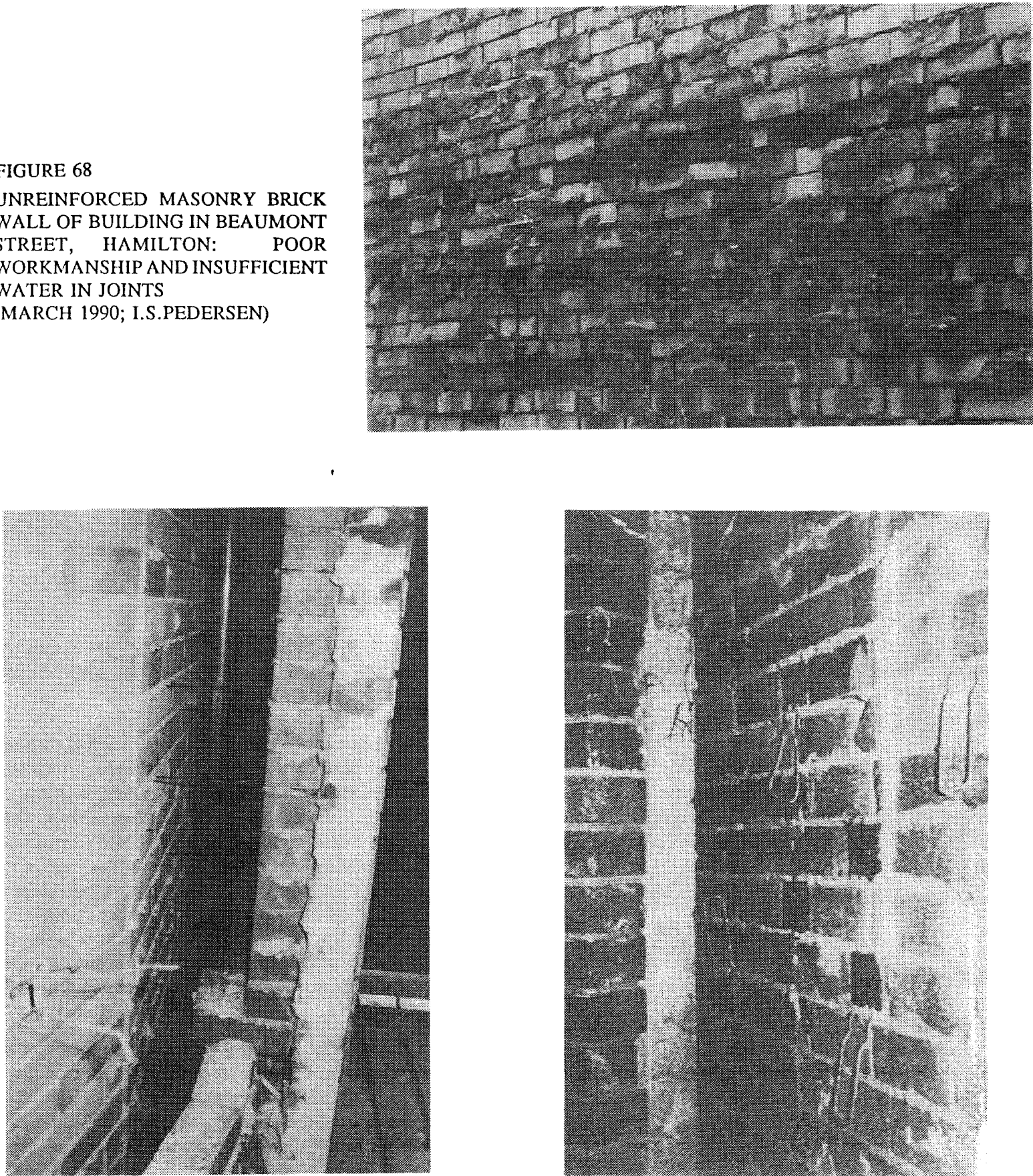

FIGURE 70

BRICK TIES BENT DOWN ANC NOT ENGAGED

(FEBRUARY 1990; A.W.PAGE)

CAVITY TIES FOR SPACING OF BRICK SKINS IN BUILDING. CONSTRUCTED IN 1970's. SMALLER GAUGE BRICK TIES THAN NORMAL, TIES DO NOT CONNECT AND THE SKINS AND CONSTRUC-TION AT CHANGE OF CAVITY WIDTH WITH UPPER BRICK WALL RESTING ON UNSUPPORTED BRICK ATOP LOWER BRICKWORK

(JUNE 1990; I.S.PEDERSEN) 


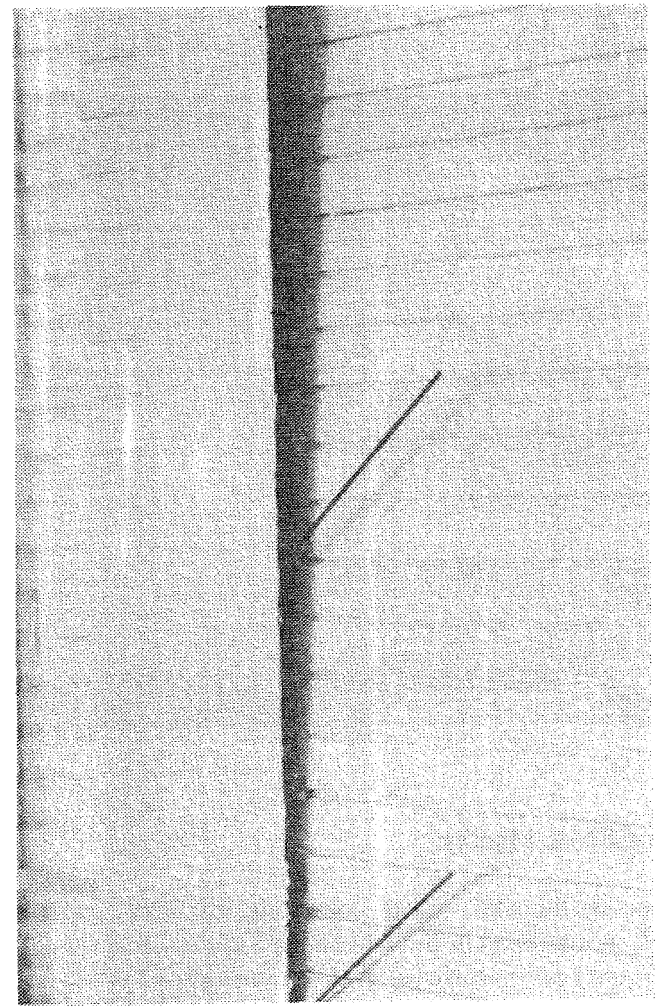

FIGURE 71

COMMON EXAMPLE (THIS CASE FROM HAMILTON RSL BUILDING), OF WALL TIES NEVER CONNECTED BY BUILDER AT TIME OF CONSTRUCTION RESULTING IN RELATIVE FAILURE OF MASONRY WALL SECTIONS (TIES SHOWN WERE EMPLACED IN ONE SECTION AND SIMPLY BENT UP PARALLEL TO THIS SECTION WITHOUT ATT $\triangle$ CHMENT TO ADJOINING SECTION. TIES WERE PULLED OUT FROM BEHIND WALL TO SHOW THIS PROBLEM).

(5.1.90; E.BRENNAN)

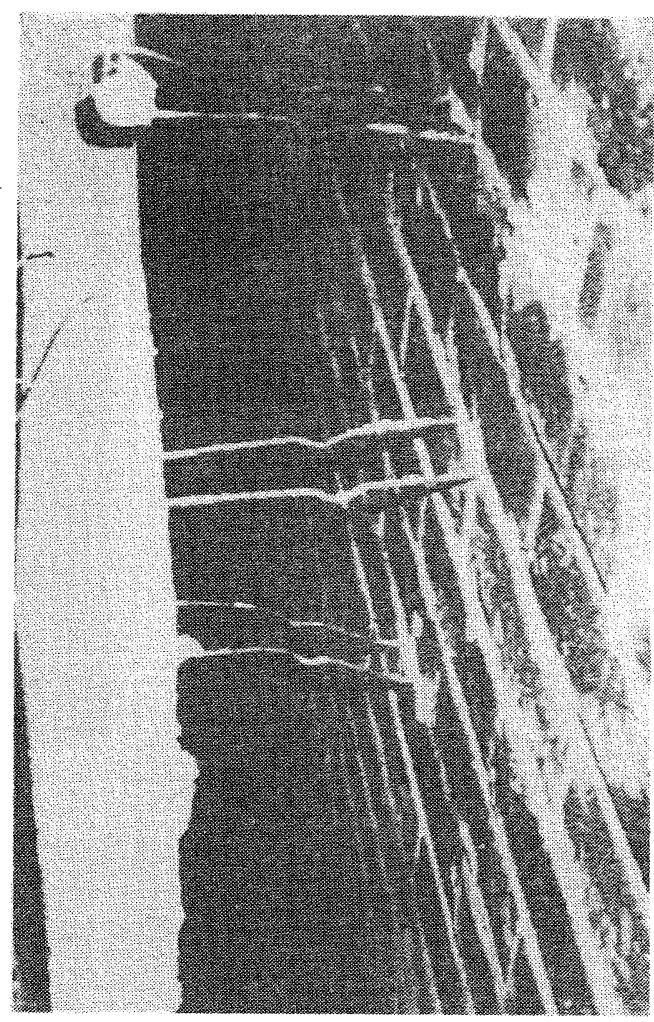

FIGURE 72

BRICK TIES TOO FLEXIBLE (FEBRUARY 1990; A.W.PAGE)

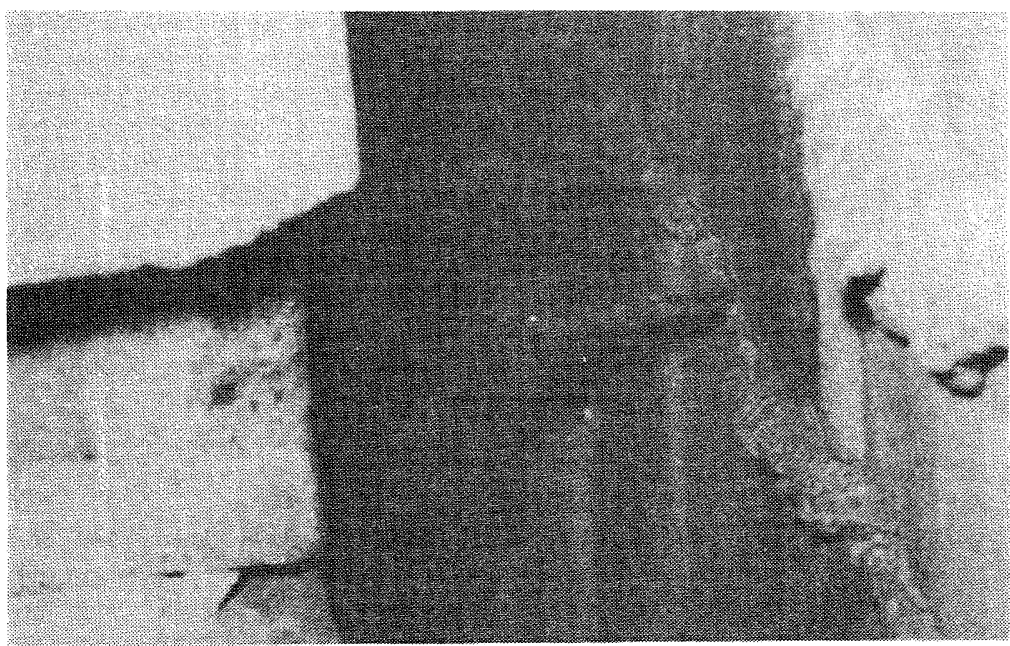

FIGURE 73

CORRODED BRICK TIES FOUND IN OLDER BUILDING, NEWCASTLE (27.11.90; I.S.PEDERSEN) 
FIGURE 74

TYPICAL DAMAGE TO BRICKWALL
IN BRICK VENEER PRIVATE
RESIDENCE (FEBRUARY 1990; I.S.PEDERSEN)

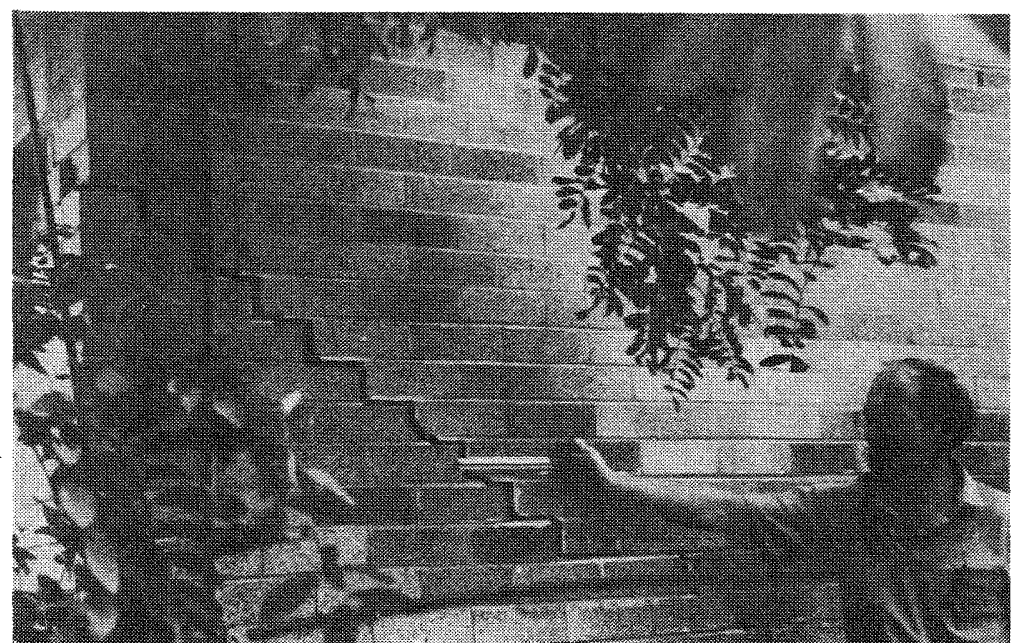

Masonry Block Mortar

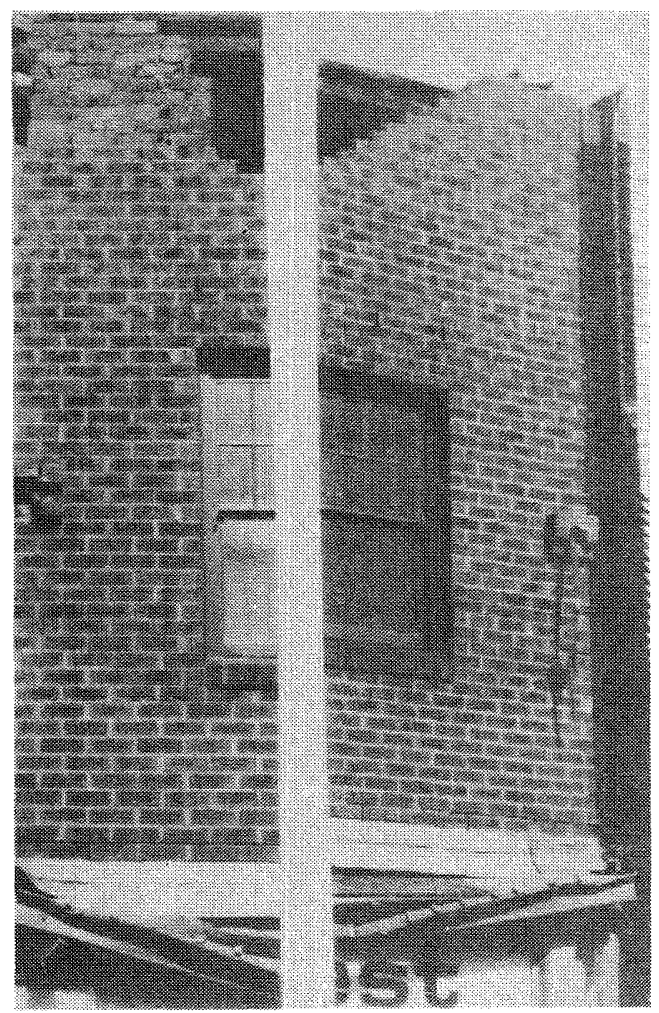

FIGURE 75

BLOW-UP OF FIGURE 38 (BUILDING IN BEAUMONT STREET, HAMILTON) TO SHOW TYPICAL FAILURE OF AWNINGS IN MANY PARTS OF NEWCASTLE WHERE IN EITHER AWNING TIE RODS BROKEN BUT STILL CONNECTED IN PART TO MASONRY WALL SUPPORTS (RHS) OR PULLED OUT OF WALL SUPPORTS (LHS) (4.1.90; C.R.FEATHERSTONE)
Since the earthquake, many consulting engineers have now required, as specified in the Australian Standard Masonry Code AS3700, tests on mortars for masonry and block masonry to be undertaken to ensure that their clients are being provided quality workmanship and product. The results of this testing have been alarming. The tests, undertaken by the University of Newcastle [68], have found that the traditional 1:1:6 (cement:lime:sand) mortar mix design have not attained the minimum characteristic flexural strength of $0.2 \mathrm{MPa}$ as specified by the Australian Standard Masonry Code. In a few cases, tests have achieved only 0.02-0.04 MPa. Typically a 1:1:5 mix with high grade additive "Dynex" (water thickener) for masonries and a 1:0:5 mix with high grade "Dynex" for blockwork has been found successful. These results are from the early days of research and far more work, such as that presently being undertaken by the University of Newcastle and others, is urgently required.

Much of the sand used to date in the mortar mix in Newcastle is beach sand which has a very poor grading, is absorbic and does not give good workability. Hence fire clay has been used - the only area in Australia, we know, which allows its use, but, since the earthquake, this has been banned by the Local Authority. Tests on the sand supplies in the region have found that grey washed sands from other sources relatively close by provide one of the few suitably graded sands. Discussions with masonry layers has found that "bush sand" or loam is the type used generally in other areas of Australia. To allow the light coloured beach sands to be used we have found that the additive "Dynex" (approximately 200 gms per mix), which is a water thickener, ensures that the minimum characteristic flexural strength of $0.2 \mathrm{MPa}$ is achieved. Building lime in the mix is advantageous for brick mortar, but current research shows that for blockwork, the lime should be eliminated from the mix to achieve the strength required.

\section{Damage Reports}

The procedure generally adopted in the earthquake refurbishment works in Newcastle has been to prepare a Damage Report. This Report basically listed the items of visible damage noted during the initial inspections. In many cases, when the Damage Report was accepted by the insurance company it was used as a basis to obtaining quotations from builders. 
The nature of masonry damage is such that invariably when the repair works are started, the demolition shows areas of additional damage that were previously hidden or revealed the presence of corroded or poor quality brick ties. The cost escalations in some cases are four or five times above the original estimate of the works. This procedure in many cases is the result of an unwillingness of the Insurance Loss Assessors on behalf of the insurance industry to pay fees for structural or building engineers to properly investigate and document the full scope of works and the nature of competition that the industry is demanding from the engineers. It is perhaps time to review this practice in the light of our experiences. It should be remembered that much of the work is engineering and the costs should reflect this, especially when compared to the fees paid to other consultants associated with the insurance industry.

\section{LOCAL GOVERNMENT RESPONSE}

The Newcastle City Council was the local authority responsible for the response to and recovery from the disastrous earthquake. This has included a recovery management plan regarding the processes of building regulation and hazard mitigation which was put into place some months after the earthquake.

December 28, 1989, was a typical summer day. Although it was a Thursday, the usually highly populated commercial areas were sparsely occupied, due to the school holidays and the traditional Christmas holiday period for many of the City's commercial enterprises. At $10.27 \mathrm{am}$ the earthquake struck. It lasted for about 5 seconds and measured 5.6 on the Richter scale. As a result, the statistics of death, destruction and devastation were like a nightmare never contemplated to be witnessed in Australia. On this day of Australia's first fatal earthquake, the City of Newcastle did not have a Disaster Plan. While events such as flooding, cyclonic winds and bushfires had always been capably addressed by the emergency response services and the local Council, the earthquake introduced new elements into the disaster response capabilities of the City.

The event, together with the Newcastle City Council's response, have provided many lessons to and subsequent solutions for all local authorities in seismic hazard mitigation for existing and proposed new buildings [69]. For obvious reasons, San Francisco, Los Angeles and other Californian cities, New Zealand and Australia's own city of Adelaide, instigated hazard mitigation programmes years ago. These cities have found that determining the engineering requirements for such purposes is but one of the elements required in positive risk reduction. Gaining community commitment to implement procedures requires consideration also of the social, administrative, legal, economic and the inevitable political factors which provide both constraints and support to the success of such a programmes. Immediate response December 28; 1989, saw the Newcastle City Council manned by a "skeleton" staff with all senior officers on leave - the normal accepted practice during such Christmas - New Year vacation periods in Australia. The Police and other emergency services had disaster plans for specific events but undoubtedly, like the rest of the community, no one was prepared for an earthquake or a natural disaster of the magnitude of the event of this day. Despite the recorded facts that two earthquakes of a similar magnitude had occurred in Newcastle in 1868 and 1925, seismic risk was given little recognition. In fact, building legislators had not even invoked the Australian Earthquake Code (AS2121-1979) in New South Wales building regulations.
At $3.00 \mathrm{pm}$ on that first day, after a meeting with the Lord Mayor, Town Clerk and Senior Officers, the Council's Director of Health and Building Services, (one of the authors HJS) was appointed Council's Damage Control Co-ordinator. The basis of the Co-ordinator's role was to instigate measures to ensure public safety and provide an orderly and efficient restoration of access to the affected areas of the City. It was also to act as the liaison point with the Police who had initiated their tasks of maintaining law and order in the disaster situation and manning the Emergency Operation Centre [70]. In normal times, a local authority has a responsibility to ensure that buildings do not present a danger to the public or the occupants. Legislation under the Local Government Act empowers any such local authority to take appropriate action to ensure that a danger is remedied by way of building repairs or demolition. Such action is also likely to include appropriate safety precautions in regard to the provision of hoardings to protect the public. The process involved in such action is prescribed, normally takes some time, and may involve a right of appeal by the owner against the service of the notice relating to immediate building repairs or demolition.

December 28, 1989, introduced new elements into disaster response and Council's responsibility for the control and regulation of buildings. In addition to the obvious considerations of public safety, matters such as emergency access, safety of emergency and assessment personnel and danger to adjoining properties were now relevant:- even more so in the event of an aftershock.

A preliminary assessment of the situation on that first afternoon indicated that many of the City's buildings were severely damaged. However, some services (power, water, sewerage, gas, telephone) were relatively unaffected, although electricity services were cut in some areas and communications in the Newcastle City area were limited to emergency use only. It was indeed fortunate in that the risk of fire was minimised as were any health or sanitation problems. Some post-disaster emergency buildings were damaged, including ambulance headquarters and some fire stations.

The state and extent of building damage determined a need for Restricted Areas (Figure 76). The Police established and manned an outer perimeter around the City and an inner perimeter which virtually closed off the CBD. Beaumont Street, Hamilton and sections of Maitland Road, Islington were also closed. Only emergency personnel were permitted entry into the CBD in the first few days. Property owners and their representatives were permitted entry thereafter.

A Control Headquarters was established on the 6th Floor of the Administration Centre, King Street, Newcastle, utilising the existing management structure of Council's Health and Building Services Division. The headquarters incorporated liaison with the Police and other emergency services. A vital link to the Control Headquarters was Council's Waratah Works Depot in the western part of the City, where the extent of damage was far less than in the CBD. Council's Services Engineer had the responsibility of organising the provision of safety barriers, traffic control and the removal of debris.

At the Council headquarters it was important to set up a Public Enquiry System. The next day, a rudimentary structure was implemented which consisted of an enquiry section and an inspection section. Shortage of staff was of prime concern at 
this stage and other Councils began to volunteer their officers. The system was quickly improved over the next few days as all of Council's regular staff returned from their scheduled vacations.

An Earthquake Information Centre was established on January 15, 1990, and operated until March 23, 1990. The Centre provided information from all the appropriate authorities and other services such as architects, solicitors, structural and civil engineers, builders and the insurance industry. In co-operation with the Department of Family and Community Services, the Centre answered thousands of enquiries for those people requiring assistance and advice.

During the first day it was obvious that a specialist media team was required to react to the high level of media interest, to serve the needs of the Australian public, both near and far, and internationally. It was also important that the Lord Mayor was fully informed and so could provide an interface with the public as the civic leader of the City. A professional media organisation was drafted to the Council staff. Together with the Town Clerk, regular media releases and press conferences were arranged and this allowed the Co-ordinator to concentrate on the task at hand at the time.

\section{Post Disaster Damage Assessment}

\section{Initial assessment}

The initial assessment of buildings was to determine which of those were dangerous to public safety. It should be understood that the maintenance of emergency access was imperative and the safety of emergency workers and inspection personnel needed to be assured. The possibility of an aftershock was ever present and related to all this was the problem of demolition or part demolition which needed to be addressed in the early stage. For this latter purpose a policy was quickly developed. Demolition work, by authorisation or by formal notice, was carried out in pursuance of the delegation already existing to the local authority under the Local Government Act, 1991.

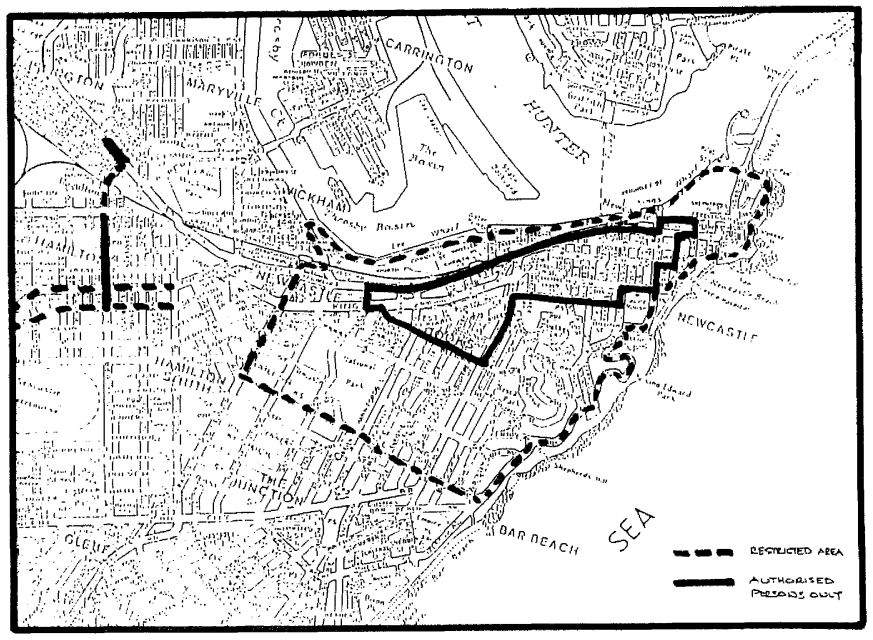

FIGURE 76 RESTRICTED AREAS IN THE CITY OF NEWCASTLE: INNER AND OUTER PERIMETERS BARRICADED AND MANNED BY POLICE
On Day 2 (December 29, 1989), the initial assessments commenced and were carried out by teams of Army Engineers in conjunction with Council Building Surveyors. (It should be noted here that over 100 officers from thirty Local Authorities throughout NSW and Brisbane volunteered their services in the first three weeks). The Army teams included military engineers and demolition experts, some of whom were experienced in damage assessment and so provided information on safety measures. These Army teams provided an immediate response to the need for early assessment and without their expertise and assistance many days would have been lost in achieving an acceptable level of public safety. These teams, each with a Newcastle City Council Building Surveyor, concentrated on commercial building damage in the $\mathrm{CBD}$ and at Beaumont Street, Hamilton, areas.

The CBD teams' prime objective was to ascertain those buildings which posed a threat to public safety. A secondary objective was to pinpoint those buildings which appeared unsafe for occupation. Residential damage was assessed by building surveyors with the assistance of specialist structural engineering advice where required. The major purpose of the residential teams was to assess the fitness of residential buildings for occupation and to provide assistance and advice to owners and/or occupiers in regard to any further action required.

A "Damage Code" was established to ensure a basic consistency with inspecting personnel. Four levels of damage were considered, each level designated by a particular colour-coded form (Figure 77):

$\begin{array}{ll}\text { RED } & \text { - Immediate Public Danger } \\ \text { AMBER } & \text { - Severe Damage, Possible Danger, Access } \\ & \text { Required } \\ \text { BLUE } & \text { - Damaged but habitable } \\ \text { GREEN } & \text { - Minor Damage }\end{array}$

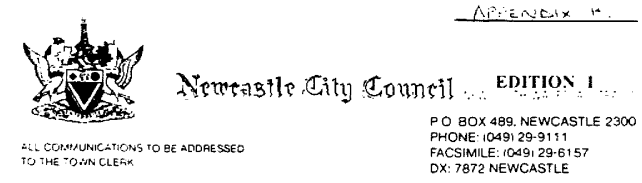

UNSAFE

DO NOT OCCUPY OR ENTER

\begin{tabular}{|c|c|}
\hline & DATE \\
\hline & TIME \\
\hline $\begin{array}{l}\text { WARNING: } \\
\text { THIS BUILDING IS DAMAGED } \\
\text { AND PRESENTS A DANGER. } \\
\text { DO NOT CROSS BARRICADES. }\end{array}$ & $\begin{array}{l}\text { THIS NOTICE WAS POSTED } \\
\text { UNDER EMERGENCY } \\
\text { CONDITIONS } \\
\text { UNDER THE AUTHORITY OF } \\
\text { THE TOWN CLERK }\end{array}$ \\
\hline DO NOT ENTER & \\
\hline $\begin{array}{l}\text { PROPERTY NAME AND } \\
\text { ADDRESS: }\end{array}$ & $\begin{array}{l}\text { DO NOT REMOVE THIS NOTICE } \\
\text { WITHOUT AUTHORITY FROM } \\
\text { THE TOWN CLERK }\end{array}$ \\
\hline & $\begin{array}{l}\text { NO DEMOLITION OR } \\
\text { RECONSTRUCTION WORK IS TO } \\
\text { BE CARRIED OUT WITHOUT } \\
\text { AUTHORISATION FROM THE } \\
\text { TOWN CLERK PH } 299306\end{array}$ \\
\hline & TOWN CLERK. PH 299306 \\
\hline
\end{tabular}

SIGNED...

EOR W B LEWI

FIGURE 77 EXAMPLE OF NEWCASTLE CITY COUNCIL "DAMAGE CODE" FORM: "RED" CLASSIFIED AS UNSAFE 
Details of the immediate assessment of damage to a specific building were recorded by Council officers on a "Damage Information Sheet" for each site inspected (Figure 78). This provided a valuable record for later reassessment (if required), codification of the building's damage state and was used in subsequent building repair applications.

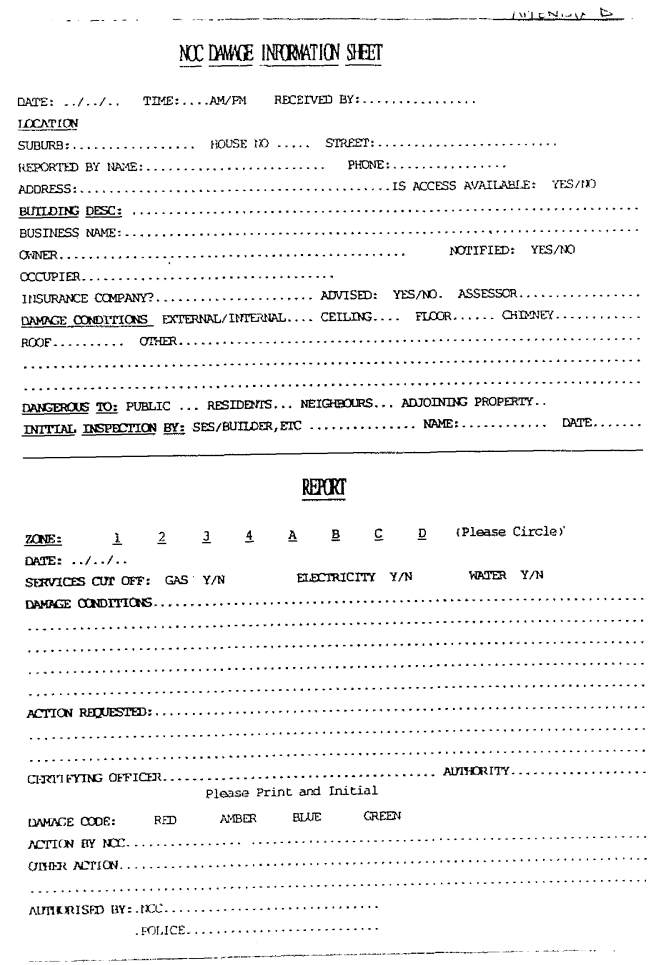

FIGURE 78 NEWCASTLE CITY COUNCIL "DAMAGE INFORMATION SHEET"

\section{Reassessment}

On Day 5 (January 1, 1990), reassessment of many of the damaged buildings, particularly in the CBD, was commenced. Council Officers were assisted in this task by a number of volunteer architects and structural engineers. While generally this process worked satisfactorily, there were enough exceptions to suggest that the value of this form of assistance needs to be carefully considered. The reassessment was aimed at providing a more comprehensive evaluation of the state of individual buildings and ensuring that any external dangers were located so that owners could be contacted regarding any necessary action. A degree of difficulty was encountered in gaining entry to many buildings, particularly those owned by absentee owners. In the reassessment, use was made of Red and Yellow posters based on a rapid evaluation of the buildings. Red was classified as "Unsafe" and yellow was classified as "Limited Entry". These posters proved to be confusing to some owners and an additional poster, Green for "Safe", may have avoided the confusion.

\section{Follow-up inspection}

Follow-up inspections were carried out for weeks after as damage worsened on some buildings due to ground movement, rain and wind and in situations where owners sought advice in regard to demolition or part demolition. Formal notice procedures were enforced after the first few weeks where no action was taken by owners to carry out remedial works and/or provide suitable hoardings in accordance with the requirements of the Department of Industrial Relations.

\section{Heritage and significant buildings}

It should be noted that listed heritage buildings and other buildings of significance were meticulously assessed. All heritage buildings were identified on the Control Headquarter's disaster map on the morning after the earthquake. Demolition or part demolition occurred only when necessary and where the safety criteria were being jeopardised.

There are over 200 listed heritage buildings in Newcastle, of which three have been demolished. Two seven storey buildings, not heritage listed but of significance, were demolished on instructions by formal notice within the first few days after the earthquake. The Co-ordinator's decision for this demolition was based on several structural engineering reports and the concern for emergency and assessment personnel, particularly in case of an aftershock. These buildings were also in close proximity to occupied buildings and other buildings of listed heritage significance. Other buildings of less height (2-3 storeys) which were of significance were barricaded to ensure public safety and provide more time for closer assessment.

The misconception that there was wholesale and wanton destruction of the City's heritage buildings was fuelled by sensational media reporting and by what appeared to be a group of local political opportunists. Naturally, a number of buildings have been demolished since the early days of the disaster and their demolition was associated with building economics and insurance cover which, in many instances, were a major consideration. The alternative to demolition was to let the buildings stand idle and deteriorate over time.

Another factor relating to the retention of these buildings is the requirement for earthquake resistance which would become an added expense. The Newcastle City Council worked closely with structural engineers and architects to ensure that those buildings that require repair would meet both resistance and aesthetic standards expected by the community.

\section{Public health procedures}

It has been previously indicated that lifelines (power, water, sewerage, gas, telephone services) were relatively unaffected and so minimised potential health and sanitation problems. A small health unit was established, however, to ensure that any possible problems were prevented. Within three days of the earthquake, the unit had contacted owners/occupiers of all food premises within the restricted areas and, with their co-operation, removed all putrescible products from the premises. During this time, the Council's pest control teams were utilised to carry out control programmes throughout the City, with particular emphasis on severely damaged sites which in many cases were no more than heaps of rubble. 


\section{Re-opening of The City of Newcastle}

A target of opening the CBD was set for Day 12 (January 8, 1990) and a strategy for progressive perimeter reduction was set with the Police. It was obvious at this stage that ground settlement was still occurring and "new" damage to buildings was becoming evident. This was of concern, particularly in regard to the objective of making the City "safe" for access by January 8, 1990. Regular "perimeter" meetings were held and reductions were made as targeted. The CBD was opened as planned. While the mammoth task of rebuilding the City commenced within days of the earthquake, several years will be required to achieve normality in terms of the physical environment - so too, with the problems of post-disaster trauma that the community was then desperately trying to come to terms.

\section{Recovery}

Predictably, within weeks of the earthquake, the community was tired and frustrated. The problems associated with the physical rebuilding process were creating uncertainty and anger amongst the general public and officials alike and this added to extreme trauma evident in the community. A sunset committee was set up by the Newcastle City Council to develop a "Recovery Plan". The following extract from the Report of Council's "Earthquake Renewal Sunset Committee" describes the situation some 12 weeks after the event:

"Three months after the December 28 earthquake, the Newcastle community was clearly and predictably tired, frustrated and angry.

There was a discernible absence of leadership, mainly because there were many diverse authorities, engaged in earthquake recovery and no obvious co-ordination or public explanation of what was happening.

The pressures on these authorities from day to day matters were enormous and threatened to overwhelm strategic and communication objectives, particularly in some key areas where there was a critical shortage of staff.

Clearly, the management of the recovery process and communication of this process emerged, three months after the earthquake, as an urgent priority."

Newcastle City Council had a key leadership role in co-ordinating and managing the recovery process. This stems largely from its statutory obligations, but also from the status of Aldermen as the responsible elected representatives of the community. Both Federal and State Governments had indicated that no new organisation would be introduced to oversee the renewal and the City Council was the only appropriate organisation for detailed co-ordination of the renewal process.

Council adopted a Renewal Management Plan based on the following management approach:

to acknowledge that various authorities have specific tasks in the recovery process and are performing these; to co-ordinate knowledge about these various activities to provide an overview of how Newcastle is progressing in the renewal process, and to identify areas of special need or success; to communicate this information to various audiences, including government, media and the community generally on a regular basis;

The key areas of the renewal process concern "people services", the built environment and strategic planning, with each of these being complicated by the peculiarities of their respective histories and the existence of several major players.

A Renewal Co-ordination Unit was established in September 1990 and is expected to function at least until July 1992. The key roles of the unit are to:

(a) Co-ordinate and facilitate those activities of Council, community organisations, State/Federal Governments and individuals which are crucial to the recovery and renewal of Newcastle and its people;

(b) Co-ordinate a comprehensive bank of information concerned with the earthquake of December, 1989;

(c) Achieve a balanced and equitable expenditure of compensatory funds and contributions to all those affected by the earthquake;

(d) Promote new investment in, and development of, the built environment of Newcastle and district which is both sympathetic to, and in harmony with its surroundings;

(e) Conserve a built environment in Newcastle and district that reinforces the ambience necessary to maximise renewal;

(f) Keep Council, and the people of Newcastle and district, involved in and regularly informed of the progress of actions designed to promote renewal.

\section{Building Reconstruction}

While an earthquake of the recorded magnitude was considered moderate, its importance to Australian and overseas authorities is that it struck in an area where the seismic risk was given no recognition and it caused significant damage. Despite the history of seismic activity, the risk has never been considered in formulating building regulations or design practices either in this City or in New South Wales generally. There was an urgent need to set interim requirements to provide guidelines for new buildings and address the upgrading and maintenance of existing buildings. The urgency was highlighted by the amount of repair and redevelopment work that was quickly undertaken without formal guidelines in regard to earthquake resistant construction. National and State standards and legislation will obviously be reviewed in light of the Newcastle earthquake. However, it could take some time for any amendments to be affected.

\section{Interim building requirements}

Interim requirements adopted were based on the objectives of ensuring public safety and safeguarding against major structural failure with resultant loss of life. It should be noted that most major damage is associated with older and unreinforced masonry structures and that buildings designed and constructed in accordance with modern Australian building standards generally performed well. Briefly, these interim requirements are:

\section{New buildings}

Requirements based on the current Australian Earthquake Code AS2121-1979 [22] buildings in Zone A, with the exception of post-disaster buildings, whereby it is required that construction be in accordance with Zone 1 requirements. In regard to domestic housing, no specific requirements are specified for 
single storey dwellings; however, it is emphasised that strict compliance and supervision of current building regulations is necessary. It should be noted that regardless of building classification and earthquake zoning, special attention is required for filled sites and areas of soft alluvial soils and that designs of structures in these instances will need strict recognition of geotechnical data.

\section{Existing buildings}

The extensive damage to brick parapets and awnings of commercial buildings highlighted the need for the upgrading of buildings which were potentially hazardous, to ensure public safety in any future occurrence. Upgrading is not a simple task for either Council or the building owners and a reasonable period of time needs to be allowed. Five (5) years has been suggested; however, this should be flexible, based on the circumstances of each situation. Upgrading requirements are based on similar standards adopted in San Francisco and Los Angeles. Training programmes are being developed for the building industry and are designed to develop an awareness of the interim building requirements and approved building techniques in regard to earthquake resistant construction. These programmes will not only target tradesmen but also architects and structural engineers. Earthquake hazard mitigation is being prioritised and addressed over a period of time.

\section{Latent and recurring defects}

It has been recognised that ground settlement, impending summer weather conditions and intense heavy rains would continue to expose building defects not already identified [18]. Such conditions saw high levels of recurring damage particularly to those buildings that were repaired in the first few weeks after the earthquake (discussed in detail later). This problem is of particular concern to the insurance industry and, through the instigation of the New South Wales State Minister for Housing, a Taskforce representing all facets of the building and insurance industries have developed appropriate guidelines to rectify the situation relating to latent and recurring defects.

\section{Awnings, verandahs and balconies over footpaths}

Post-earthquake rebuilding revealed the need for a review of Council's policies relating to the control and regulation of awnings, verandahs and balconies erected over public footpaths. The major considerations to be addressed were those of structural integrity (as many awnings, verandahs and balconies failed or are considered hazardous and require upgrading) and, as proposed in Council's Beaumont Street Urban Design Study, to provide the opportunity to enhance or create a traditional appearance to buildings. A policy was approved by Council in June 1990 with the objectives: (a) to provide guidelines for the location, design, construction and upgrading of awnings, balconies and verandahs; (b) to ensure that any awning, balcony or verandah subjected to natural or man-made destructive forces will not present a particular threat to life, health and welfare of the public; (c) to allow scope for architectural freedom and subsequent encouragement for the erection of awnings, balconies and verandahs to complement the built environment whilst providing incentive to property owners to reconstruct awnings on older buildings. These guidelines for such detailing could be relevant to all construction in Australia and the maintenance thereof should become mandatory.

\section{The City's Renewal}

The City of Newcastle is well on the road to recovery. The Renewal Co-ordination Unit's Status Report as at June 1991 [32] states that "Whilst problems still exist, and will do so for some time, there are many real achievements which can be recorded." Following the immediate response to and initial recovery from the earthquake, building reconstruction was addressed. After the first year, with building reconstruction continuing, the renewal, or community reconstruction, began. Significant visible progress in the social, economic and physical aspects of the City is evident in both the public and private sectors. Side-by-side with the re-establishment of the pre-earthquake built environment, new developmental projects have come to the City. Although such renewal is recognized and accepted as being a long process with major changes having to be made to the urban fabric, it has been totally accepted that it will provide for a better Newcastle in the future.

\section{INSURANCE ASPECTS}

The vulnerability of Australia's urban environments to the devastating potential of earthquakes was dramatically witnessed with the Newcastle event. Such loss potential from natural disasters, including earthquakes, in the highly populated and industrialised coastal regions of nearly all countries in the world has been recognised in the international insurance arena, primarily through the research of major reinsurers [57]. Australia's insurers have virtually neglected the response to earthquake exposure, as aptly stated by $L$. Lester of the Insurance Council of Australia (ICA) [71].

"This industry (in Australia) has always regarded
earthquake as the "sleeper" among the natural hazards
which regularly play havoc with insurer's loss ratios.
Insurers always had an uneasy feeling that one day the
big one "would happen", but because of lack of
knowledge and their seeming inability to interpret the
signals from past events, little was done by underwriters
to attempt to assess the likelihood of a major earthquake
in a highly populated area.

Few in the industry understood the importance of building construction principles in mitigation of earthquake damage, nor the influence of soil types on the transmission of even moderate shocks.

Consequently, the risk of earthquake remained part of practically all property policies issued in Australia and certainly, in the case of domestic insurance, without payment of premium."

As is well known, Australia is well versed in handling other natural disasters such as cyclones, floods or bushfires. These have been considered as major losses but it was the Newcastle earthquake that brought the meaning of "catastrophic" loss into reality, as stated by C.Henri (ICA) [72]:

"The Newcastle earthquake has changed forever the insurance industry's perspective of catastrophic loss ...... It was a very sharp lesson for apathy and complacency".

The earthquake loss can be put into some historical perspective by considering the major insured losses from natural disasters in Australia for the period June 1967 through December 1990 (ICA data; L. Lester, pers.comm., 1990), as shown in Table 9 [73]. 
TABLE 9 INSURED LOSSES FROM NATURAL DISASTERS IN AUSTRALIA JUNE 1967 JANUARY 1990: ICA DATA

\begin{tabular}{||l|c|}
\hline \multicolumn{1}{|c|}{ MAJOR DISASTER } & $\begin{array}{c}\text { LOSS \$AU(1991) } \\
\text { BILLION }\end{array}$ \\
\hline Total Loss for 25 year period & 5.0 \\
Losses from all earthquakes \\
which include the specific disasters: & 1.5 \\
1974 Brisbane - Cyclone "Wanda" and Floods & \\
1975 Darwin - Cyclone "Tracy" & 0.27 \\
1983 Victoria and South Australia - Ash Wednesday & 0.69 \\
bushfires & \\
1985 Brisbane - Storms & 0.27 \\
1989 Newcastle - Earthquake & 0.25 \\
1990 Sydney - Hailstorm & 1.2 \\
\hline
\end{tabular}

Earthquake losses amount to about $30 \%$ of the total insured loss over this 25 year period. Prior to the Newcastle earthquake, total losses were about \$AU(1991)100 million, of which about \$AU(1991)70 million was claimed in the 1954 Adelaide earthquake [73]. Clearly, the Newcastle earthquake has made its point in being the most devastating of all natural disasters in Australia with insured losses of (late 1991) \$AU(1991)1.0 - 1.5 billion.

The Newcastle earthquake came as a most unpleasant surprise to the industry for many reasons: its occurrence in an area of supposed "low risk"; buildings considered relatively storm-proof and fire-resistant did not withstand the earthquake; the reality of the state of the building stock (both commercial and residential) in terms of age, quality of construction and deterioration; influence of soil types on damage potential; lack of examination of underwriting conditions with time (many buildings insured under Re-instatement and Replacement Conditions should have been insured under Indemnity Conditions). Several aspects, integral in the above, have been identified for special attention:

\section{State of the built environment}

This has been fully described in terms of the damage sustained and the subsequent reports from the engineering community and building consultants retained by the insurance industry [74]. Not only were the buildings old with clear signs of deterioration but also many were poorly maintained, inadequately constructed often with insufficient foundation structures. Problems with the foundations appeared and were of major concern from the first day. It was a major reason in the case of many demolitions (in respect of public safety) and continues to be a delicate issue in relation to required upgrading or complete replacement to comply with current local government building ordinances. To these structural aspects were added the considerable amount of damage to internal fixtures, fittings and furniture in both commercial and residential buildings. In the assessments of the "immediate" earthquake damage, it was discovered that considerable pre-existing unrepaired damage was present. In the main, this was due to lack of maintenance of the building but there were several cases that were considered to be the result of the previous 1925 earthquake in Newcastle. It also included the problem of inadequate footings to the buildings.

\section{Latent and recurrent damage}

This is a most serious issue, both economically and socially, to be addressed as time goes on. (A separate section follows giving further details). The question is - "was it earthquake damage or was it not?" This is a complex issue containing several factors, seemingly separate but also integral to one another in part. These include continuing ground movements as the Earth returns to some "state of equilibrium" with time, further effects on pre-existing damage, further damage to repairs already completed, complications resulting from the heavy rains which seriously affected the Newcastle region at the end of January - early February 1990, existing ground conditions that may relate to shrinkswell conditions of the soils and the water table and time-frame for receipt of damage claims. As aptly stated by A. Morgan [75], "the early situation was only the tip of the iceberg, the real problem lies beneath the surface".

\section{Underinsurance}

This was the major issue confronting the affected people when they learnt that they did not possess adequate insurance cover. ICA estimates that up to $70 \%$ of dwellings were underinsured which included, in the worst affected areas of Newcastle, a range of 30\%-50\% on residential buildings and about $30 \%$ on commercial properties [72].

\section{Supply and demand of services and materials}

The massive extent of damage in Newcastle produced a severe demand on the services of loss adjusters and the building industry and the supply of building materials. Many problems have arisen from loss adjusting which were subsequently manifested and sometimes magnified, in the physical repair work. Although the self-regulating industry's Master Builders' Association (Newcastle Branch), in conjunction with the insurance industry, strove to ensure a high standard of workmanship, there were many cases of unqualified and inexperienced repairers arriving on the scene.

Additional strain was put on the insurance industry and its associated industries with further major natural disasters that occurred in the post-earthquake period. These included the March 1990 hailstorm and January 1991 thunderstorm in Sydney. Together with the Newcastle earthquake, these have resulted in the servicing of nearly 200,000 claims [72].

\section{Fraud}

Although fraud is a human element that the insurance industry has and no doubt will always have to deal with, and so is not unexpected in the aftermath of a disaster, the massive scale of fraud resulting from the Newcastle earthquake is staggering. It became necessary to implement a special Police Insurance Fraud Unit in Newcastle to deal with this problem which is now in the province of the Courts [72].

As at the end of 1991 , about 69,000 insurance claims have been lodged, comprising 7,000 commercial and 62,000 domestic [72]. 
Potential earthquake losses in the future can now be placed in some perspective. Following the $1954 \mathrm{ML} 5.3$ Adelaide earthquake, J. Staveley(AMP, Sydney) projected the 1954 losses into 1986 terms (in reference to Adelaide) with extrapolations for larger magnitude, and hence greater damage, occurrences [76]. Using Staveley's method, expected losses for the 1989 Newcastle earthquake, based on the observed damage and hence assigned intensities (MM $\geq \mathrm{VI}$ ), were calculated and losses for a similar ML5.6 earthquake in the major Australian cities of Sydney, Melbourne and Brisbane projected (Table 10; [73]). The calculated insurance losses for the 1989 Newcastle earthquake was estimated to be about \$AU(1991)1.5 billion extremely good agreement with the actual losses of about \$AU(1991)1.2 billion. Based on the same assumptions, the losses are projected to be about $\$ A U(1991) 10$ billion from Sydney \$AU(1991)5.5 billion for Melbourne and \$AU(1991)3.5 billion for Brisbane. In some quarters these are considered conservative, certainly so, if one considers a large and potentially more damaging earthquake (whereby the effects, including loss estimates, could be greater by a factor of 3-5). Despite many "economic" errors that may be considered in the calculations, possibly totalling $+25 \%$, the urgency to recognise this ever increasing projected damage potential [57] is a vital consideration for urban communities.

\section{LESSONS LEARNT}

Notwithstanding or diminishing the socio-economic effects of the trauma, community costs and the renewal processes, the 1989 Newcastle earthquake has provided the community with many lessons in all disciplines by which future earthquake disasters can be handled with greater professionalism and less human drama. These can be briefly summarised as follows [3]:

\section{Geological lessons}

- need for detailed mapping of urban areas

- need to collate all available data

- surface geology control in potential damage

- need for greater understanding of continental tectonics deep structure and processes

- importance and likely location of amplification and liquefaction

\section{Seismological lessons}

- limitations of earthquake parameter determinations - need to understand earthquake source in more detail

- necessity of longer term instrumental coverage for aftershocks

- importance of community damage and felt reports

- closer liaison with engineering requirements

- need for a more reliable and applicable earthquake load code

- need for improved instrument networks to cover urban areas

TABLE 10 PROJECTED INSURED EARTHQUAKE LOSSES IN URBAN AUSTRALIA

(Based on losses from 1954 Adelaide earthquake; Staveley, 1986)

\section{ADELAIDE EARTHQUAKE ML5.3}

Assessed building (brick) damage assigned MMV

Insured loss

1954 Contemporary values

1986 Adjustment for increase in domestic housing 132,000 (1954) to 321,000 (1986)

and in Australian dollar $\$ 1$ (1954) to $\$ 6.50$ (1986)

Loading $25 \%$ for replacement value rather than indemnity

1991 Adjustment for increase in Australian dollar \$1 (1986) to \$1.34 (1991)

Projected loss for greater earthquake based on AS2121 (1979) (from Table 2; Staveley, 1986)

1991 MM VI (x 3)

MM VII $\quad(x$ 9 $)$

MM VIII $\quad(x$ 25)

MM IX (x 60?

Insured loss

199

Domestic housing (Newcastle and environs)

Insured loss for actual damage in eathquake from assigned MM intensity

values (Rynn, 1990) based on 1954 Adelaide earthquake alone

Probable earthquake risk increase from AS2121 (1979) to recent (Rynn, 1989)

Loading for commercial losses

Loading for wealth factor (1970 to 1990)

ACTUAL insured loss (ICA estimate, 1991)
LOSS \$AU

$1954 \$ 6$ million

$1986 \$ 94.8$ million

$1986 \$ 118.2$ million $1991 \$ 158.4$ million

1991 \$ 0.48 billion $1991 \$ 1.43$ billion $1991 \$ 3.96$ billion $1991 \$ 7.09$ billion

\begin{tabular}{|c|c|}
\hline 300,000 & \\
\hline $90 \%$ MMVI $-\$ 0.43$ billion & $1991 \$ 0.57$ billion \\
\hline $\begin{array}{l}\text { 10\% MMVII - } \$ 0.14 \text { billion } \\
\text { factor of } 2\end{array}$ & $1991 \$ 1.15$ billion \\
\hline - $\$ 0.12$ billion & $1991 \$ 1.3$ billion \\
\hline - $\$ 0.25$ billion & $\begin{array}{l}1991 \text { \$ } 1.5 \text { billion } \\
1991 \text { \$ } 1.2 \text { billion }\end{array}$ \\
\hline
\end{tabular}

Considering erros in estimates to the $\pm 25 \%$, the agreement between extrapolation of Staverley's (1986) estimates and the actual loss for the 1989 Newcastle earthquake is excellent.

\section{OTHER URBAN AREAS IN EASTERN AUSTRALIA (AT 1991)}

Based on the 1989 Newcastle earthquake assigned intensities and considering all other factors being equal in these projections (brick houses, urban geology (alluvials, expansive clays, rock), age of buildings, style of construction, value of buildings, loading factors as above and wealth factor (1970 to 1990) of 50\%):

City

Sydney

Belbourn
Housing estimate

1.5 million

1 million
0.6 million
Projected insured loss $(+25 \%)$

$1991 \$ 10$ billion

$1991 \$ 5.5$ billion $1991 \$ 3.5$ billion

The author acknowledges Mr John Staveley (AMP, Sydney) for his contribution in preparing this Table. 


\section{Engineering lessons}

- need to integrate geology in geotechnical understanding amplification, liquefaction, long-term effects

- improve quality of materials used in construction

- improve construction standards and management

- consider need for seismic reinforcement and building conservation

- understanding of Codes and their application by the construction industry

- lack of communication between building design and construction practice, including inspections

importance of latent and recurring building defects

vulnerability of urban environments to continental (intraplate) earthquakes

\section{Local Government lessons}

- hazard mitigation - are we prepared?

- building maintenance or lack thereof - needs responsibility

- implement provisions for post-disaster damage assessment improve building standards and quality control

- assess role of local government in disaster management

\section{Construction lessons}

- need to correctly identify damage and/or defects and determine adequacy of the scope of work

- ascertain validity off the repairer's licence?

- degree of protection needed against eventuality of repair defects and/or recurrent fracturing

- need for adequate provisions for the longevity of repairs beyond New South Wales Building Code (Ordinance 70) or its equivalent, or the Australian National Building Code

\section{Legal lessons}

- responsibility for compensation covering natural disasters

- responsibilities of builders, designers, structural and building engineers and local authorities in the building process

- responsibilities of insurance companies

- who has the responsibility for existing potential earthquake hazards?

- where does heritage legislation fit into disaster damage?

\section{Insurance lessons}

- assess adequacy of insurance cover

- know your policy (!) - replacement or indemnity, different underwriting principles?

- the role of loss assessors - do they know the state and extent of building damage and the role of building professionals in the industry?

- need for accurate claims

- assess qualifications of tradespeople, builders and repairers generally

- $\quad$ speed of reconstruction

- ability of certain professionals to deal with light frame construction under earthquake conditions

- understand effects of climate following an earthquake when is it earthquake damage, or not?

\section{Emergency Services lessons}

- need for effective systems of communications

- need to identify potential hazards and emergency services' reactions to them

- effectiveness of manpower management

- continue on-going emergency planning and hazard mitigation.

\section{SOME QUESTIONS AND MISCONCEPTIONS}

The immediate effects of the earthquake were compiled in The Institution of Engineers, Australia, summary publications [8,9] prepared soon after the event, with reports from specific authorities such as the Newcastle City Council, State Government of New South Wales and emergency services agencies following in the ensuing months. This included a review in the NZNSEE Bulletin [34]. These reports concentrated on the City of Newcastle and the consequences for the City in the immediate aftermath of the earthquake. Many questions were raised in the immediate post-earthquake period and studies began to address them. The progress results of some of the multidisciplinary research have been disseminated through conferences such as $[2,3]$ and the recent NZNSEE Pacific conference on Earthquake Engineering (Auckland, November 1991), all reports are in reference to the Newcastle City region.

Several other papers by various authors have also been published. Unfortunately, some of these papers with their inferences have been treated as "gospel" in several quarters. This is causing concern particularly amongst practicing structural engineers who are the principal players in the reconstruction and renewal programmes. The basic problem is that of not taking account of all the available data in the fields of earth sciences and engineering. Most cases only refer to the effects in the City of Newcastle, indeed specifically referring to particular "streets" within the CBD and Beaumont Street, Hamilton. No cognisance is taken of the "outer" suburbs of the City of Newcastle, the City of Lake Macquarie, adjoining shires/cities and the far-field effects on Sydney and more-distant country areas. Within this context, the complexities of integrating all disciplines and their specific data sets must be recognised and addressed. Some aspects of question and concern are discussed below.

\section{Seismological Questions}

Engineers have questioned seismologists as to the earthquake source location [11] and radiation pattern [9] in relation to a correlation with the observed damage pattern in the epicentral region (Figure 56). The first part of the answer was the realisation by the "practical users" of the seismological information of the uncertainties in earthquake location, focal depth and focal mechanism. This is particularly evident in Newcastle's case because of the poor seismograph station distribution and the apparent lack of geological and tectonic information available to the seismologists. In Australia, and indeed several other continental regimes, such concerns can be better addressed by the integration of all available data and not of a selected set of the data. This is the first of many instances pointedly referring to the use of all available data to avoid any misconceptions in the use of resulting analyses for commercial purposes.

\section{Cause-Effect Relations from the Immediate Damage}

The causes of damage at the time of the Newcastle earthquake can be broadly classified as: (a) building construction defects which include age, design, construction practices and lack of maintenance - as discussed in detail in earlier sections and about which there is full agreement and acceptance; (b) geotechnical considerations which include geological controls of sedimentary surface deposits, distance from epicentre (effectively attenuation), frequency of ground motion, amplification, 
liquefaction - all of which are fundamental to the assessment of the earthquake hazard and hence the vulnerability of buildings and lifelines to earthquake loads. It is this latter cause which, in some instances, is the subject of misconception and so worthy of serious debate.

The first step is that of understanding the geology, more specifically, the definition of surface sediments (or alluvial deposits). Geologically, alluvials are derived from both in-situ material and weathering of rock with intermixing of organic material and include aeolian (wind blown), fluviatile (fresh water), marine and glacial deposits. The "surface soil" layer is a very thin weathered horizon (the A horizon). In geotechnical engineering terms, the "sediment" is any material not lithified, usually considered as a mixture of clay, sand and silt, whether it be a geological "soil" or "alluvium" - that is, a very non-geological consideration. In the Newcastle area, the alluvials are up to about $35 \mathrm{~m}$ thick overlying the competent bed-rock of the Newcastle Coal Measures (the original rock fabric).

In the following comments on some of the geotechnical issues, particular reference is made to the studies by Coffey and Partners International Pty Ltd [9] and by the UK-based Earthquake Engineering Field Investigation Team (EEFIT) in relation to the Newcastle City region. There appears to be some confusion as to the alluvial thickness (called "soils" in some reports) being a "correlative cause" with the extent of building damage. While the Coffey study suggests some correlation between the damage pattern and greater thicknesses of alluvium, the EEFIT study sees no such correlation between the damage pattern and alluvium thickness, albeit this latter study [36] being based, in part, on the data given in [9]. The alluvial thickness contours in [9] are based on only 31 boreholes throughout the entire City of Newcastle. Indeed, there are several pockets of serious damage (other than the CBD and Hamilton; after consideration of the totally available data set), such as Hexham (approximately $14 \mathrm{~km} \mathrm{NW}$ of the Newcastle CBD) and Holmesville (approximately $18 \mathrm{~km} \mathrm{~W}$ of the $C B D$ ), which occurred on (presumably) many varying thicknesses of alluvium (Holmesville, a few metres thick; Hexham, many tens of metres thick). It is proposed herein that either case cannot be satisfactorily considered until more detailed borehole information becomes available.

The confusion then extends to amplification of the seismic energy on the alluviums. The effect of amplification in sediments is a well known phenomena for earthquake damage, for example, in Mexico City this has been specifically cited to explain the effects from the 1985 Michoacan earthquake. Amplification factors ranged between 8 and 56 (with one of 75) for natural periods between 1.4 and $4.8 \mathrm{sec}$ [77]. (Note that [36] states a factor of 6 in Mexico City.) Direct comparisons between the effects in Newcastle and Mexico City should not be made, as the former is dealing with the near-field (higher frequency ground motions; short epicentral distances 0-30 km) while the latter with the far-field (lower frequency ground motions; long epicentral distance $300-400 \mathrm{~km}$ ). However, use is being made of the comparisons for the far-field damage effects of the Newcastle earthquake. The critical element in amplification is the velocity contrast between the alluvial sediments and the underlying bedrock and not the thickness of sediments (as discussed earlier and as detailed by studies in the eastern USA [58]).
Questions should be raised as to the approach taken by [36] using theoretical site response analyses to assess vulnerability of building stock in other continental areas, based on a selection of the Newcastle data set. The assumptions used in the calculations of ground motion velocities and accelerations in the Newcastle case were the selection of ground motion from an ML 5.5 Honshu (Japan) earthquake (a plate-margin situation) and attenuation relations for the eastern USA. Are these conditions applicable to the 1989 Newcastle earthquake? (Indeed, the accelerogram and attenuation relations selected should have been explicitly cited in the EEFIT study [36] to assess the relevance and so make a more detailed consideration of their conclusions.) The selection of only five of the set of borehole data [36] is considered not a sufficient sample for such considerations as it is well known geologically (and indeed clearly evidenced in the available data of the Coffey study [36] that alluvial thickness is widely variable across the Newcastle City region).

In an earthquake, the amplification effect is considered to exacerbate damage on the wet alluvial areas through four "amplification phases", all of which are integrated to produce the observed resultant damage. These phases are classified as:

$$
\begin{aligned}
& \text { primary - velocity contract between sediments and } \\
& \text { bedrock } \\
& \text { secondary - resonance of the stratigraphic (geologic) } \\
& \text { tertiary - column } \\
& \text { quaternary - height of the building (re parapet etc. type } \\
& \text { damage). }
\end{aligned}
$$

The resonance of the building (in relation to ground motion causing subsequent damage), as promoted almost universally as "the cause" by geotechnical engineers, is but only one agent of the phenomena.

The next consideration in the "cause-effect" scenario is that of liquefaction - one of nature's most common methods of reorganising the Earth's surface. There is a general misconception, not only for Newcastle, but also for other similar earthquake circumstances, that unless surface manifestations are observed (such as sand blows, sink holes etc.), this phenomenon has not occurred. Although considered as a contributor to damage in Newcastle by the Coffey study [9], the EEFIT study [36] does not make reference to liquefaction potential. Indeed, the probability of liquefaction effects in Newcastle is extremely high when one considers some specific building damage patterns (for example: at the TAFE College, Tighes Hill; Franklins Building at the western end of the CBD; settlement of bridge abutments in Newcastle; sink-hole under a church in Maitland (J. Nichols; pers. comm., 1991)) and its potential in terms of the assigned intensities, as discussed in Figure 66 and [63].

The context of this argument is vital when considering the vulnerability of urban environments in other parts of the world to the earthquake hazard based, in a large part, on the Newcastle experience. This is the basis of [36] and their inferences to the United Kingdom [78]. Extreme caution must be exercised in establishing the extent of vulnerability based on theoretical geotechnical analyses. This is clearly illustrated in the various geotechnical engineering studies published $[9,35,36,37,79]$, where estimates of amplification range from 1 to 15 , platemargin considerations are used for continental situations, selected parts of the totally available data set are used and the potential for liquefaction is not considered by some. The thesis followed in this paper to assess vulnerability considers the aspects of geology, four phases of amplification, liquefaction 
potential and the state of the building stock. Several research projects are currently in progress using this method with consideration of theoretical geotechnical aspects such as response spectra.

\section{Latent and Recurrent Defects}

Such effects as lateral and recurring defects in the aftermath of the earthquake are those most concerning the affected community. These have potential consequences for the engineering assessments, liability of builders at a future time for repair work carried out in good faith, the insurance industry, local government authorities and the public itself [18]. Indeed, this aspect is a major consideration in the future mitigation of the earthquake hazard by identifying those aspects of the built environment that now must be addressed.

In broad terms, three factors influenced these effects and the assessment thereof (based on [18]):

(a) Geographical and geological influences

- concerning the soil conditions and the geological controls on damage particularly in sedimentary terrains, which includes amplification and liquefaction

- already repaired cracks caused by the earthquake which may reappear in the future because of possible shrink/swell movements related to local weather conditions

- effect of the earthquake altering the direction of subterranean water courses which may have subsequent profound effects on foundations

- - as a result of continued ground settlement with time, recurrence of repaired defects and the emergence of new (latent) defects.

(b) Historical influences

- the built environment of Newcastle had a high proportion of brick which is non-flexible and so had a low resistance to earthquake forces

- possible effect of the mining areas causing subsidence

- architectural style of the area with parapets, awnings, chimneys and design of brick structures (both commercial and domestic) which have proven to be most susceptible to earthquake damage

- lack of structural building footings of older structures

- common style of terrace houses attached to one another (usually in rows) presenting difficulty in both repair work or demolition of a specific house without further damaging adjacent properties

- general poor standard of workmanship in the past and lack of maintenance since construction.

(c) Human influences

- relation to the insurance industry in terms of under-insured properties, the role played by loss assessors, and questionable repair costs through exploitation of and by building contractors

- inadequate keeping of records of previous damage and repairs by building contractors and local authorities which will be necessary for comparison in future defect claims and/or repairs

- use of materials (such as epoxy resins) without adequate knowledge of their long-term effects.
Reactive Clays and Shrink/Swell Conditions

In the aftermath of the Newcastle earthquake, the aspect of most concern relates to the insurance industry, specifically the unique problem of differentiating between earthquake and nonearthquake related damage. As stated by C. Henri (ICA, Sydney) in personal communication (letter) of August 27, 1991.

"The continuing flow of new and reopened claims and the various views being expressed in technical and public forums about the cause of losses and in particular the contribution of reactive clay soils is of great importance."

This refers to the possible causal relationship between latent and recurrent defects and the shrink/swell conditions of reactive clays. The connotations for the engineering, building and legal professions, in addition to the insurance industry, are of great importance both to the present recovery - renewal phase for Newcastle (and indeed other affected areas) and in the event of a future similar disaster.

The ICA commissioned a report from consulting engineers Irwin Johnston and Partners Pty. Ltd. and D.J. Douglas and Partners Pty. Ltd. [35]. Two subsequent papers, based on this commission were presented in the open literature [80, 81]. These raised geotechnical issues which, because of their importance to the understanding of and preparedness for the consequences of devastating earthquakes in the urban environment, must be clearly acknowledged. This has fortunately been achieved with numerous concerns having been raised by consulting and local authority engineers on some of the technical aspects of the arguments and inferences drawn therefrom. It is noted that these concerns in no way question the insurance industry's attitudes, (this industry is the "end-user" of the product and, thereby, has a responsibility to the community) albeit they have recognized the situation. (C. Henri, pers. comm.; August 27, 1991).

"There are many other important conclusions in the report ([35]) which deserve careful study."

To appreciate the issues, two essential conditions must be made clear from the outset. The parameter of prime interest is time. As discussed in [81], three time-frames arise:

(a) insurance policies in Australia have no cut-off period for the lodgement of damage claims as is the case in the USA and in New Zealand - hence the continuing receipt of such claims for the Newcastle earthquake;

(b) for the first few months of 1990 following the earthquake, further movement and cracking of brick buildings was observed - this is considered to be directly related to ground conditions returning to some (more stable) state of equilibrium following the earthquake;

(c) after this time ("the first few months") further distress through new minor cracking and reactivation of repaired cracks has been observed - this is the essence of all questions: is this earthquake damage, is this the shrink/swell phenomena for reactive clays, or is it a combination of both?

To ensure a sound argument, and so provide a reliable basis for inferences from the results, all available data at the time must be used in such studies. The studies above $[35,80,81]$ appear not to have satisfied this condition. 
The outcomes from these studies are vital to the insurance industry in their assessment of proximate cause, as discussed in $[80,81]$ and commissioned through [35]. In this context, it is considered that no unequivocable answer is yet available. The issues in question are highlighted in the following, noting that the debate is still very open and further research and discussion are currently in progress:

(a) Change to the ground surface:

The report [35] states that there were "essentially" no such changes in the affected area yet further states that the levelling surveys (vertical control) conducted by the government surveyors [59] found "a drop of $25 \mathrm{~mm}$ at the western end of the Newcastle CBD was the greatest ... movement ... definitely attributed to the earthquake." A study of these survey results [59] reveals that several areas showed movements which were probable results of earthquake movements - The Junction area $30-60 \mathrm{~mm}$ drop; western end of Hunter Street 10-21 mm drop (as above in the Newcastle CBD); Hexham/Sandgate (to the NW of the CBD) $20-50 \mathrm{~mm}$ drop; Glendale/Boolaroo $10-20 \mathrm{~mm}$ rise; Boolaroo/Teralba about $20 \mathrm{~mm}$ drop; note that the latter two movements amount to a $30-40 \mathrm{~mm}$ step across the postulated causative fault of [50] - albeit the absolute values are contaminated by either settlement of artificial fill or mine subsidence in some of these area. Permanent ground displacement, in terms of settlement of abutment fill, was observed at the western abutment of the Stockton Bridge, a drop of about $70 \mathrm{~mm}$ manifested in the road surface (Figure 49) and the western abutment to the Cowper Street (Carrington) Bridge, a drop of about 50 $\mathrm{mm}$ also manifested in the road surface (Figure 50).

(b) Liquefaction:

[35] states that there "is no evidence .... that liquefaction occurred ...". At the time of the earthquake it was true that no surface evidence (such as sand blows, sink holes etc) was observed. Subsequent study has shown that liquefaction probably occurred resulting in the settlement of the river banks in the cases of the bridges discussed in (a) and in some building damage (such as at the TAFE in Tighes Hill and the Franklin Building in the CBD). This is the case of the probable occurrence of liquefaction at depth and/or just below the surface and is supported by Figure 66 which concludes that liquefaction was most probable. This issue has raised a fundamental question as to the "definition" of liquefaction in terms of the geological basis and resulting surface and near- surface effects.

(c) Climate changes and the reactive clays:

It is well accepted that the predominant cause of residential dwelling damage at times of non-earthquake influences is movement in reactive clays due to climatic changes of drought and heavy rain (for example: [82]). A necessary condition is that the soils (alluvial sediments) must contain the appropriate clay minerals (smectite) that are susceptible to the reaction. Of the principal soil types (surface sediments) in the Newcastle area, those derived from the Tomago Coal Measures contain the required clay minerals while those from the Newcastle Coal Measures largely do not, and where they do occur, it is in isolated units such as the clay shales of the Australasian Seam or Dudley seam. There is a strong inference from [35] to accept the sole cause of further cracking in buildings as shrink/swell related to the climatic conditions (rainfall, number of rain days, daily temperature) from early 1989 through June 1991 and consequent soil moisture contents. Questions, however, have been raised as to the statistical treatment of the entire rainfall records for Newcastle since 1862 whereby other significant and lengthy "wet-dry" periods are also present in this data set. The question of the extent of building damage (cracking), and hence insurance claims, following these climatic conditions similar to the post-1989 earthquake period then follows. The number of claims from one insurance company (NRMA) given in [81] for the period December 1989/January 1990 through June 1991, albeit presumably of a considerable quantity, show a marked average decrease from January 1990 (several thousand immediately following the earthquake) to April- December 1990 of about 500 per month to January-June 1991 of about 150 per month. The correlation of these claims with the shrink/swell conditions is not convincing. It is considered, that for any statistical treatment to be attempted, the various states of building cracking must be considered rather than just a "total" number of claims lodged. This should include the nature of the various types of building distress (brick with cracks, timber with damage, etc.), geological conditions of sites, soil moisture contents (with time) and numbers per month when cracking occurred (or was first noticed). As it is considered in [35] that these cause and effect conditions relate primarily to the movement of building footings, a more detailed study may allow quantification of the footing movements with time - a necessary condition on which to base a cause and effect relation.

The concern in this "earthquake damage or not" argument was subsequently raised, most correctly, in a later study [80] by one of the geotechnical engineers who was co-author of the original insurance commission [35]:

"It is noted, however, that caution should be exercised in attributing all damage to this (extreme climatic conditions) cause since this has no more credence than the rationale that all damage after the earthquake was due to ongoing earthquake-induced ground movement. Each site should be treated as an individual site unless specific data is known on particular areas such that informed comment can be made rather than broad sweeping statements that are often wrong."

The complexity of this issue is abundantly clear.

Groundwater level changes:

It was stated in the commissioned report [35] that groundwater flows were not affected by the earthquake, although in the earlier report [18] the possibility was clearly considered. Again the parameter of time is important. Evidence of such changes is indeed available. Immediately after the earthquake, a marked increase in the ingress of water at five coal mines was reported (Table 5). The most serious was at Lambton Colliery where production was affected and the ingress, about six times the normal level, has continued for more than a year (G.S.Simpson, pers. comm., 1991). Probable long-term effects have occurred where seepage of water into the basement of the Tattersall's Club in Watt Street, Newcastle CBD, was observed in early 1991 (Figure 79). 
FIGURE 79

INGRESS OF WATER INTO SUBTERRANEAN BASEMENT OF CONSTRUCTION (CONCRETE SLAB) TATTERSALL'S CLUB, WATT STREET, NEWCASTLE CBD, MORE THAN ONE YEAR AFTER THE EARTHQUAKE DUE TO OPENING OF EXISTING CONSTRUCTION JOINTS AND CRACKS (ARROWS) (23.3.91; J.M.W. RYNN)

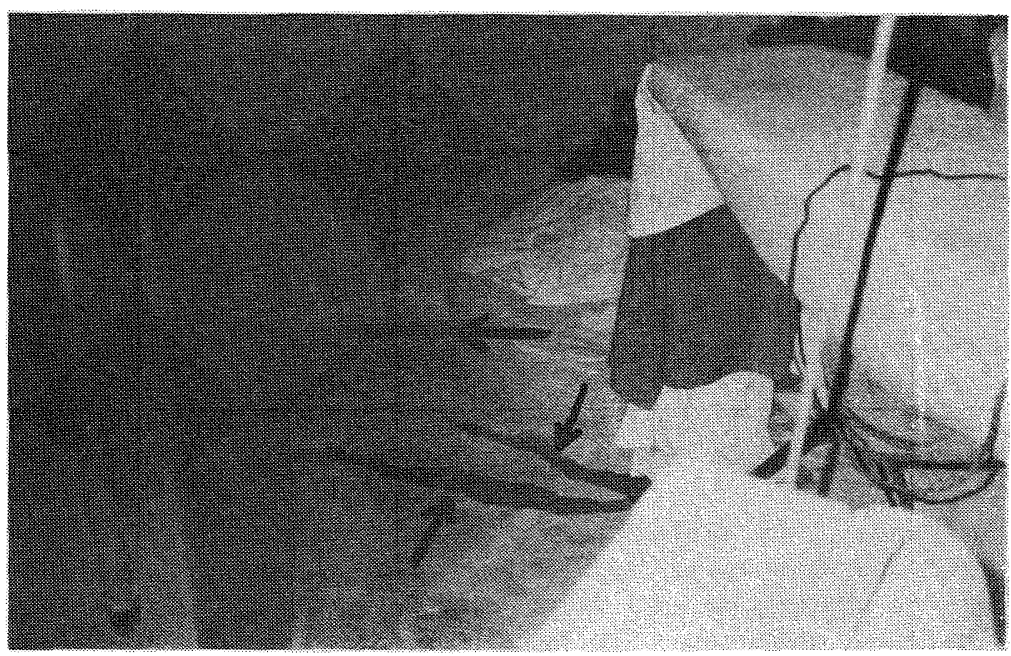

This question is also complex when the effects of tidal influences in the Hunter River estuary are considered in relation to water table movements in the adjacent (CBD) areas.

(e) Long-term ground effects:

This is the essence of the problem which has been recognised [18] in terms of ground settlement over periods of months or years. The cause is complex, undoubtedly a combination of the aforementioned effects and so difficult to provide a theoretical explanation. Comparisons with other earthquakes in the Western USA and Mexico [35] should be carefully considered and the conflicting statements therein clarified. In the Western USA, the concern has not been warranted, partly because the insurance industry has set a strict time limit on the lodgement of earthquake damage claims. The case for the Marina District of San Francisco (relative to the 1989 Loma Prieta earthquake) does, however, need closer scrutiny as to whether the earthquake accelerated ground settlement and/or was the cause of "additional" settlement over and above that normally observed in these alluvial areas. In Mexico City, particularly following the 1985 earthquake, some concern has been raised with such a problem but no definitive information has yet become available. The question appears to be one of considering "earthquake-related" perturbations on the known continuous ground movements (for example: settlement of the lake sediments in Mexico City) wherein data must be obtained both before and after an earthquake and analysed to determine any effects.

While it is considered that such shrink/swell conditions may be one of the contributing factors to long-term damage, as also noted in [18], all the above factors (a) to (e) surely indicate a complex causal relationship. These relationships need to be given much closer scrutiny to assail all interests in the quest to reconcile these latent and recurrent defects. Whatever the precise cause, or causes, preparedness for these effects in future earthquakes must be recognized by the insurance industry in their claims, by the engineering profession in future designs with explicit consideration of such geotechnical problems, and by the community to understand the limitations on insurance claims based on sound technical argument and judgement.

\section{THE LEGAL QUESTION - EARTHQUAKE DAMAGE OR NOT? [83]}

As a general principle, the issue of probable cause should be "has the earthquake caused damage to the property?" no matter what the structural adequacy of the property, and "have subsequent events exacerbated the unrepaired or improperly repaired problem?" The insurance companies have accepted to insure the property in its pre-earthquake condition and hence are responsible to reinstate the property to its pre-earthquake condition. Obviously it is advisable to enhance those items of structure if found to be inadequate, and the extra "over-cost" should be paid by the property owner and not by the insurer.

Some properties have been repaired since the earthquake, and have subsequently had recurring damage. In many of these cases, this is due to either the foundation soils on which the buildings are bearing or poor workmanship in properly repairing the property such as reinstating mortars in the masonry joints. Micro-cracking of the brickwork joints, initiated by the earthquake, may subsequently result in more obvious distress/cracking due to movements in buildings and in particular houses.

Houses are structurally very redundant with any imposed load distributed to many elements throughout the structure. The earthquake removes some of these redundancies so that the structure becomes more articulated. Thus the structure is more vulnerable to damage from the loads imposed by reactive soil, the existence of the distress at this time is due to the structure being weakened by the earthquake. Many of the houses in inner Newcastle as previously stated are quite old, and would have experienced several severe dry/wet cycles in their life, and they have not been damaged by these cyclic movements. Many other areas surrounding Newcastle which were unaffected by the earthquake have the same soil/foundation materials and there have been no (or very few) claims for repairs. The current mitigation of loss by the insurance industry, and the biased approach by certain building consultants and engineers needs to be carefully considered when assessing the insurability of property and from an ethical viewpoint. 
In a recent New South Wales (Australia) Supreme Court case, the Judge, in his ruling on the extent of liability to the insurance company, included rain damage which was caused inside the building following the earthquake and reinstatement of the building to current Codes and Local Government Ordinances as part of the earthquake damage claim. The Judge used the legal principles of the proximate cause and the application of common sense principles.

Applying those common sense principles to the facts in this case, His Honour decided as follows:

\begin{abstract}
"In my view whatever water damage occurred was caused by the earthquake. The earthquake breached the building. As a matter of common sense, rain could then be expected to enter the building and cause damage. Water entry through the damaged roof could not be prevented in the time available because it was unsafe (as a result of the earthquake damage) to erect a shelter. If, I have held, reasonable steps were taken to guard against damage so caused, but damage nonetheless occurred, it seems to me that in ordinary use of language that the damage was caused by the earthquake."
\end{abstract}

His Honour pointed out that each case must turn on its own facts and he pointed to one case where the theft of goods from a fire-affected building had been held to be a loss by fire. In another case, lightning damaged the roof of a barn and wind then tore off the rest of the roof. The Court in that case then held that the initial lightning damage made the barn more susceptible to wind damage and thus the lightning was the proximate cause of the wind damage.

It has sometimes been said that the legal concept of causation differs from philosophical and scientific notions of causation. In law, problems of causation arise in the context of ascertaining or apportioning legal responsibility for a given occurrence. The law does not accept the philosophers' definition of cause, as being the same as the conditions which are jointly sufficient to produce it. Thus, at law, a person may be responsible for damage when his wrongful conduct is only one of a number of conditions sufficient to produce that damage.

\section{POTENTIAL FOR EARTHQUAKE MITIGATION IN AUSTRALIA}

A detailed review of the potential to reduce losses from earthquakes in Australia has recently been published [7]. This was based on some lessons from the 1989 Newcastle earthquake, the historical record of earthquakes in Australia and consideration of the currently available world-wide information on both continental and plate margin earthquake situations. Such a potential is now both a realistic and achievable goal provided that a multidisciplinary approach, integrating academic research and practical experience in all associated disciplines, is shown (Figure 80).

The rare, low probability, high consequence continental earthquakes present difficult public problems, particularly the need to sustain public interest and to convince governments and relevant public sector agencies to support, both morally and financially, earthquake mitigation programmes. This is indeed the basic premise in the current United Nations International Decade of Natural Disaster Reduction (IDNDR).
Despite the Newcastle tragedy, Australia still requires a continuing awareness campaign to remind the populace of the likelihood of a probable natural disaster in the future. While the old Australian adage of "earthquakes don't happen in Australia" has gone, it has unfortunately been replaced by "it can't happen in our town." In this mitigation programme it is thus vital that all efforts continue to work through and with the national (National Disasters Organisation), regional (State Emergency Services) and local government agencies who are responsible for the community's welfare in such disasters. The four perspectives of disaster planning and management awareness, preparedness, response, recovery are paramount in this cause.

The goals for earthquake mitigation must be defined to pursue a purposeful and intense study applicable to Australia. The wealth of information and lessons from the 1989 Newcastle earthquake, together with similar international programmes in both continental (for example: Eastern USA, China) and plate-margin (for example: Western USA, New Zealand) regimes have paved the way. It is clear that for Australia, cognisance must be taken not only of potentially large earthquakes in the range ML $6.0-8.0$ but also the "moderate-sized" events with ML 5.0 - 6.0. These goals are considered in two categories:

(a) Long term goals - these are perceived to be more appropriately a national programme to improve monitoring of all earthquakes through expansion of instrumentation, geological mapping and crustal deformation studies;

(b) Short term goals - such goals, also of national priority, relate to detailed analyses of existing data to provide information for engineering requirements, insurance and emergency services agencies and community education.

Such is the direction being taken by CERA and associated organisations in their multidisciplinary research efforts.

\section{WHAT IF IT HAPPENED AT .. ANOTHER TIME AND/OR .. ANOTHER PLACE?}

The ultimate goal in earthquake mitigation is the saving of human life. All Australian cities are similar to Newcastle in their built environment and infrastructure - the only differences being that some have larger populations and others have greater industrial development. Such statistics are an important ingredient in the mitigation programme. In this context of planning for the response to and recovery from a potential earthquake disaster in the future, it is prudent to consider the scenario if the 1989 Newcastle earthquake had occurred at another time and at another place [84].

The extensive damage caused to educational institutions, hospitals, entertainment centres, emergency services buildings and other high occupancy categories is a major concern to all professionals involved in building design, construction and emergency services. The observations and damage patterns have been discussed in detail in preceding sections. The number of deaths and injuries in the context of the entire scene is thus significant. The collapse of the Newcastle Workers' Club was responsible for the nine deaths and very serious injuries therein. The falling brick debris was the direct cause of the three deaths in Beaumont Street and all of the injuries in that area of Hamilton as well as in the streets of the Newcastle CBD. 


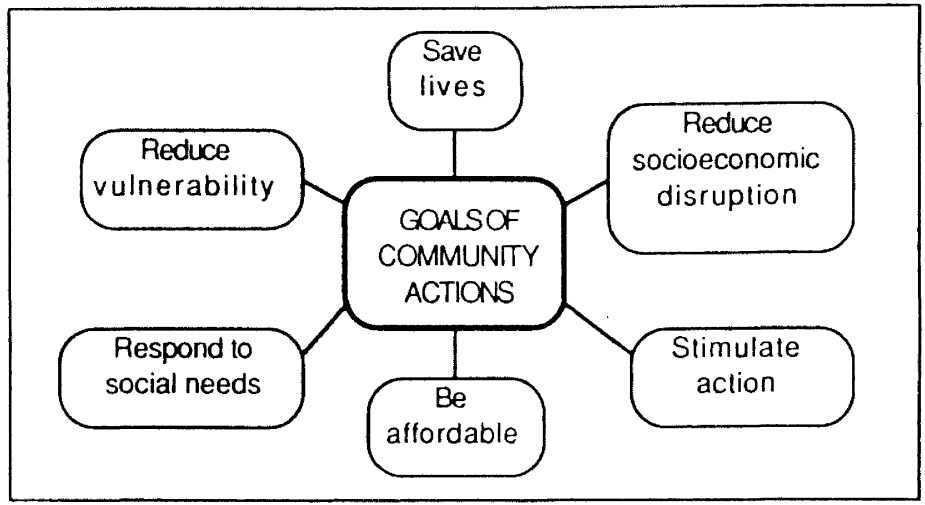

(a) Goals of community actions in implementing loss reduction measures (per W.W. Hays USGS, from [6]).

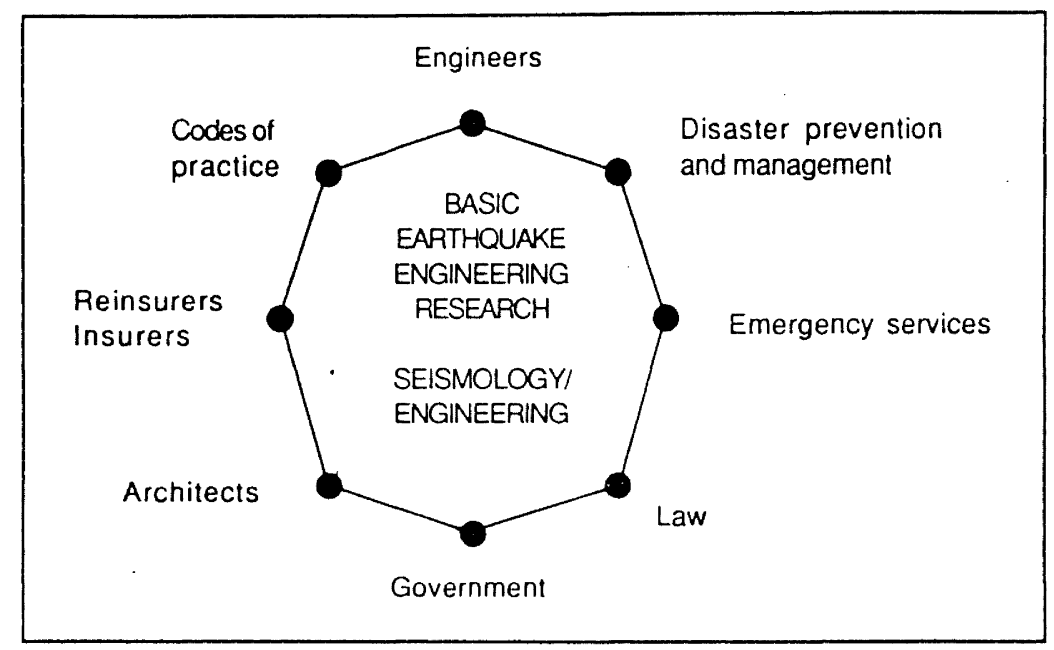

(b) The multidisciplinary approach to earthquake research in the mitigation programme

Why another time?

$\begin{array}{ll}\text { FIGURE } 80 & \text { THE DUAL APPROACH FOR THE } \\ & \text { REDUCTION OF LOSSES FROM } \\ & \text { EARTHQUAKES (FROM [7]) }\end{array}$

Consider Newcastle at 10.27am on Thursday, December 28, 1989. It was in the middle of the Australian Christmas-New Year holiday period with all schools, colleges and tertiary institutions and some $80-85 \%$ of the workforce usually employed in the region on vacation. This means that in the epicentral region (Hunter Valley region) about 165,000 people, out of an estimated population of more than 350,000 , that is about $47 \%$ of the population, were away from their normal place of attendance or employment (school, work, shopping or entertainment) when the earthquake struck.

Consider, for example, two high-occupancy situations, schools and commercial areas. At the end of the 1989 academic year, the three most severely damaged schools had enrolments of
The Junction Primary School 245

Wickham Primary School $\quad 29$

Tighes Hill TAFE College $\quad 12,200$

Plus appropriate staff for each institution.

At the time of the earthquake, there were probably no more than 100-200 persons total present at these institutions. The damage pattern at the three building complexes indicated the extent to which damage was distributed in the separate buildings and over the ground and the type of debris that became missiles. In the commercial areas, such as Hunter and Union Streets in the Newcastle CBD and Beaumont Street in Hamilton, the people movement on a normal working day would have been considerable. Again, the damage pattern and debris survey for 
the earthquake were disastrous. In addition, the damage to associated vehicles either parked in the street or parking areas would have been far more extensive.

If an identical event were to have occurred at 10.27 am on say, October 26, the following scenario can be drawn:

- damage to all buildings and services would have been similar

distribution and location of the population would have been completely different

transport system would have been fully operational the apparent "Christmas sluggishness" of the population would not have been in existence

many more of the population would have been at work, school, shopping, etc. or generally "on the streets" doing their normal weekday routines; in particular for the schools, the children would probably have been in their morning recess in the school grounds

- $\quad$ this day is also "pensioners" entitlement day.

From the inspections and studies carried out on the actual earthquake damage and considering the above aspects, the damage/injury at various locations can be estimated at this other "high occupancy - movement" time:

Anticipated number of deaths: children and students

200-300

people in the street

$300-400$

people at work

200-250

Total estimate

$700-950$

Anticipated injuries (needing treatment):

children and students

$1500-2000$

people in the street

people at work

people at entertainment venues

$2500-3500$

$2500-4000$

$300-500$

Total estimate

$6800-10000$

Whilst these figures are estimates only, they do present a realistic scenario of what may happen if such an earthquake in such an urban area was to occur during normal operations of the City. Such an unexpected event as an earthquake would have placed a major strain on all available emergency services facilities, (remembering that some of these facilities were themselves affected: for example, hospitals), to attend to the disaster.

\section{Why another place?}

Consider extending the above assumptions and estimates to Sydney on a normal working - school day with a similar Newcastle - type earthquake with its epicentre located near the Sydney CBD. To make such a judgement, several factors must be reconsidered in particular to Sydney:

- geology, population and land-use distribution in Sydney as presently established

population estimate of 3 to 4 million

- damage area of about $40 \mathrm{~km}$ radius, that is approximately the area of the County of Cumberland (i.e. greater Sydney suburban area)

building stock similar to Newcastle

- damage pattern similar to Newcastle.

With these factors, examination of a geological map of the Sydney area identifies the alluvial areas (of most vulnerability) as being
- coastal northern beaches and areas around Narrabeen Lake

- $\quad$ eastern and southeastern suburbs (Rose Bay to Botany, Kingsford, Mascot)

suburbs adjoining the Georges River and its tributaries (San Souci to Taren Point, canal estates of Sylvania Waters, Bankstown, Milperra, Liverpool and west to the Hoxton Park area)

upper reaches of the Parramatta River, around the industrial suburbs of Cabarita, Silverwater and along Duck Creek to Lidcombe

outer western suburbs (west of Blacktown to Penrith, Windsor and Richmond around the flood plains of the Hawkesbury River and its tributaries).

The estimate of damage/injury can be summaries as:

- $\quad$ area of potential severe damage to buildings about 10 times greater than Newcastle

deaths up to 3,000 persons

- $\quad$ serious injuries up to 40,000 persons

- $\quad$ insured losses about $\$ A U(1991) 10$ billion

- $\quad$ total losses about \$AU(1991)40 billion.

While these estimates of potential devastation for an ML 5.6 earthquake striking an urban area at a different time and a different place may seem staggering, it must be remembered that they are based on the effects of the all too real 1989 Newcastle earthquake and actual census statistics for Sydney.

\section{AUSTRALIA'S EARTHQUAKE CODE}

One of the ultimate aims of this earthquake related research is to provide the necessary information to implement a practical earthquake mitigation programme for the future benefit of the community. The actual earthquake forces (or ground motions) do not cause the loss of human life - it is the effect of these forces on the built environment that is the culprit. The buildings fail due to the "shaking" which is short-lived - the order of a few seconds. The consequences of failure concern not only the structural design and architectural details both internally and externally but also the foundation conditions and standards of construction and maintenance. Both new and old buildings have the potential to fail to various degrees.

The "key-link" is thus engineering - civil, structural, geotechnical, mechanical, electrical and materials. The earth sciences provide a vital and necessary input to the seismic design criteria in engineering which would be extended to the architectural and construction aspects. The application of the engineered structures is then required for the community based insurance, emergency services, local government, legal and sociological arenas. The centrepiece in this whole programme must be the building loading codes as they apply to earthquake forces.

The current Australian Earthquake Code AS2121-1979 [22] was based solely on the earthquake data available through 1976. It is well accepted that, based on the information available today there are many inadequacies and discrepancies. For the situation at Newcastle, the AS2121-1979 classification (Figure 81) is Zone Zero which is defined as "includes all areas not otherwise zoned; although significant shaking may arise in any part of this zone at some time in the future." The relevant zoning criteria states that "No shaking below (in terms of ground motion velocity) $0.050 \mathrm{~m} / \mathrm{s}$ (MM VI) is expected to cause structural damage to normal buildings and so velocities below this figure 
can be ignored." It should be noted that the constraints used in the definition of zone boundaries in AS2121-1979 were based on the latest information available from California in 1976 for "average" site conditions.
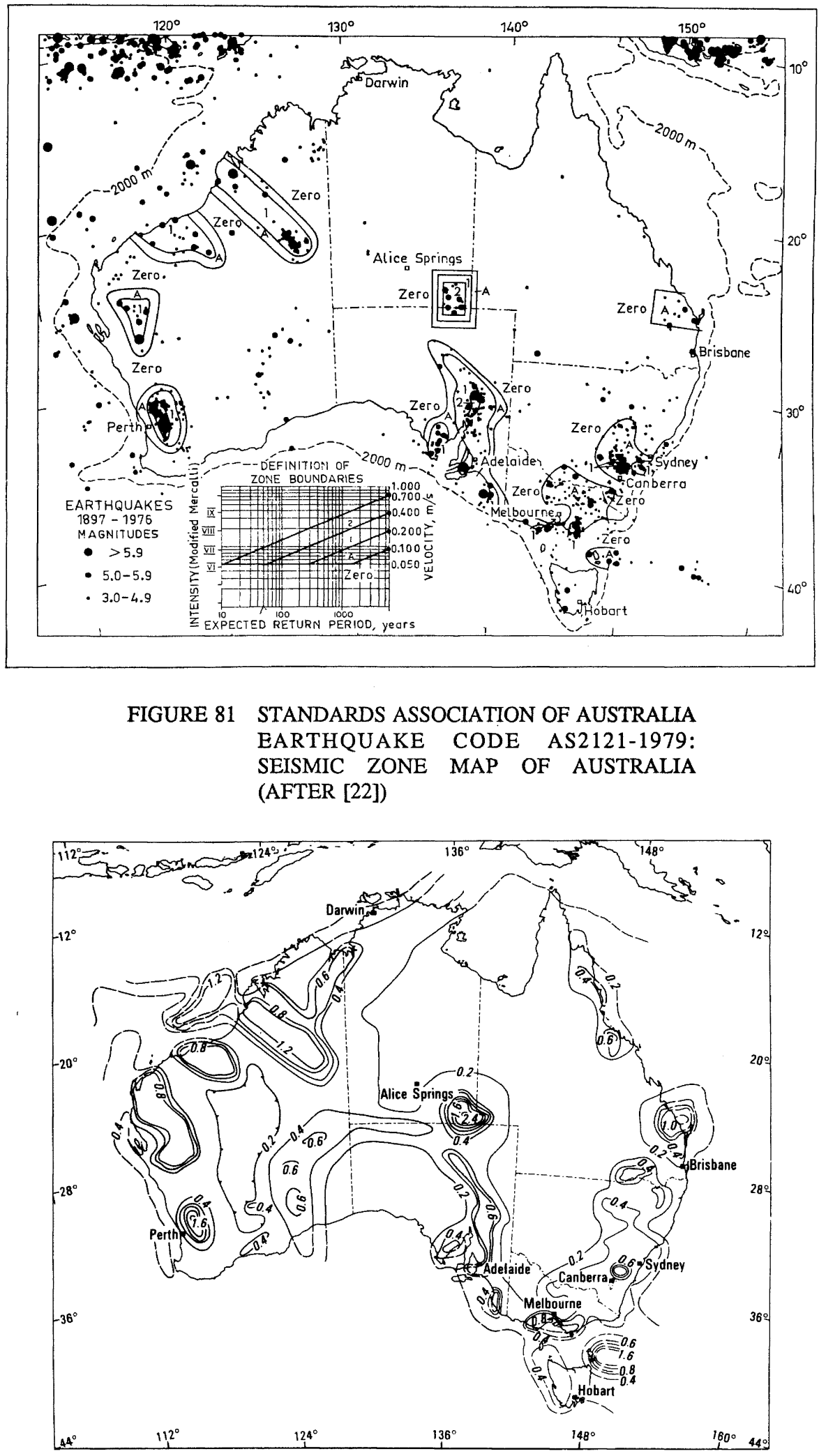

FIGURE 82 PROBABILISTIC EARTHQUAKE RISK MAP OF AUSTRALIA IN TERMS OF PEAK GROUND ACCELERATION (MSEC ${ }^{-2}$ ) WITH A $10 \%$ PROBABILITY OF BEING EXCEEDED IN A 50 YEAR PERIOD (AFTER [23]) 
In 1989 , just prior to the Newcastle earthquake, the decision was made to revise AS2121-1979 in terms of limit state format using the currently available, and obviously more extensive, earthquake data for Australia. This was to be based on the most recent probabilistic earthquake risk maps, (completed in 1986-1987 using the Australian Earthquake Data File through 1985 analysed in terms of the Cornell-McGuire method [23]) which gave estimates of peak ground motion acceleration, velocity and intensity with a $10 \%$ chance of being exceeded in a 50 year period (that is, a 1 in 500 year return period), (Figure 82).

The working premise for the revised earthquake loadings code cannot be better stated than in the "Foreword" to the current Draft Earthquake Load Code, Australian Standard DR 91094:5 (to be AS1170.4) [28]:

"The purpose of designing buildings for earthquake loads is to-

(a) minimize the hazard to life;

(b) improve the expected performance of high typeoccupancy structures as compared to ordinary structures; and

(c) improve the capability of essential facilities to function during and after an earthquake."

In an ongoing study of the need to consider earthquake design forces in Australia, the requirements necessary to formulate a revised and up-to-date code had been clearly stated [25]. These requirements, primarily, related to adopting the USA Applied Technology Council 1984 and Comite Euro-International de Baton 1987 provisions with a complete and constant analysis of all available earthquake data. The latter should yield reliable input parameters (magnitude - frequency relationships, maximum magnitude values, attenuation relationships) to determine the attenuation coefficients. Further discussion on structural engineering design standards was presented by [26].

And what of the Newcastle earthquake in this context? As stated by the Chairman of the Draft Code committee [27]:

" ... Newcastle 'quake has shown that Australia's seismicity cannot be ignored and that earthquakes should be treated as an important element in building design."

The Newcastle earthquake highlighted the "lack of consideration" of earthquake risk in this and others areas in Australia where seismic conditions were not adopted in building codes, and thus engineering design criteria, as stipulated by the Zone Zero classification of AS2121-1979. Relevant authorities sought urgent interim measures to "bridge the gap" between the inadequate provisions of AS2121-1979 and the applicability of the pending revised Code [28]. The method was to consider the most recent probabilistic seismic risk map for Australia [23] and reclassify (qualitatively) the Newcastle area to a more realistic earthquake zoning. Peak ground velocity values from this map were plotted on the current zone boundaries diagram (inset to Figure 3.1 of [22]) for various recurrence intervals and suggested a reclassification from Zone Zero to Zone A. It was noted [85] that such a method was for average sites and did not take account of the probable amplifications on the alluvial area. It also did not consider the damage observations in terms of the assigned MM intensities or the local geology.

With considerable debate about the revised Code [28] still in progress and many salient results of the 1989 Newcastle earthquake analyses still pending, extreme caution must again be exercised herein as to the use of such a "general" reclassifi- cation of earthquake zoning in the region. Concern has been expressed by engineers from the technical and socio-economic viewpoints for both new building designs and repairs to damaged buildings (retrofit). Is it relevant just to superimpose current data on the inadequate existing Code, or should a more updated and realistic approach be adopted? The cost (to the client) and necessary compliance with present building ordinances (much more stringent than were in place in the late 1970's when AS2121 was formulated) are prime factors. In view of these reservations and the knowledge of amplification and liquefaction effects on building damage, the necessity of more detailed and appropriate site specific analyses on each building site must be given a high priority.

Unfortunately, the Draft Code as it presently exists [28] fails to take adequate account of all the factors necessary. This translates into practical terms whereby not only the earthquake data (probability estimates of the hazard in terms of contour maps as in Figure 81) but also the geological conditions (both structure/tectonics and surface sediments) and engineering information must be essential input to any revised code. The 1989 Newcastle earthquake has clearly provided the latter two inputs through the building damage observed in terms of both design and the geological controls of the alluvial deposits in the region. The question of building foundations, in terms of amplification and liquefaction and thus the alluvial - structure interaction, must be addressed. It is thus mandatory that the seismologists hazard maps of [23] be suitably modified by the geological and engineering conditions particularly in relation to urban regions.

The information available from the 1989 Newcastle earthquake does provide the necessary real data input to calculate reliably the acceleration coefficients, the case for which has been presented to the Standards Australia Committee BD/6 for comment on the Draft Code [28].

\section{SUMMARY}

The earthquake hazard in Australia is ever-increasing because of rapidly expanding urbanisation and the built environment constantly increasing in age. Mitigation programmes must be implemented immediately and these must be relayed to all sections of the community, from governments to general public, to protect Australia's overall well-being. Many consequences of the 1989 Newcastle earthquake have been identified as being of great significance to urbanised areas in many other parts of the world, such as New York City and the eastern USA in general.

How could this happen in Australia? Why was the extent of devastation so large? An ML 5.6 earthquake is not considered large and was certainly not expected to wreak havoc with thirteen human lives lost and a total estimated loss of about $\$ A U(1991) 4$ billion. The evidence of damage to the built environment and the human tragedy are now real facts in our history.

The lessons that have been learnt and their application to preparedness for the future must be heeded without delay. While some of the aspects of the Newcastle earthquake are well-known in the plate-margin regions, this Australian experience has identified different problems in earthquake hazards in relation to a continental regime. Careful study of the literature revealed that similar such problems have been encountered with previous continental earthquake but, unfortunately, little notice appears to have been taken because 
these earthquakes were overshadowed by the "earthquake-prone" areas along the plate margins. The recognition of the potential of the problem by the insurance community and the current international efforts in earthquake mitigation through IDNDR attest to the importance.

The most notable aspect to be recognized from this 1989 Newcastle earthquake is the disastrous effects that can result from a moderately-sized earthquake on urban environments which contain a large proportion of old building stock. The cause-effect relationships are a natural progression from this. Cognisance must be taken of the limitations of seismology and geology, the value of macroseismic data, the geological controls of alluvial deposits on damage patterns, the geotechnical issues of amplification, liquefaction and soil factors and their influences to building foundations, engineering design criteria, construction practices and, with all these, the requirements of the emergency services, local government and socio-economic authorities.

Each aspect has specific results as outlined in the paper. The complexity of integrating all such "singular discipline" results has also been identified. The research, to date, has led to some very important questions, not the least being of a geotechnical nature involving both the immediate and long-term effects of the earthquake. Two important factors have been identified through analyses of the consequences of damage: (a) the footings of buildings which provide criteria for future construction and codification with input data from "below" by the earth sciences and from "above" by structural engineering; (b) emergency services information to provide a better preparedness for the future. These are currently being utilized in practical terms by the CERA research team through studies to produce seismic zonation maps of various urban regions along the east cost of Australia.

The responsibility of all professionals must rely heavily on the practical acceptability of Codes of Practice, certification of compliance of buildings by those who build them (i.e. the building contractors), with the technical requirements of the building codes and codes of ethics [86,87]. In the context of learning from the 1989 Newcastle earthquake experience, one vital element is that of consideration of the vulnerability of modern urban environments to earthquakes of the same, and indeed larger, magnitudes. For this, analyses of all available data must be promulgated, and not only the use of some selected set of the data to reestablish supposed validity of some theoretical premise that has existed for many years. Inferences from the analyses must be carefully scrutinised. The nature of the earthquake hazard, the requirements of relevant and complete input information for the revision of the Australian Earthquake Code, and the necessity to minimize the loss of human life in future disastrous earthquakes, demands this multidisciplinary approach to understand the earthquake hazard.

\section{ACKNOWLEDGMENTS}

The research reported in this paper has been made possible through the kind support and assistance given by Alderman John McNaughton (Lord Mayor of the City of Newcastle), Superintendent Russell Cook (formally Chief Superintendent, Newcastle, New South Wales Police) and Senior Sergeant John Hopgood (Leader of the Queensland Government Task Force, Queensland Police Service). Contributions to the programme and to this research paper have come from innumerable sources and it suffices to specifically acknowledge Inspector T. Collins, Inspector I. Park and Senior Sergeant E. Riggs (Newcastle Police Department), Commodore C. Littleton (Natural Disasters Organisation, Australia), Mr R. Barchard and Mr L. Bickford (Queensland State Emergency Service), Mr W.Boyce (Kinhill Cameron McNamara), Mr C.Featherstone (Munich Reinsurance), Mr G. Simpson (Maunchest Pty. Ltd.), Professor I. Plimer (formally University of Newcastle), Dr K. Moelle (University of Newcastle), the citizens of the Newcastle region and throughout the State of New South Wales, the Newcastle "Herald", Dr R.Chung (National Academy of Sciences, USA), Dr A. Johnston (CERI, Memphis State University, USA), Dr K. Jacob (Columbia University, USA), and Dr B.Carss and Ms S. Brown (Continuing Professional Education, The University of Queensland). The draft of this paper was kindly reviewed by Dr J.Fenwick (Queensland State Department of Transport), Dr D. Williams (The University of Queensland) and Professor R. Park (University of Canterbury, Christchurch, New Zealand).

\section{REFERENCES}

1. Advisory Committee on the International Decade for Natural Hazard Reduction, "Confronting Natural Disasters: An International Decade for Natural Hazard Reduction", Washington, D.C., National Academy Press, 1987.

2. Rynn, J.M.W. (Ed.), "2-1-2 Conference", Proceedings of the Fourth Earthquake Engineering Conference, The University of Queensland, Departments of Geology and Mineralogy and Civil Engineering Publication, Brisbane, 12-16 November, 1990.

3. Rynn, J.M.W. (Ed.), "What We Have Learnt From The Newcastle Earthquake", Proceedings of the Conference by The Newcastle City Council and Centre for Earthquake Research in Australia, The University of Queensland Continuing Professional Education Publication, Newcastle, 24-25 October, 1991.

4. Littleton, C., "What Have We Learnt?" The Macedon Digest, Vol 6, No 4, p 12, Summer 1991/92.

5. Rynn, J.M.W., "The Potential to Reduce Losses from Earthquakes in Australia", In D.I. Smith and J.W. Handmer (Eds.) "Australia's Role In The International Decade For Natural Disaster Reduction", The Australian National University Centre For Resource and Environmental Studies, Resource and Environmental Studies No.4, pp 9-21, 1991.

6. Hamilton, R.M. and Johnston, A.J., "Tecumseh's Prophecy: Preparing for the Next New Madrid Earthquake", U.S. Geol. Sur. Circ. 1066, 30 pp, 1990. 
7. Earthquake Engineering Research Institute, Proceedings of the "Fourth International Conference on Seismic Zonation", Volumes I - III, Stanford University, California, USA, 25-29 August, 1991.

8. Melchers, R.E. (Ed.), "Conference on the Newcastle Earthquake". Proc. of Conf., 15-17 February 1990, Newcastle, Australia, The Institution of Engineers, Australia, National Conference Publication No.90/15, 155 pp, May 1990.

9. Melchers, R.E. (Ed.), "Newcastle Earthquake Study", The Institution of Engineers, Australia, publication, 155 pp, June 1990.

10. Newcastle City Council, "Post Earthquake Assessment of Building Damage", Internal Report prepared by H.J. Stuart, 14 March 1990.

11. McCue, K., Wesson, V. and Gibson, G., "The Newcastle, New South Wales, Earthquake of 28 December 1989", Bureau of Mineral Resources Journal of Geology and Geophysics, Vol 11, 559-567, 1990.

12. Walker, G.R., "Interim Report on Newcastle Earthquake", CSIRO, Australia, Division of Building, Construction and Engineering Report DBCE Doc. 90/01(s), 14 pp, January 1990.

13. Rynn, J.M.W., "The Passive Continental Margin of Eastern Australia - The Myth Shattered by the 1989 Newcastle Earthquake: The Need for More Realistic Earthquake Risk Estimates", Proceedings of the Pacific Rim Congress 90, Gold Coast, The Australasian Institute of Mining and Metallurgy, Vol.3, pp 679-685, May 1990

14. Brennan, E., "Urban Geology and Its Relationship to Intraplate Earthquake Risk - Lessons from the 1989 Newcastle Experience", Proceedings of the Pacific Rim Congress 90, Gold Coast, The Australasian Institute of Mining and Metallurgy, Vol 3, pp 687698, May 1990.

15. Blong, R., Walker G., Berz, G., Griffiths, N. and Scott, P., "The Newcastle Earthquake '89", Munich Reinsurance Company of Australia, 40 pp, June 1990.

16. Tiedemann, H., "Newcastle: The Writing on the Wall", Swiss Reinsurance Company, Switzerland, 85 pp, 1990.

17. Public Works Department, NSW, "Newcastle Earthquake, 28 December, 1989 - Buildings and Facilities Damage Costs and Programme for Restoration", NSW Government, 28 pp, May 1990.

18. Jubelin, K., "Newcastle Earthquake - Examination of Recurrent and Latent Defects", Report of Special Committee of the Newcastle Master Builders Association to the NSW Government, 24 pp, October 1990.

19. Waller, K.M., "Findings Newcastle Earthquake Disaster of the 28th December, 1989", Report of the New South Wales State Coroner, 25 pp, July 1990.
20. The Hunter Valley Research Foundation, "Economic Effects of the 1989 Earthquake", Report prepared for Citycentre Newcastle, 10 pp, November 1990.

21. Miles, T., "1989 Newcastle Earthquake - Health Effects", Report by the Faculty of Medicine, The University of Newcastle, February 1990.

22. Standards Association of Australia, "AS2121-1979 Earthquake Code (The Design of Earthquake Resistant Buildings)", 96 pp, November 1979.

23. Gaull, B.A., Michael-Leiba, M.O. and Rynn, J.M.W., "Probabilistic Earthquake Risk Map of Australia", Aust. Jour. Earth Sci., Vol 37, pp 169$187,1990$.

24. Rynn, J.M.W. and Boyce, W.H., "Earthquake Risk Assessment and Engineering Design - A Vital Consideration for the Pacific Rim", Proceedings of the Pacific Rim Congress 87, Gold Coast, The Australasian Institute of Mining and Metallurgy, pp 729 - 735, August 1987.

25. Boyce, W.H., "Earthquake Design Loads For Australia?" Proceedings of The Institution of Engineers, Australia, Structural Engineering Conference, Adelaide, pp 296 - 299, October 1990.

26. Melchers, R.E., "Earthquake Design Standards For Australia", Department of Civil Engineering and Surveying, The University of Newcastle, Research Report No.058.01.1981, 20 pp, 1991.

27. Woodside, J., "New Quake Code", Engineering World, pp 30-34, October, 1991.

28. Standards Australia, "Draft Australian Standard DR 91094:5, Minimum Design Loads on Structures Part 4: Earthquake Loads" (To be AS1170.4), April 1991.

29. Loke, J.Y.O., "Preparing for Tomorrow's Earthquake", Proceedings of the Local Government Engineers Association Annual Conference, pp 68-74, 1991.

30. Morgan, A.R., "Newcastle Earthquake - The Aftershocks", Australian Insurance Institute Journal, Vol 14, No.3, pp 6-10, July 1991.

31. Rynn, J.M.W., "Earthquake - The Australian Experience", Proceedings of The Association of Risk and Insurance Managers of Australia 1991 Conference, Brisbane, pp 135-156, November 1991.

32. Eastoe, B., "Newcastle and Region Status Report", Renewal Co-ordination Unit, Newcastle City Council, June 1991.

33. New Zealand National Society For Earthquake Engineering, "13. Special Session - Newcastle Earthquake", Proceedings of the Pacific Conference on Earthquake Engineering, Auckland, Vol.2, pp 327365, November 1991. 
34. Brunsdon, D.R., "The December 28, 1989 Newcastle, Australia Earthquake", Bull. NZNSEE, Vol. 23, No.2, pp 102-120, June 1990.

35. Brunsdon, D.R., Forbes, J.G. and Douglas, D.J., "Factors Influencing the Structural Behaviour of Residential Buildings in Newcastle Following the December 1989 Earthquake", Report to the Insurance Council of Australia, Sydney, by Irwin Johnston and Partners and D.J. Douglas and Partners, 56 pp, July, 1991.

36. Chandler, A.M., Pappin, J.W, and Coburn, A.W., "Vulnerability and Seismic Risk Assessment of Buildings Following the 1989 Newcastle, Australia Earthquake", Bull. NZNSEE, Vol. 24, No.2. June 1990.

37 Pappin, J.W., Chandler, A.M. and Coburn, A.W., "The 1989 Newcastle Australia Earthquake - A Field Report by EEFIT", Earthquake Engineering Field Investigation Team, Institution of Structural Engineers, London 36 pp, March 1991.

38. The Hunter Valley Research Foundation and Newcastle City Council, "Newcastle and The Hunter Region Year Book 1990", 72 pp. 1989.

39. Hunter, C., "Earthquake Tremors Felt in the Hunter Valley Since White Settlement", Hunter House Publications, Newcastle, 120 pp. 1991.

40. Rynn, J.M.W., Denham, D., Greenhalgh, S., Jones, T., Gregson, P.J., McCue, K.F. and Smith, R.S., "Atlas of Isoseismal Maps of Australian Earthquakes Part 2", Bureau of Mineral Resources, Canberra, Bulletin 222, 1987.

41. Rynn, J.M.W. and Hunter, C., "Earthquake History of the Newcastle and Hunter Valley Regions, Australia - A Valuable Resource for Earthquake Mitigation", submitted to the Australian Journal of Earth Sciences, 1991.

42. Everingham, I.B., McEwin, A.J. and Denham, D., "Atlas of Isoseismal Maps of Australian Earthquakes", Bureau of Mineral Resources, Canberra, Bulletin 214, 1982.

43. Coppersmith, K.J., "Seismic Science Characterisation for Engineering Seismic Hazard Analyses", in Earthplate Engineering Research Institute Proceedings of "Fourth International Conference on Seismic Zonation, Stanford University, California, USA, Vol 1, pp 3-60, 1991.

44. Bowman, J.R. and Davey, J.W., "Relocation of Teleseismically Recorded Earthquakes Near Tennant Creek, Australia: Implications for Midplate Seismogenesis", J. Geophys. Res., Vol 96, No.B7, pp 11973-11979, 1991.

45. McGregor, P.M. and Ripper, I.D., "Notes on Magnitude Scales", Bureau of Mineral Resources, Canberra, Record 1976/56 (unpublished).
46. Johnston, A.C., "An Earthquake Strength Scale For The Media And Public", Earthquakes and Volcanoes, in press, 1991.

47. Brune, J.N., "Tectonic Stress and Spectra of Seismic Shear Waves From Earthquakes", Bull. Seismo. Soc. Amer., Vol 81, No.1, pp 81-98.

48. Hanks, T.C. and Kanamori, H., "A Moment Magnitude Scale", Jour. Geophys. Res., Vol 84, No.B5, pp 2348-2350, 1979.

49. Johnston, A.C., "The Stable Continental Region Earthquake Data Base", in K.J. Coppersmith, A.C. Johnston, L.R. Kanter, R.R. Youngs and A.C. Metzger, "Methods for Assessing Maximum Earthquakes in the Eastern United States", Electric Power Research Institute, EPRI Report RP-2556-12, Chapter 3, 1991.

50. Gibson, G., Wesson, V. and McCue, K., "The Newcastle Earthquake Aftershock and its Implications", in R.E. Melchers (Ed.), Proceedings of the "Conference on the Newcastle Earthquake", The Institution of Engineers, Australia, National Conference Publication No.90/15, pp 14-18, 1990.

51. Moelle, K.H.R., "A Geological Picture of the Newcastle Earthquake Area - This is not a Newcastle Fault; Or Is It?" in J.M.W. Rynn (Ed.), Proceedings of The Newcastle City Council and Centre For Earthquake Research In Australia Conference "What We Have Learnt From The Newcastle Earthquake", The University of Queensland Continuing Professional Education Publication, Newcastle, 24-25 November, 1991.

52. Department of Mines, New South Wales, 1:250,000 Geological Series Sheets SI 56-2 NEWCASTLE (First Edition) and SI 56-5 SYDNEY (Third Edition), 1966.

53. Stewart, E. and Barnes, R., "The Newcastle City Council Experience", Paper presented in Workshop at The Association of Risk and Insurance Managers of Australia National Conference, Brisbane, 11 November 1991.

54. Public Works Department, New South Wales Government, Hunter and New England Regional Office, "Newcastle Earthquake 28 December, 1989, NSW, NSW Government Buildings and Facilities Damage Costs and Programme for Restoration", 28 pp, May 1990.

55. Eiby, G.A., "The Modified Mercalli Scale of Earthquake Intensity and its Use in New Zealand", N.J.J. Geol. Geophys., Vol 9, No.1/2, pp 122-124, 1966.

56. Rynn, J.M.W., "Commentary On Seismic Risk Estimates and Related Uncertainties for Northeastern Australia", Department of Geology and Mineralogy, The University of Queensland, Special Paper, 1989.

57. Berz, G., "Natural Disasters and Insurance and Reinsurance", Earthquakes and Volcanoes, Vol 22. No.3, pp 99-102, 1991. 
58. Jacob, K., "Seismic Hazards and the Effects of Soils on Ground Motions for the Greater New York City Metropolitan Region", Proceedings of the Continuing Education Seminar of the NYC Metropolitan Section of the ASCE, New York City, 13-14 November, 1990.

59. O'Kane, P.G., "Newcastle Earthquake Surveys", Proceedings of the 33rd Australian Survey Congress, Albury, Paper 26, April 1991.

60. Rynn, J.M.W. and Brennan, E., "The 21 February 1991 ML 2.0 Fingal, NSW, Earthquake - Geological Controls for Severe Shaking on Marine Alluvials", submitted to the Australian Journal of Earth Sciences, 1992.

61. Gutenberg, B. and Richter, C.F., "Earthquake Magnitude, Intensity, Energy And Acceleration", Bull. Seismological Society of America, Vol 32, No.3, 1942.

62. Wang, J., Wei, P and Wu, X., "Comparative Study of the Characteristics of Seismic Waves Recorded Down Hole and on Ground", Acta Seismologica Sinica, Vol 2, pp 379-389, June 1989.

63. Williams, D.J., "The Potential for Liquefaction", In J.M.W. Rynn (Ed.) Proceedings of the 2-1-2 Conference, Fourth Earthquake Engineering Workshop, Brisbane, The University of Queensland, Continuing Professional Education, November 1990.

64. Tuttle, M.P., Sieber, L. and Bradley, L., "Liquefaction of Glaciaomarine Sediments During the 1727 Earthquake in Newburyport, Massachusettes", In K.H. Jacob, (Ed.) Proceedings from the Symposium on Seismic Hazards Ground Motions, Soil-liquefaction and Engineering Practice in Eastern North America, National Center for Earthquake Engineering Research, Buffalo, Technical Report NCEER-87-0025, pp 467479, October, 1987.

65. Pedersen, I.S., "Behaviour of Structures - Major Commercial Buildings", in R.E. Melchers (Ed.) Proceedings of the "Conference on the Newcastle Earthquake", The Institution of Engineers, Australia, National Conference Publication No. 90/15, pp 21-25, 1990.

66. Pedersen, I.S., "The Newcastle Earthquake Structural Problems Discovered", Paper presented to the Building Science Forum, Sydney, Australia, 1990 (unpublished).

67. Page, A.W., "Who Is Responsible for the Design and Construction of Masonry?" Civil College Technical Report, Engineers Australia, pp 1-3, September 1990.

68. Page A.W., "Quality Control in Masonry Construction - The Lessons from the Newcastle Earthquake", in J.M.W. Rynn (Ed.) "What We Have Learnt from the Newcastle Earthquake", Proceedings of the Conference by The Newcastle City Council and Centre for Earthquake Research in Australia, The University of Queensland Continuing Professional Education Publication, Newcastle, 24-25 October 1991.
69. Stuart, H., "The Newcastle Earthquake - Seismic Hazard Mitigation of Existing Buildings:, in J.M.W. Rynn (Ed.) "What We Have Learnt From The Newcastle Earthquake", Proceedings of the Conference by The Newcastle City Council and Centre for Earthquake Research in Australia, The University of Queensland Continuing Professional Education Publication, Newcastle, 24-25 October 1991.

70. Park, I., "The Immediate Response and Rescue", in J.M.W. Rynn (Ed.) "What We Have learnt From The Newcastle Earthquake", Proceedings of the Conference by The Newcastle City Council and Centre for Earthquake Research in Australia, The University of Queensland Continuing Professional Education Publication, Newcastle, 24-25 October 1991.

71. Lester, L., "Insurance Aspects of the 28 December 1989 Newcastle Earthquake", in J.M.W. Rynn (Ed.) Proceedings of the 2-1-2 Conference, Fourth Earthquake Engineering Workshop, Brisbane, The University of Queensland, Continuing Professional Education, November 1990.

72. Henri, C.D., "Believe It Or Not - The Insurance Industry is also Learning", in J.M.W. Rynn (Ed.) "What We Have learnt From The Newcastle Earthquake", Proceedings of the Conference by The Newcastle City Council and Centre for Earthquake Research in Australia, The University of Queensland Continuing Professional Education Publication, Newcastle, 24-25 October 1991.

73. Rynn, J.M.W., "Earthquake - The Australian Experience", Proceedings of The Association of Risk and Insurance Managers of Australia 1991 Conference, Brisbane, pp 135-156, November 1991.

74. Simpson, G.S., "Newcastle, The Lucky City ... Now ... ", in J.M.W. Rynn (Ed.) "What We Have learnt From The Newcastle Earthquake", Proceedings of the Conference by The Newcastle City Council and Centre for Earthquake Research in Australia, The University of Queensland Continuing Professional Education Publication, Newcastle, 24-25 October 1991.

75. Morgan, A., "The Iceberg Factor - What Loss Adjusters and Insurers Have Learnt from the Newcastle Earthquake", in J.M.W. Rynn (Ed.) "What We Have learnt From The Newcastle Earthquake", Proceedings of the Conference by The Newcastle City Council and Centre for Earthquake Research in Australia, The University of Queensland Continuing Professional Education Publication, Newcastle, 24-25 October 1991.

76. Staveley, J.K., "Earthquake Insurance in Australia", Abstract of paper presented at the Earthquake Engineering Symposium, Sydney, 2-3 December 1986, The Institution of Engineers, Australia, National Conference Publication No.86/15, pp 48-52, December, 1986.

77. Bentero, V.V. (Ed.), "Lessons Learned from the 1985 Mexico Earthquake", Earthquake Engineering Research Institute Publication 89-02, 264 pp, December 1989. 
78. Pappin, J.W., "Earthquake Engineering in Regions of Low Seismicity", Bull. NZNSEE, Vol.24, No.4, pp 317-332, December 1991.

79. Poulos, H.G., "Relationship Between Local Soil Conditions and Structural Damage in the 1989 Newcastle Earthquake", The Institution of Engineers, Australia, Civil Engineering Transactions, CE33, 3, pp 181-188, July, 1991.

80. Douglas, D.J., and Carr, R.J., "Movement of the Ground - Don't Blame it all on the Earthquake", in J.M.W. Rynn (Ed.) "What We Have learnt From The Newcastle Earthquake", Proceedings of the Conference by The Newcastle City Council and Centre for Earthquake Research in Australia, The University of Queensland Continuing Professional Education Publication, Newcastle, 24-25 October 1991.

81. Brunsdon, D.R., "The Aftermath of the Newcastle Earthquake", in Proceedings of the Pacific Conference on Earthquake Engineering, NZNSEE, Vol.3, pp 285296, November 1991.

82. Cameron, D.A., and Walsh, P.F., "Damage to Buildings on Clay Soils", CSIRO Division of Building Research, Melbourne, Australia, Technical Bulletin 5.1, $24 \mathrm{pp}$, November 1984.

83. Martin, M.G., "The Pitfalls of Litigation", Paper presented at The Insurance Institute of New South Wales Earthquake Seminar, Newcastle, 1991 (unpublished).

84. Hughes, P.R., "What If It Happened On 26 October? What If It Happened in Sydney?", in J.M.W. Rynn (Ed.) "What We Have learnt From The Newcastle Earthquake", Proceedings of the Conference by The Newcastle City Council and Centre for Earthquake Research in Australia, The University of Queensland Continuing Professional Education Publication, Newcastle, 24-25 October 1991.

85. Michael-Leiba, M. and Gaull, B., "Earthquake Hazard in the Newcastle Area, NSW, Australia", in R.E. Melchers (Ed.), Proceedings of the "Conference on the Newcastle Earthquake", The Institution of Engineers, Australia, National Conference Publication No. 90/15, pp 146-148, 1990.

86. Varghese, R., "Certification", in J.M.W. Rynn (Ed.) "What We Have learnt From The Newcastle Earthquake", Proceedings of the Conference by The Newcastle City Council and Centre for Earthquake Research in Australia, The University of Queensland Continuing Professional Education Publication, Newcastle, 24-25 October 1991.

87. Hughes, P.R., "Codes and Certification - A Users Viewpoint", in J.M.W. Rynn (Ed.) "What We Have learnt From The Newcastle Earthquake", Proceedings of the Conference by The Newcastle City Council and Centre for Earthquake Research in Australia, The University of Queensland Continuing Professional Education Publication, Newcastle, 24-25 October 1991. 